Rev. Biol. Trop. 46(4): 961-1031, 1998

www.ucr.ac.cr www.ots.ac.cr www.ots.duke.edu

\title{
Orchid florula of Parque Nacional Manuel Antonio, Quepos, Costa Rica
}

Franco Pupulin

Research Associate, Marie Selby Botanical Gardens. Research Associate, Jardín Botánico Lankester, Universidad de Costa Rica. Permanent address: Via della Libertà 17, I-21051 Arcisate (VA), Italy

Received 4-VI-1998. Corrected 31-VIII-1998. Accepted 10-IX-1998.

\begin{abstract}
An orchid florula of Parque Nacional Manuel Antonio, Costa Rica, is provided on the basis of collections made in 91 plots within the park and field observations carried out in the neighbouring areas; 39 species belonging to 25 genera are recorded. Orchid species are described and a key to the species for field identification, based on vegetative features, is provided. Analytical drawings are provided for 35 of the taxa considered. Ecological notes and estimate of frequency for each species within the Park are given. A new orchid species, Lockhartia pandurata, is described and illustrated.
\end{abstract}

Key words: Orchidaceae, Taxonomy, Frequency, Tropical wet forest, Costa Rica, Parque Nacional Manuel Antonio.

The Parque Nacional Manuel Antonio (PNMA) constitues a relict of the Pacific, coastal wet forest in Costa Rica and a unique sample for the country of transitional life zone between tropical wet and tropical very wet forests (Tosi 1969, Holdridge 1982). In spite of its reduced size, PNMA plays a significant role as an educational center, having one of the highest rates of visits of the whole Costa Rican park system both by local and foreign visitors. A first attempt to classify floristic and faunistic components of PNMA was done in 1983 (Bolaños et al.), but more specific studies are needed in order to understand the actual richness of the protected area. The hope of the present paper, intended to clarify the diversity of the orchid familiy at PNMA, is to represent a first step for a systematic revision of the Park flora.

\section{MATERIALS AND METHODS}

Study area: The PNMA covers an area of 683 ha along Costa Rican central Pacific coast in the province of Puntarenas, about $175 \mathrm{~km}$ southwest of San José $\left(9^{\circ} 21^{\prime}-9^{\circ} 25^{\prime} \mathrm{N}\right.$ and $84^{\circ} 06^{\prime}-84^{\circ} 10^{\prime} \mathrm{W}$ ) (Bolaños et al. 1983, Campos et al. 1983). The national park is characterized by low hills and irregular topography, with altitudinal range varying from sea level to about $150 \mathrm{~m}$. Rainfall average per year is $3,287 \mathrm{~mm}$. Rainy months are from June through November, and the dry season extends from December to May (Rojas et al. 1983). Average temperature is $26.2{ }^{\circ} \mathrm{C}$, with $21^{\circ} \mathrm{C}$ and $32^{\circ} \mathrm{C}$ minumum and maximum respectively. According to Rojas et al. (1983), the vegetation of PNMA may be subdivided in the following units: primary forest (105 ha), disturbed primary forest (130 ha), secondary forest (122 ha), young secondary forest (228 ha), secondary forest with fruit trees (6 ha), mangrove (18 ha), pasture (47 ha), grassy lagoon (14 ha), and rock islands (13 ha) (Fig. 1). A slightly modified vegetation map of the central area of PNMA was done by Wong Reyes (1990). For the purpose of the present 


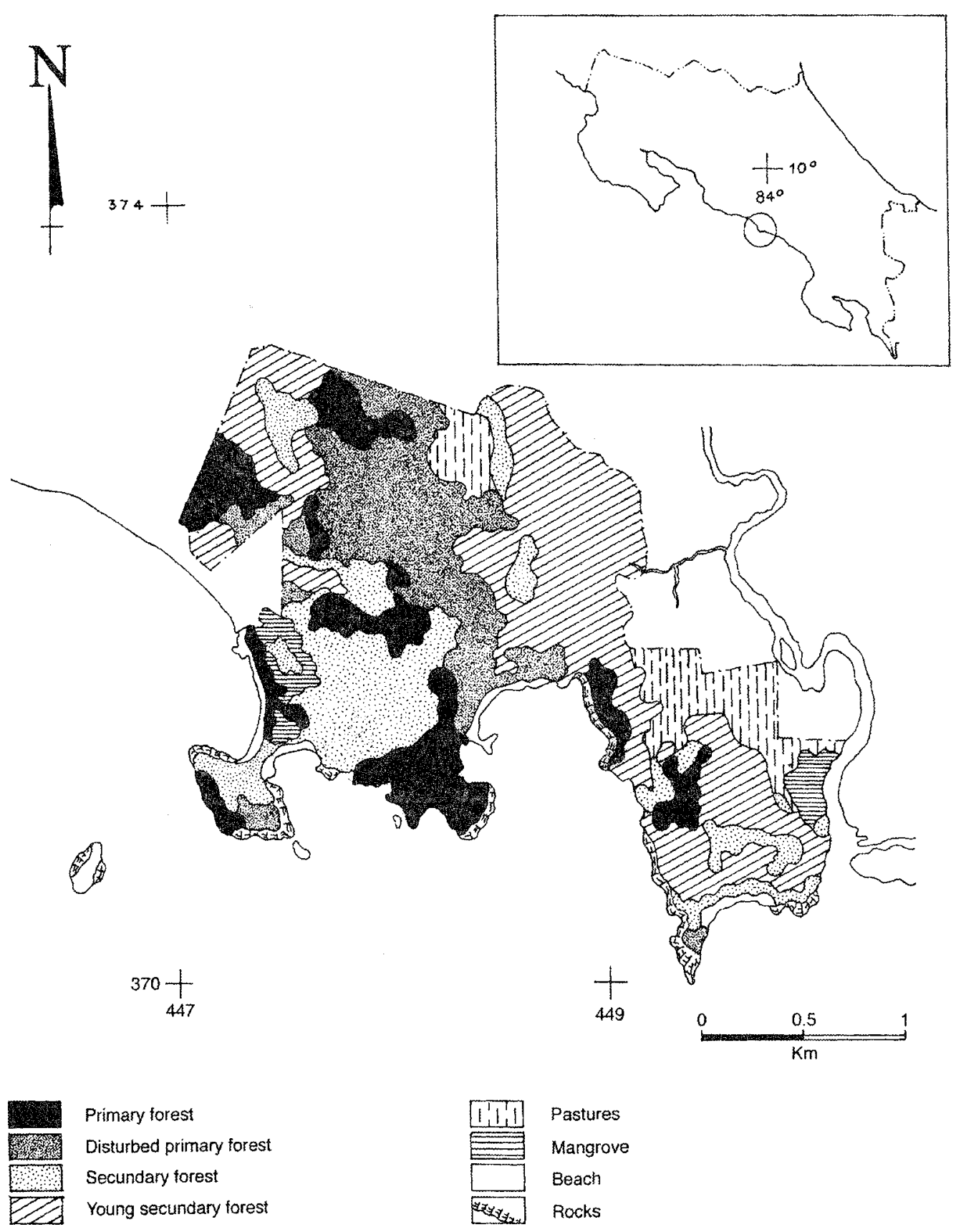

Fig. 1. Vegetation units of the park. 
study six unis were sempled. Beach vegetation was inclubec in secondary mature forest. Pastures were sampled through relictual trees, that in some cases host a consistent epiphytic flora due to their age.

A total of 346 species of vascular cryptogams and angiosperms has been reported for PNMA (Boza 1986). A preliminar list of Orchidaceae, comprising 33 species in 23 genera, was done in 1983 (Bolaños et al.). However, apporentedly no collections were made at that time, and no orchid material from this area is conserved either at the Herbario Nacional de Costa Rica (CR), the Herbarium of the Escuela de Biologia, Universidad de Costa Rica (USJ), or at the Instituto de Biodiversidad in Heredia (INB). Only two specimens determined as Lockhartia micrantha from Manuel Antonio and Punta Quepos, both collected outside the Park, are kept at USJ and CR.

Methods: The present list of orchid species is based upon collections gathered by the author during the months of June to August 1995. Collections were made in 91 plots $(100$ $\mathrm{m}^{2}$ each) of tropical wet, transition to tropical very wet forest at PNMA, at intervals of about $10 \mathrm{~m}$ between 0 and $150 \mathrm{~m}$ a.s.l. (Fig. 2). Species that were not collected at PNMA but found by the author in natural populations in lowlands and hills around the Park are also included and marked in the key with an asterisk (*). The distance from PNMA is less than 5 kilometers, and many of the taxa found at the Park form natural populations in these areas. Distribution of the plots resulted as follows: 17 in primary forest $(18 \%), 14$ in disturbed primary forest $(16 \%), 30$ in secondary forest $(33 \%)$, of which 8 plots in beach vegetation, 22 in young secondary forest (24\%), 1 in secondary forest with fruit trees $(1 \%)$, and 7 isolated trees in pasture $(8 \%)$. Within each plot orchid species were visually determined, and two to three samples for each apparentedly different taxon were collected, together with additional data about vegetational aspects. Sexual material was identified, and sterile material was cultivated and flowered in Italy for identification. Costa
Rican major herbaria were revised for orchid material from the studied and neighbouring areas. Nomenclature follows Dressler (1993). Collections are deposited at the Herbarium of the Escuela de Biologia, Universidad de Costa. Rica (USJ), whereas duplicates are kept at the Herbario Nacional de Costa Rica (CR) and the Marie Selby Botanical Gardens (SEL).

\section{RESULTS}

The Orchidaceae constitute the largest family at PNMA, followed by Graminae and Leguminosae with about 25 and 23 species respectively (Bolaños et al. 1983). 39 orchid species, pertaining to 25 genera have been recorded. The genera richest in species are Epidendrum (6 species) and Maxillaria (4 species), reflecting the very high number of species within these genera all over the country (Mora-Retana \& Garcia 1992, Dressler 1993). For each of the 39 orchid species frequency at PNMA has been assessed and classified. Species occurring in 25 or more $100 \mathrm{~m}^{2}$ plots are considered "very common". Species present in 14 to 24 plots are classified as "common". Taxa recorded in 6 to 13 plots are considered "frequent". Those found in 2 to 5 plots are regarded as "occasional". Species observed in 1 plot, or only recorded from outside the Park area, are considered to be "rare". Distribution of total number of species over frequency classes is shown in Fig. 3. "Very common" species include Epidendrum amparoanum (44), Catasetum maculatum. (35), Scaphyglottis stellata (31), and Brassavola nodosa (26). "Common" species include Dimerandra emarginata (21), Epidendrum congestum (21). Caularthron bilamellatum (15), and Lockhartia pandurata (16). "Frequent" species include Epidendrum stamfordianum (6), Maxillaria neglecta (8), M. ponerantha (7), Nidema ottonis (6), and Pleurothallis corniculata. (9). "Occasional" and "rare" species account for nearly $60 \%$ of total species within the study area. 


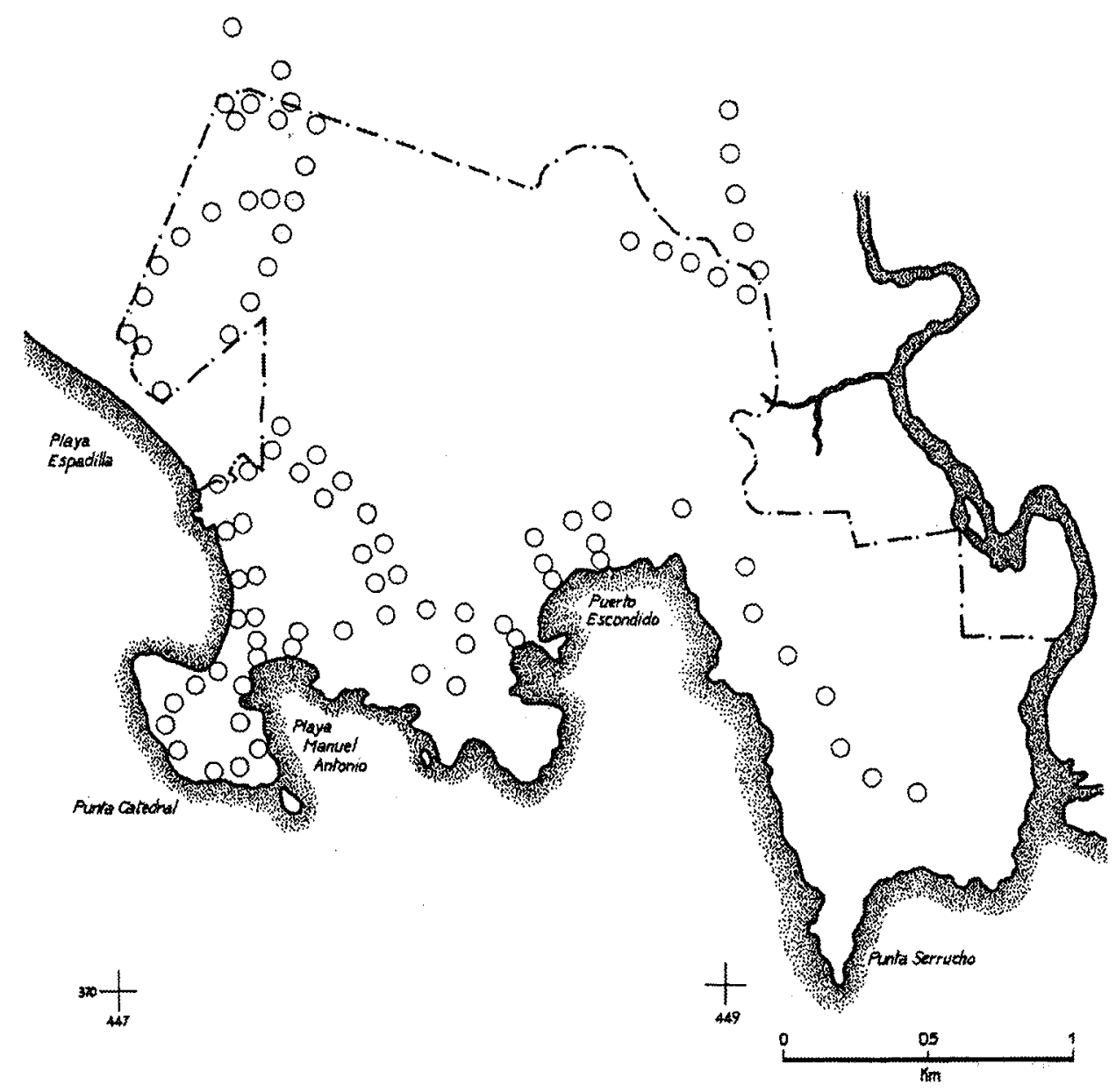

Fig. 2. Ubication of the plots within the study area. 


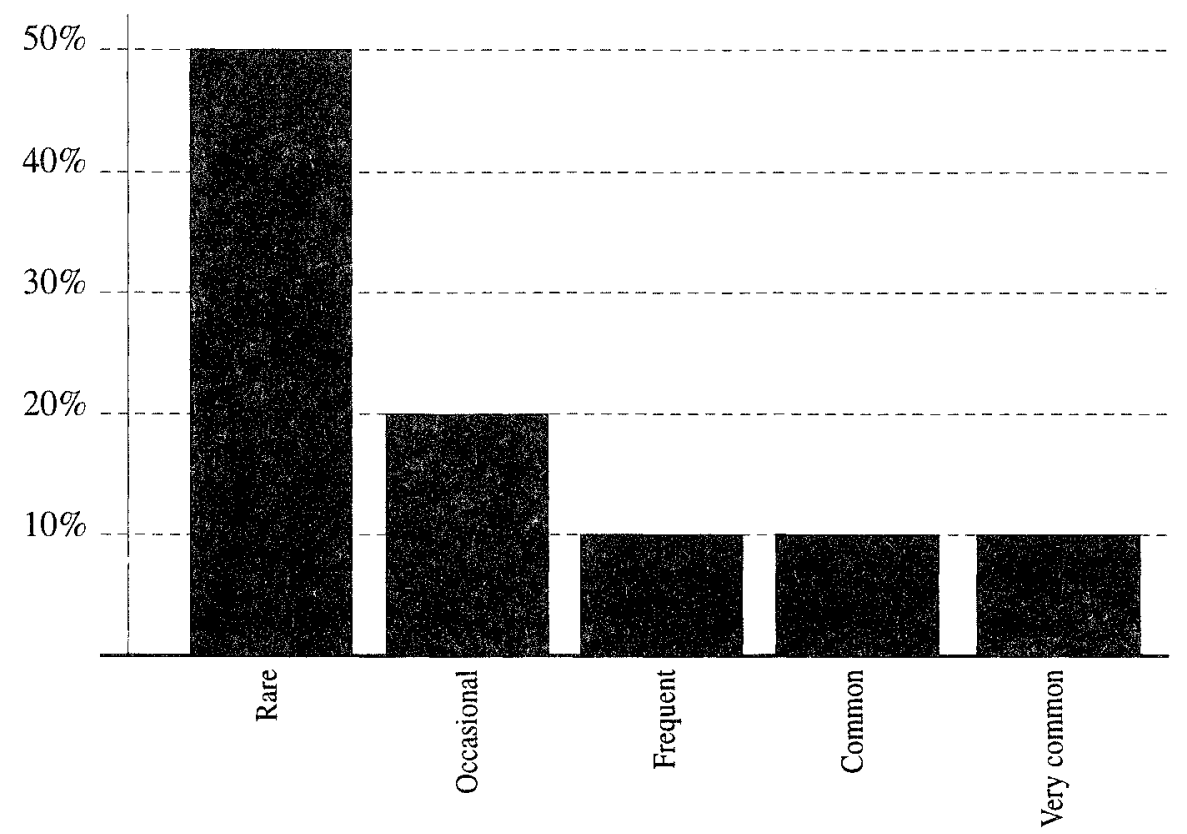

Fig. 3. Distribution of total number of species over frequency classes.

Distribution and number of orchid taxa within the different types of vegetations strongly confirms the importance of conservation of pristine habitats. Orchid diversity is highest in primary forest, decreasing towards young secondary forest and beach vegetation (Fig. 4). Among the thirteen plots where no orchid species were observed, ten plots pertained to secondary and young secondary vegetation units. On the contrary, all the five plots where the highest number of orchid species was found (10 to 8 orchid species per plot) were located in primary and disturbed primary forest.

\section{DISCUSSION}

The distribution of six species proved to be restricted to primary undisturbed forest, and this figure raises to eight when also the plots of disturbed primary forest are included. However, it is interesting to note how a number of orchid species are also restricted to secondary forest (six species) or young secondary forest (four species) (Fig. 5). It is likely the restriction of taxa distribution in young secondary forest reflects preferences of some orchid species for disturbed habitats. Ionopsis satyrioides (Sw.) Rchb.f. and Leochilus scriptus (Scheidweiler) Rchb.f., as well as members of the genera Notylia and Trizeuxis, are known to be early colonizers of young canopies, and strong ecological evidences were offered to explain site preferences for the obligate twig epiphytes (Chase 1987). Notwithstanding, plots in young secondary forest were relatively poor in orchid taxa, and more than twenty species are found elsewhere in the Park except in the areas covered with young secondary vegetation (Fig. 5).

The puzzle of different vegetation units within the Park also reflects on its orchid flora. Species distribution within plots established in different vegetation units supports the view of strongly ecological preferences for many of the orchid populations found at PNMA. Three main groups may be identified. A first group is represented by orchid species that form large populations in all types of vegetation, with a general preference for moderately to completely exposed epiphytic situations. This group includes common orchids like 

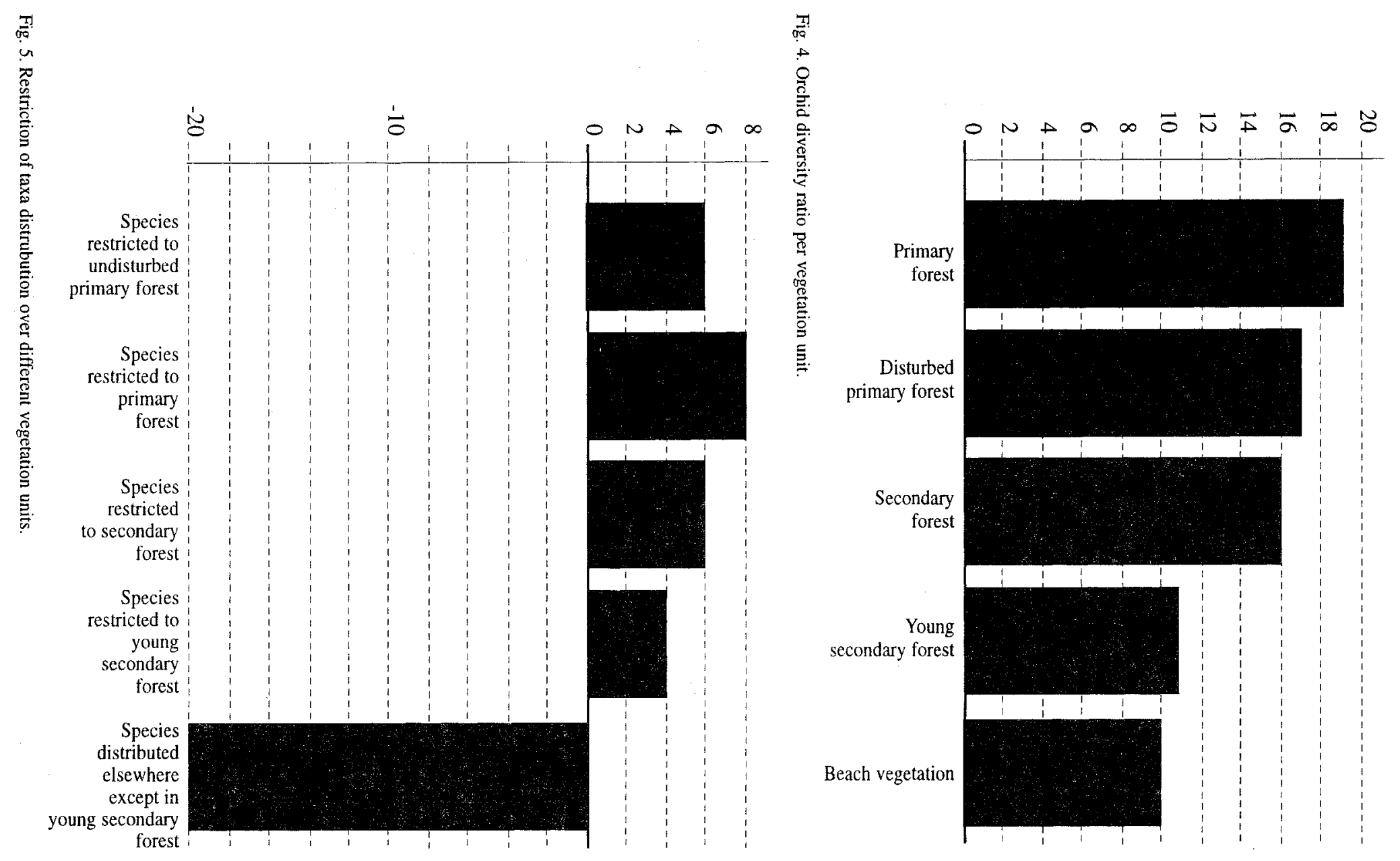
Brassavola, Catasetum, Caularthron, Dimerandra, some Epidendrum and Maxillaria species, Nidema, and Scaphyglottis, all of them widespread along Pacific lowlands from southern Mexico to Colombia. A second group is composed by orchid species restricted to the remnants of primary or secondary mature forest, like Aspasia, Dichaea, Epidendrum stamfordianum, Lockhartia, Maxillaria ponerantha, Oncidium spp., Pleurothallis, Sobralia, Stenorrhynchos, Trigonidium, and Vanilla. Though some of the taxa within this group are of wide distribution in Mesoanerica, it also includes species supposedly endernic of Costa Rican central Pacific lowland forests. Most of these species are shade tolerant epiphytes, mainly established on trunks and large axes of the phorophytes, where thick layers of bryophytes prevent complete dessiccation of the substrate and the roots during the dry season. Along the borders of PNMA I found representatives of a third group of orchids, mainly composed by specialized twig epiphytes, including Bulbophyllum, Campylocentrum, Ionopsis, Leochilus, Notylia, Polystachya and Trizeuxis. All of these orchids are rarely or only occasionally found in the park. Seed morphology (Chase 1997, Chase \& Pippen 1988) and stress tolerance of juvenile twig epiphytes enabled them to establish and survive in the harsh conditions of young canopies and isolated trees in severely disturbed and anthropic habitats. Jeopardized vegetation with scattered phorophytes (e.g. orchard trees, trees in pastures, palm trunks, bushes along roadsides) support this way the dispersal of specialized members of the Orchidaceae that are progressively integrating the orchid stock of the original forests.

\section{KEY TO THE SPECIES}

1. Plant terrestrial ........Stenorrhynchus lanceolatum *

1. Plant epiphytic .............................................. 2
2 (1). Leaves cylindric (subterete to terete) ……............ 3

2. Leaves flattened ...............................................

3 (2) Pseudobulbs cylindric, more than $3 \mathrm{~cm}$ long ........... Brassavola nodosa

3. Pseudoblbs rounded, very reduced, less than $1 \mathrm{~cm}$

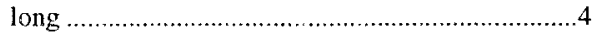

4 (3). Plants usually less than $10 \mathrm{~cm}$ long. lonopsis satyrioides *

4. Plants usually more than $50 \mathrm{~cm}$ tall (to $1 \mathrm{~m}$ ) Oncidium ascendens

5 (2). Leaves laterally flattened.

5. Leaves dorsoventrally flattened ............................. 7

6 (5). Stems elongated, plants braidlike Lockhartia pandurata

6. Stems short; plants fanlike..........Trizeuxis falcata *

7 (5). Plants with pseudobulbs .8

7. Plant without pseudobulbs.................................. 27

8 (7).Pseudobulbs arising from top of old pseudobulbs, forming chains

8. Pseudobulbs arising from base of old pseudobulbs, not forming chains ................................................... 10

9 (8).Pseudobulbs pyriform, wider near the base Scaphyglottis stellata

9. Pseudobulbs cylindric, not wider near the base ....... Scaphyglottis prolifera *

10 (9).Leaves scattered along pseudobulb. 11

10. Leaves (1-2) terminal on pseudobulb .13

11 (10) V. Inflorescence lateral.......Catasetum maculatum 11. Inflorescence terminal .................................... 12

12 (11).Pseudobulbs solid. Polystachya foliosa*

12. Pseudobulbs hollow .........Caularthron bilamellatum

13 (10). Pseudobulbs monophyllous .................................

13. Pseudobulbs 2 -leaved at apex ..............................18

14 (13). Plants cespitose (rhizome very short) ..............15

14. Plants with pseudobulbs scattered on a long rhizome. 17

15 (14).Inflorescence pendulous..................Notylia pittieri

15. Inflorescence erect ..............................................16

16 (15).Inflorescence lateral .................eochilus labiatus

16. Inflorescence terminal ......................... Nidema ottonis

17 (14). Inflorescence erect.............Maxillaria oreocharis

17. Inflorescence pendulous ...........Maxillaria neglecta 
18 (13). Pseudobulbs at less three times longer than wide......19

18. Pseudobulbs not more than two times longer than wide ...21

19 (18). Pseudobulbs of a single internode Encyclia abbreviata

19. Pseudobulbs of more than one internode 20

20 (19) Pseudobulbs less than $10 \mathrm{~cm}$ long; inflorescence terminal Scaphyglottis micrantha

20. Pseudobulbs more than $20 \mathrm{~cm}$ long; inflorescence from the rhizome at the base of pseudobulb Epidendrum stamfordianum

21 (18). Basal leaves (cataphylls) present .22

21. Basal leaves (cataphylls) absent Maxillaria crassifolia

22 (19). Plant pendent

23 (22).Plant small, about $5 \mathrm{~cm}$ tall

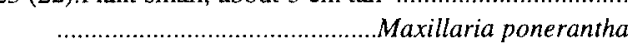

23. Plant more than $15 \mathrm{~cm}$ tall. . .24

24 (23). Pseudobulbs club shaped. Aspasia epidendroides

24. Pseudobulbs not club shaped. .25

25 (24)Pseudobulbs widely elliptic, very flat.

...................................... Oncidium stenobulbon *

25. Pseudobulbs ovate, sulcate, not flat Oncidium polycladium *

26 (21).Inflorescence erect ......Trigonidium egertonianum 26. Inflorescence pendent .......Bulbophyllum oerstedii *

27 (7) Plant a vine Vanilla pompona *

27. Plant not a vine 28

28 (27). Single leaf on each stem

28. Leaves several on each stem

29 (28). Leaf coinlike, rounded, flat on the bark Pleurothallis lewisae

29. Leaf lanceolate, not flat on the bark Pleurothallis corniculata

30 (29). Leaves distinctly pleated............. Sobralia decora

30. Leaves not pleated .......................................... 31

31 (30). Inflorescence terminal ............................... 32

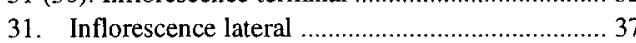

32 (31). Plant with thickened stem

Dimerandra emarginata

32. Plant with slender stem .33

33 (32). Stem less than $5 \mathrm{~cm}$ long, completely concealed by the base of the leaves
33. Stem more than $15 \mathrm{~cm}$ long ............................ 34

34 (33). Stem with 4-6 leaves only at apex

Epidendrum noc

34. Stem ...............................Epidendrum nocturnum

35 (34). Base of the leaves completely envolving the stem Epidendrum amparoanum

35. Base of the leaves only partially envolving the stem. 36

36 (35). Leaves elliptic, obtuse, fleshy

Epidendrum sculptum

36. Leaves lanceolate, acute, not fleshy

Epidendrum isomerum *

37 (31). Inflorescence 1-flowered. Dichaea panamensis *

37. Inflorescence many-flowered ......................... 38

38 (37). Stem less than $20 \mathrm{~cm}$; leaves about $4 \mathrm{~cm}$ long.... Campylocentrum micranthum

38. Stem more than $30 \mathrm{~cm}$ long $(50 \mathrm{~cm}$ ):

leaves about $8-10 \mathrm{~cm}$ long Campylocentrum panamense *

\section{LIST OF SPECIES}

\section{ASPASIA Lind'.}

Cespitose, epiphytic herbs with 1-2 leaved pseudobulbous stems. Leaves subcoriaceous at apex of the pseudobulb and along the stem. Inflorescence a lateral many-flowered, often successive, spicate raceme. Flowers rather large and showy, greenish-brown stripped with brown. Sepals and petals subequal, free: lip with a claw entirely adnate to the column and a broad lamina with several keels. Column erect, nearly terete, footless, wingless. Pollinia 2.

A genus of about 6 species native of Central and South America.

1. Aspasia epidendroides Lindl., Hook. Jour. Bot. 1: 6. 1834. Aspasia fragrans $\mathrm{Kl}$., Ind. Sem. Hort. Bot. Berol.12. 1852. Odontoglossum aspasia Rchb.f., Walp. Ann. 6: 851. 1861. (Fig. 6).

Plant epiphytic, medium sized, to $35 \mathrm{~cm}$ tall, with terete rhizome and rather spaced pseudobulbs. Roots fleshy, with green vegetative apex. Pseudobulbs diphyllous, 

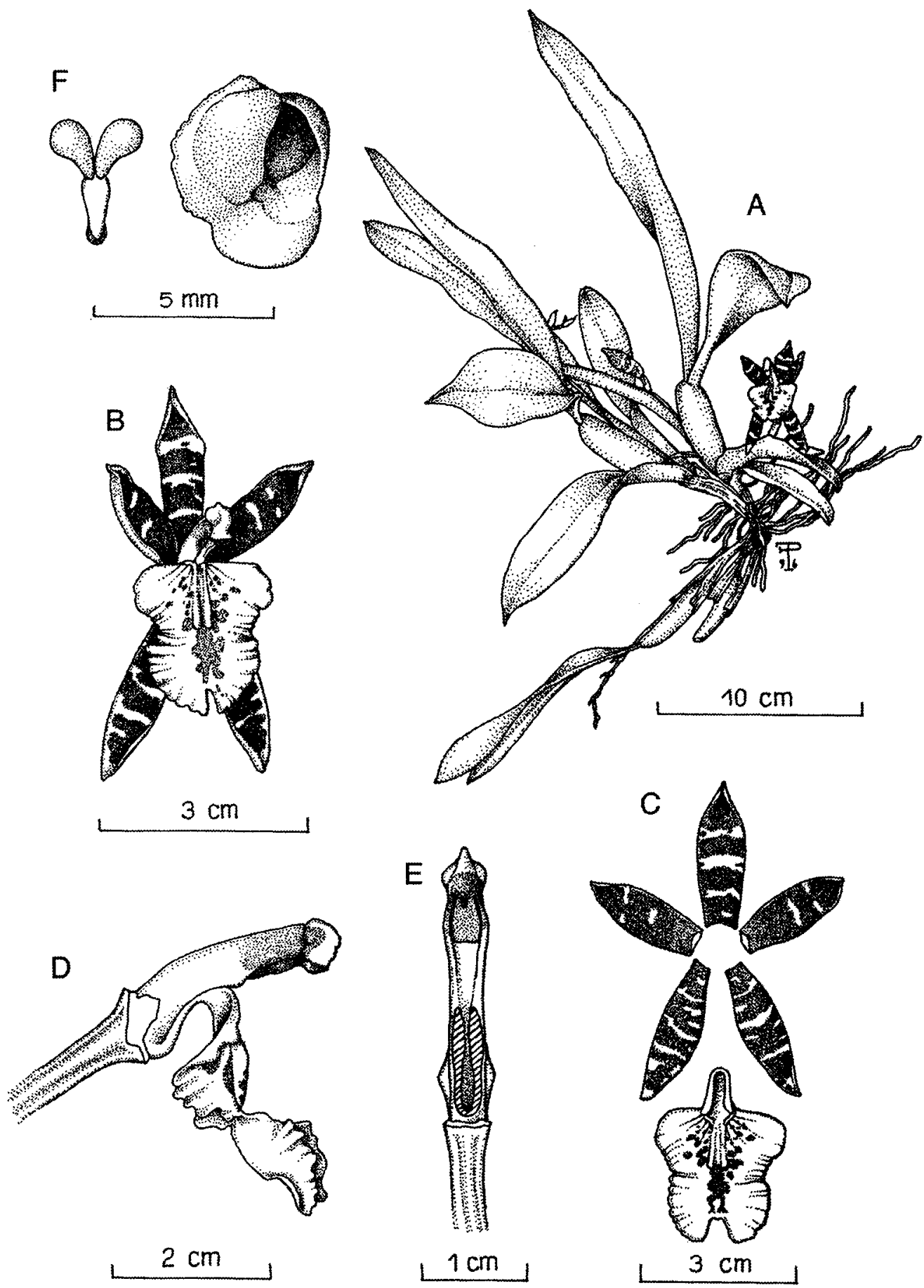

Fig. 6. Aspasia epidendroides Lindl. A - Habit. B - Flower. C - Column and lip, lateral view (sepals and petals removed). D - Dissected perianth. E - Column, ventral view. F. Pollinarium and operculum. Illustration voucher: F Pupulin 311. 
stipitate, oblong-elliptic to linear-elliptic, iaterally compressed, $5-12 \mathrm{~cm}$ long, 3-6 cm wide, the cylindric lower portions covered with several imbricating bracts, the uppermost 2 or 3 foliaceous. Leaves elliptic-lanceolate, subcoriaceous, acute, up to $24 \mathrm{~cm}$ long, $2.5-5 \mathrm{~cm}$ wide. Inflorescences 1-2 simple, erect, fewflowered racemes, to $18 \mathrm{~cm}$ long, produced from the axils of the uppermost foliaceous bracts; bracts ovate-lanceolate, about $1 \mathrm{~cm}$ long. Flowers showy, scented, the sepals green with broad transverse brown bands, the petals pale lavender to grenish with transverse bars, the lip white with conspicuous lavender markings and a yellow callus, the column tinged with lavender. Sepals elliptic to elliptic-obovate, acute, obscurely apiculate, to $2.8 \mathrm{~cm}$ long, $0.9 \mathrm{~cm}$ wide, the lateral sepals often reflexed. Petals ellipticobovate, concave, obscurely keeled at the dorsal apex, to $2.1 \mathrm{~cm}$ long, $0.9 \mathrm{~cm}$ wide. Lip clawed, to $3 \mathrm{~cm}$ long, $2.4 \mathrm{~cm}$ between the lateral lobes; the claw adnate to the lower portion of the column, about $8 \mathrm{~mm}$ long, the subquadrate, obscurely 3-lobed lamina abruptly deflexed, the midlobe emarginate with undulate margins, the disk with 2 parallel extending from the base to the insertion of the midlobe. Column semiterete, basally adnate to the lip, to $2.3 \mathrm{~cm}$ long. Pollinia 2 , obpyriform, on a short ligulate stipe; visciudium elliptic. Anther cap hemiglobose, keeled.

Distribution: From Guatemala to Panama. Widespread but not common at low elevations in Central America.

Parque Nacional Manuel Antonio: Epiphytic on lower branches and trunks of trees mainly in primary or mature secondary forest. Plants are usually found in shaded conditions. Occasional at PNMA.

Phenology: flowering mainly occurs in August-September. It may also flower from February to April.

\section{BRASSAVOLA R. Br.}

Cespitose, epiphytic or lithophytic herbs with terete, monophyllous pseudobulbs and conduplicate to terete, linear leaves. Inflorescence a terminal or lateral 1 - to manyflowered raceme. Flowers large and conspicuous, white. Sepals and petals subequal, free; lip with a tubular claw enfoding the column and a broad lamina. Column very short, footless, winged. Pollinia 8.

A neotropical genus of about 17 species.

1. Brassavola nodosa (L.) Lindl., Gen. et Sp. Orch. Pl. 114. 1831. Epidendrum nodosum L., Sp. Pl. 953, 1753. Brassavola venosa Lindl., Bot. Reg. 26: Misc. 20, 1840. Brassavola scaposa Schltr., Orchis 13: 77, 1919. (Fig. 7).

Plant epiphytic, medium sized, up to 50 $\mathrm{cm}$ tall, with short, terete rhizome. Roots fleshy, with green to brownish vegetative apex. Pseudobulbs terete to clavate, slender, 2.5 to $8.5 \mathrm{~cm}$ long, about $0.6 \mathrm{~cm}$ wide, covered by 2 3 scarious, tubular sheaths, monophyllous. Leaf conduplicate, very fleshy-coriaceous, linear, acuminate to slightly mucronate, sulcate above, up to $20 \mathrm{~cm}$ long, $0.9-1.2 \mathrm{~cm}$ wide. Inflorescence terminal, to $13 \mathrm{~cm}$ long, 1- to many-flowered (mainly 2-fowered); peduncle terete; bracts triangular-lanceolate, acute, 0.7-1 $\mathrm{cm}$ long. Flowers large and showy, with pale green sepals and petals, and white lip spotted by pale purple at the base. Sepals subequal, linear-lanceolate, acute, to $9 \mathrm{~cm}$ long, $0.6 \mathrm{~cm}$ wide. Petals linear, attenuate, to $8.1 \mathrm{~cm}$ long, $0.4 \mathrm{~cm}$ wide. Lip with a tubular claw, abruptly expanding into a ovate-cordate lamina, apiculate at apex, to $7.8-8 \mathrm{~cm}$ long, $4.3 \mathrm{~cm}$ wide at mid-point of the lamina; claw about 3 $\mathrm{cm}$ long, $1.2 \mathrm{~cm}$ wide, with erose-dentate margins. Column short, with a pair of triangular-subfalcate, acute wings, 3-lobed at apex, to $7 \mathrm{~mm}$ long. Pollinia 8 , in two subequal groups of 4, on two powdery, bilobed caudicles. Anther cap hemiglobose, 8-celled.

Distribution: From Mexico to Panama and northern South America. Common at lower elevations on Pacific coasts in Central America.

Parque Nacional Manuel Antonio: Epiphytic on Hippomane mancinella 


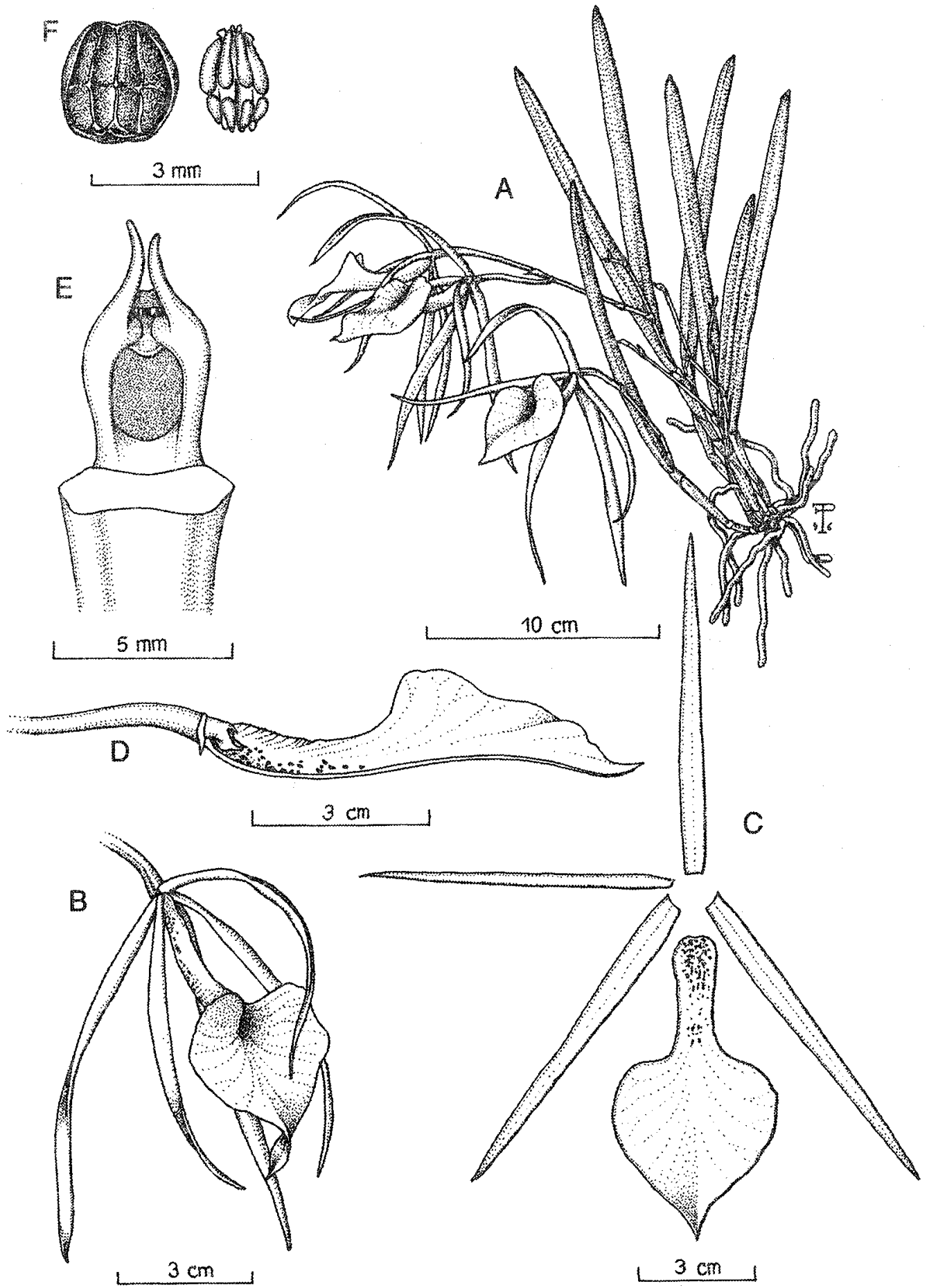

Fig. 7. Brassavola nodosa (L.) Lindl. A - Habit. B - Flower. C - Column and lip, lateral view (the lip longitudinally sectioned, sepals and petals removed). D - Dissected perianth. E - Column, ventral view. F. Operculum and pollinaria. Illustration voucher: F. Pupulin 331. 
(manzanillo), Tabebuia rosea (roble de sabana), Cocos nucifera and, less frequently, on Terminalia catappa (almendro de playa) trees just to the line of seashore. Also epiphytic in mangrove vegetation on Rhizophora sp. Plants of $B$. nodosa are usually growing in exposed to medium-shaded conditions. White color of the flowers without any nectar guide and smell at night are characters generally associated to pollination by sphingid moths. However, the actual pollinator of the species is still unknown. Very common at PNMA.

Phenology: flowering mainly occurs in July-August.

\section{BULBOPHYLLUM Thouars}

Epiphytic herbs, usually with 1-2 leaved pseudobulbs. Leaves subcoriaceous at the apex of pseudobulbs. Inflorescence lateral from the base of the pseudobulb, a spike, raceme and rarely a single flower, sometimes thickened or widely flattened. Flowers often with a mimicry and colours intended for flies pollination. Dorsal sepal free, the laterals often connate and adnate to the column foot; petals usually smaller than sepals, variously ornate; lip thin or rigid, usually fleshy, articulated to the column foot. Column erect, auriculate, forming a foot at the base. Pollinia 4 .

A pantropical genus, mainly Asiatic, of about 1,000 species.

\section{Bulbophyllum oerstedii (Rchb.f.)}

Hemsley, Biol. Centr-amer. 3: 213. 1883. Bulbophyllaria oerstedii Rchb.f., Bonpl. 3: 223. 1855. Bulbophyllum pachyrhachis Auct., non Grisebach. (Fig. 8).

Plant epiphytic, medium sized, up to 20 $\mathrm{cm}$ tall. Roots filiform, glabrous. Pseudobulbs subconical, strongly 4 -angulate, slender, 2.5 to $4 \mathrm{~cm}$ long, about $2.5 \mathrm{~cm}$ wide, widely spaced on a creeping rhizome, covered at the base by 2-3 scarious, tubular sheaths, diphyllous. Leaves coriaceous, linear-lanceolate, acute to acuminate, up to $20 \mathrm{~cm}$ long, $1-2.5 \mathrm{~cm}$ wide. Inflorescence lateral, arching to pendent, many-flowered, the peduncle slender, becoming fleshy at the rhachis, $12-25 \mathrm{~cm}$ long; bracts broadly triangular, acute, $0.3 \mathrm{~mm}$ long. Flowers small and inconspicuous, subsessile, born in shallow depressions on the rhachis, pale green to yellowish green finely spotted with purple; lip purple at apex. Dorsal sepal free, concave, ovate, acute, $6 \mathrm{~mm}$ long, $3.5 \mathrm{~mm}$ wide. Lateral sepals ovate-acuminate, sometimes slightly connate at the base, adnate to the foot of the column, $7 \mathrm{~mm}$ long, $3 \mathrm{~mm}$ wide. Petals oblong elliptic, obtuse to subacute, $2.5 \mathrm{~mm}$ long, $1 \mathrm{~mm}$ wide. Lip entire, ligulate, obtuse, very fleshy toward the apex, , geniculate in natural posistion, contracted at the base and articulate to the foot of the column, $2.5 \mathrm{~mm}$ long, $1 \mathrm{~mm}$ wide. Column subterete,3-lobed at apex, provided with a distinct foot at the base, about $1.8 \mathrm{~mm}$ long. Pollinia 4, in two cohalescent pairs. Anther cap operculate, triangular, 1-celled.

Distribution: Widespread but not common in lowlands in Central and South America, this species has been widely known as $B$. pachyrhachis, possibly an endemic of the West Indies.

Parque Nacional Manuel Antonio: A single plant of this species was found on fruit tree not far from the eastern border of PNMA. The plant was growing on a large branch partially covered by mosses in medium shade. It should be considered rare at PNMA.

Phenology: flowering occurs in December and January.

\section{CAMPYLOCENTRUM Benth.}

Epiphytic monopodial herbs with either distichous, leafy stems or leafless condensed stems. Leaves oblong or ligulate, coriaceous, sometimes absent. Inflorescence a short raceme, usually densely flowered, produced from the axils of the leaves or from the short stem at the center of the root cluster. Flowers often distichously arranged on the rhachis. Sepals subequal, free or partially connate; petals subequal to the sepals; lip sessile, 1-3 

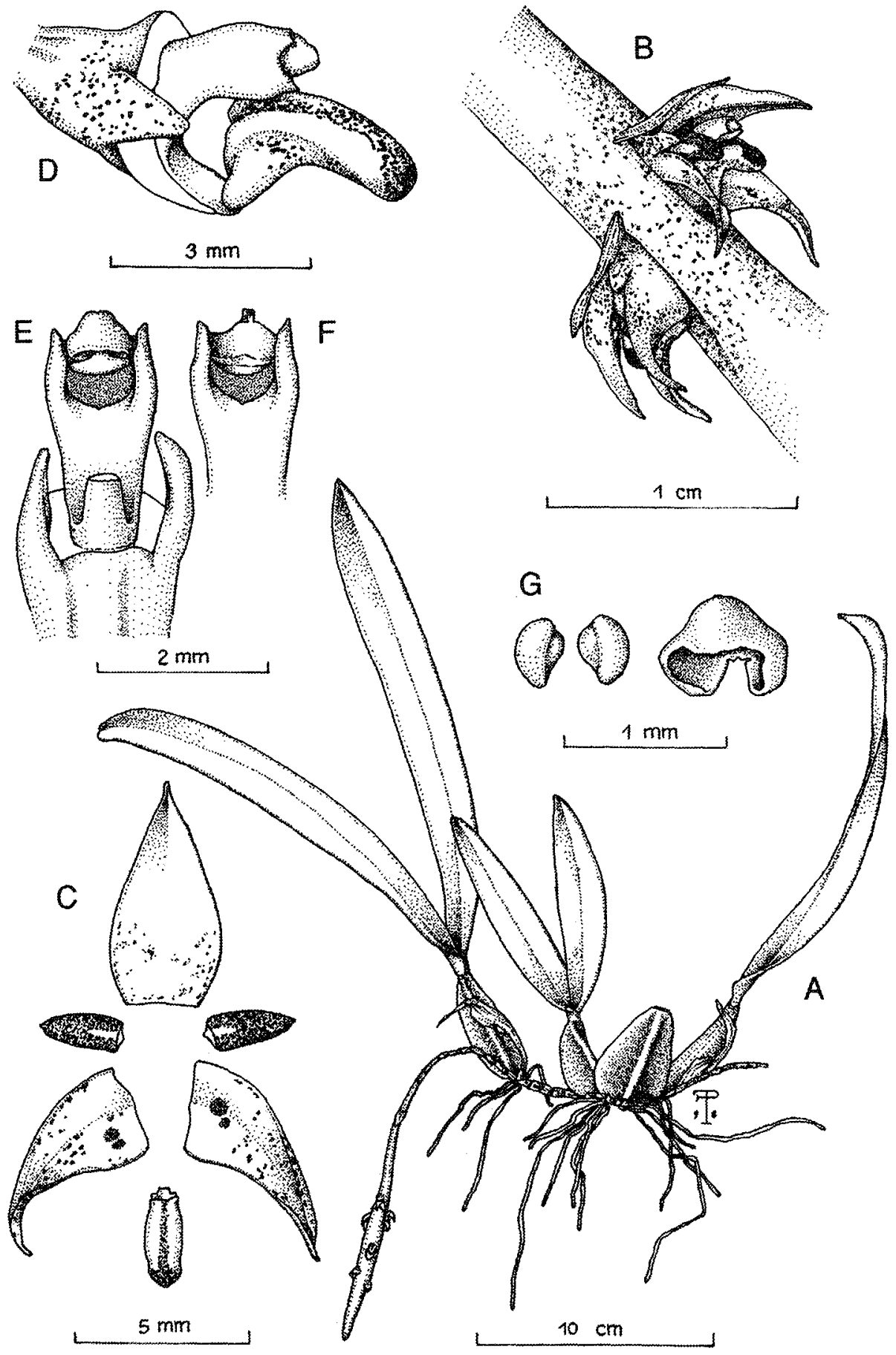

Fig. 8. Bulbophyllum oerstedii (A. Rich. \& Gal.) Hamer \& Garay. A - Habit. B - Flowers. C - Column and lip, lateral view. D - Dissected perianth. E - Column, ventral view. F - Apex of column, ventral view (anther removed). G. Pollinia and operculum. Illustration voucher: F. Pupulin 453. 
lobed, forming an elongate or saccate spur at the base. Column wingless, without a foot. Pollinia 2.

A neotropical genus of about 50 species.

\section{Campylocentrum micranthum (Lindl.)}

Rolfe, Orch. Rev. 11: 245. 1903. Angraecum micranthum Lindl., Bot. Reg. 21: t. 1772. 1836. Angraecum brevifolium Lindl., Bot. Reg. n.s. 3: sub t. 68. 1840. Angraecum lansbergii Rchb.f., Nederl. Kruidk. Arch. 4: 316. 1859. Aeranthus micranthus Rchb.f., Walp. Ann. 6: 901. 1864. Aeranthus lansbergii Rchb.f., Walp. Ann. 6: 901. 1864. Campylocentrum peniculus Schltr., Fedde Rep. Spec. Nov. Beih. 17: 91. 1922. (Fig. 9).

Plant epiphytic, monopodial, small, with terete stem to $20 \mathrm{~cm}$ long, leafy above. Roots fleshy, alternating to the leaves. Leaves eliptic to suborbicuar, distichous, coriaceous, obtuse, unequally 2-lobed at apex, articulate with the tubular sheath envolving the stem, pale green in color, to about $5 \mathrm{~cm}$ long, 2-2.5 $\mathrm{cm}$ wide. Inflorescence araceme produced from the stem below the leaves, usually shorter than the leaves, with the flowers arranged distichously on the rhachis. Floers small, white with the sur tinged by yellow, the segments not well spreading. Sepals subequal, lanceolate, acute, concave towards the base, to $5 \mathrm{~mm}$ long, $1.5 \mathrm{~mm}$ wide. Petals similar to the sepals, to $4.5 \mathrm{~mm}$ long, $1.3 \mathrm{~mm}$ wide. Lip 3/lobed, the lateral lobes broadly triangular, rounded at apex, clasping the midlobe triangular/ lanceolate, acute, concave, sparsely covered with short airs, to 5 $\mathrm{mm}$ long, $2 \mathrm{~mm}$ wide between the lateral lobes, extending at the base into a cylindric/clavate, down/turned spur about 4 mm long. Column short, about $1 \mathrm{~mm}$ long. Pollinia 2 on short ligualte stipes. Anther cap subquadrate/cucullate, $2 /$ celled.

Distribution: Widespread in lowlands throughout the neotropics, the species may be locally abundant.

Parque Nacional Manuel Antonio: Epiphytic on short trees in young secondary forest, where the plants are usually observed in exposed situations with their adventitious roots loosely anchored to the host twigs. Rare at PNMA.

Phenology: flowering mainly occurs in July-August.

\section{Campylocentrum panamense Ames,} Orchidaceae 7: 88. 1922. (Fig. 10).

Plant epiphytic, monopodial, pendent, with terete, leafy stem up to $50 \mathrm{~cm}$ long. Roots fleshy, alternating to the leaves. Leaves elliptic to linear-elliptic, distichous, emarginate, unequally 2-lobed at apex, articulate with the sheath envolvig the stem, dark green in color, to about $8.5 \mathrm{~cm}$ long, $2.5 \mathrm{~mm}$ wide. Inflorescence a raceme shorter than the leaves, produced along the stem, with the flowers arranged distichously on the rhachis, about $5 \mathrm{~cm}$ long. Flowers small, greenishwhite with the spur tinged by yellow, the segments not well spreading. Dorsal sepal linear-elliptic, obtuse, concave towards the base, $5 \mathrm{~mm}$ long, $1.5 \mathrm{~mm}$ wide. Lateral sepals linear-spathulate, wider near the base, acute, with a small apicule, concave, about $6 \mathrm{~mm}$ long, $1.3 \mathrm{~mm}$ wide. Petals similar to the dorsal sepal, to $4.5 \mathrm{~mm}$ long, $1.5 \mathrm{~mm}$ wide. Lip obscurely 3-lobed, the lateral lobes triangular, small, rounded at apex, clasping the column, the midlobe lanceolate, acute, concave, sparsely covered with hairs along the midrib, to $5 \mathrm{~mm}$ long, $2.2 \mathrm{~mm}$ wide between the lateral lobes, extending at the base into a cylindric, slightly curved spur, more or less continuous with the lip, about $5.5 \mathrm{~mm}$ long. Column short, $0.8 \mathrm{~mm}$ long. Pollinia 2 on short ligulate stipes. Anther cap subquadrate, 2-celled.

Distribution: Probably endemic in Costa Rica and Panama, but plants of this species may have been confused elsewhere with the widespread C. micranthum.

Parque Nacional Manuel Antonio: So far the species has not yet been collected within the Park area. A population was found in a riparian secondary forest on hills some $10 \mathrm{~km}$ West of PNMA. The plants grows on branches covered by mosses directly hanging over a little stream in shade. It should be considered rare at PNMA. 


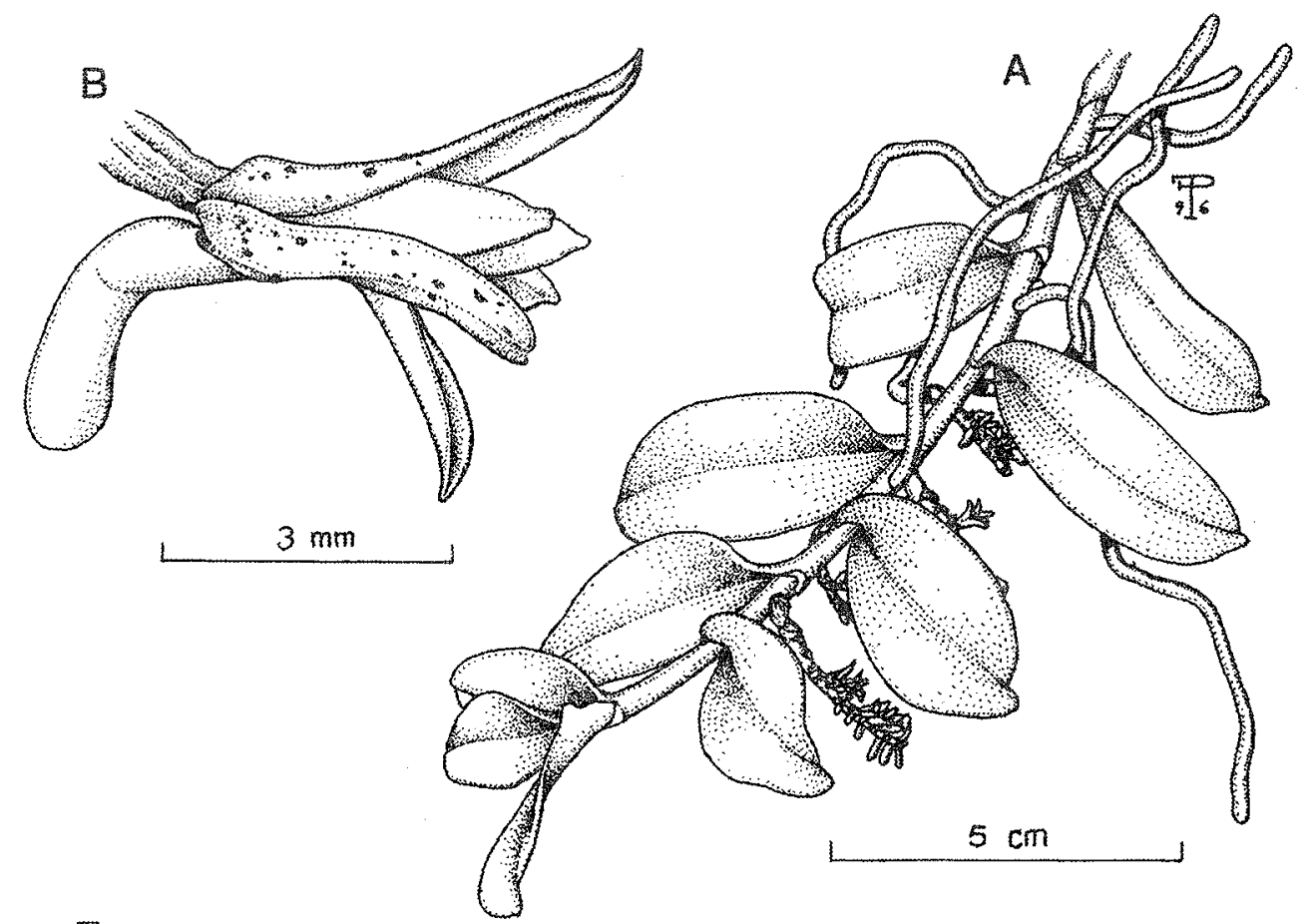

$\mathrm{E}$
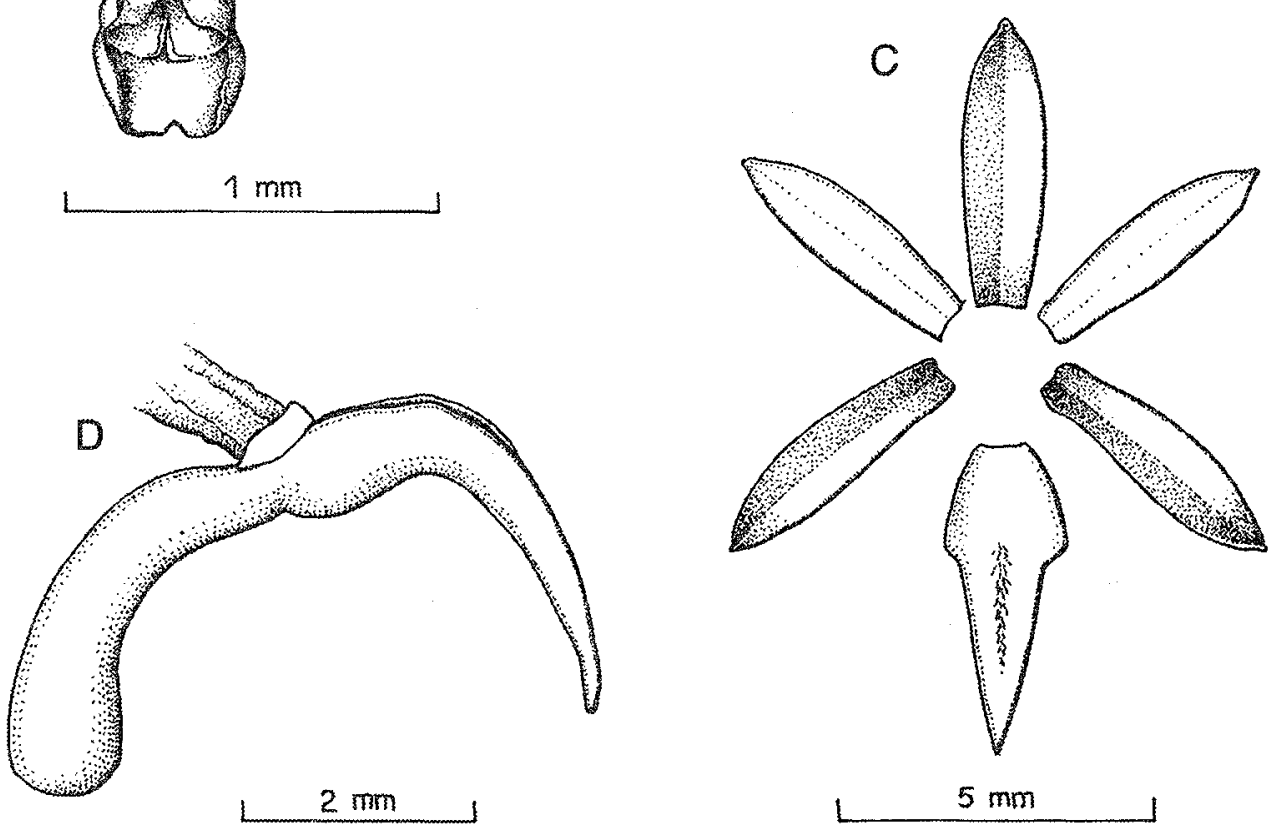

Fig. 9. Campylocentrum micranthum (Lindl.) Rolfe. A - Habit. B - Flower. C - Lip with spur, lateral view (sepals and petals removed). D - Dissected perianth. E - Operculum. Illustration voucher: F. Pupulin 332. 

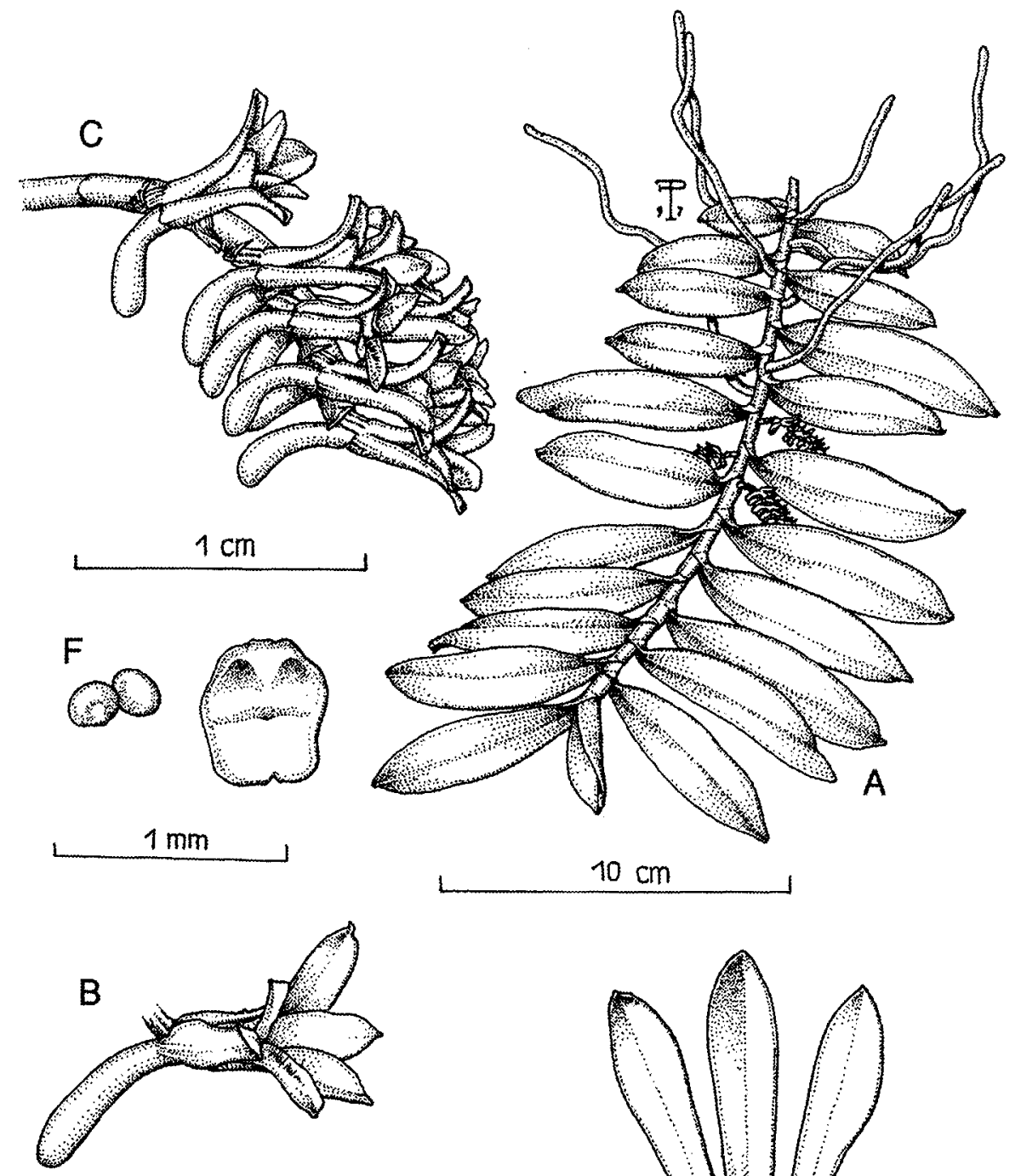

$1 \mathrm{~cm}$

D
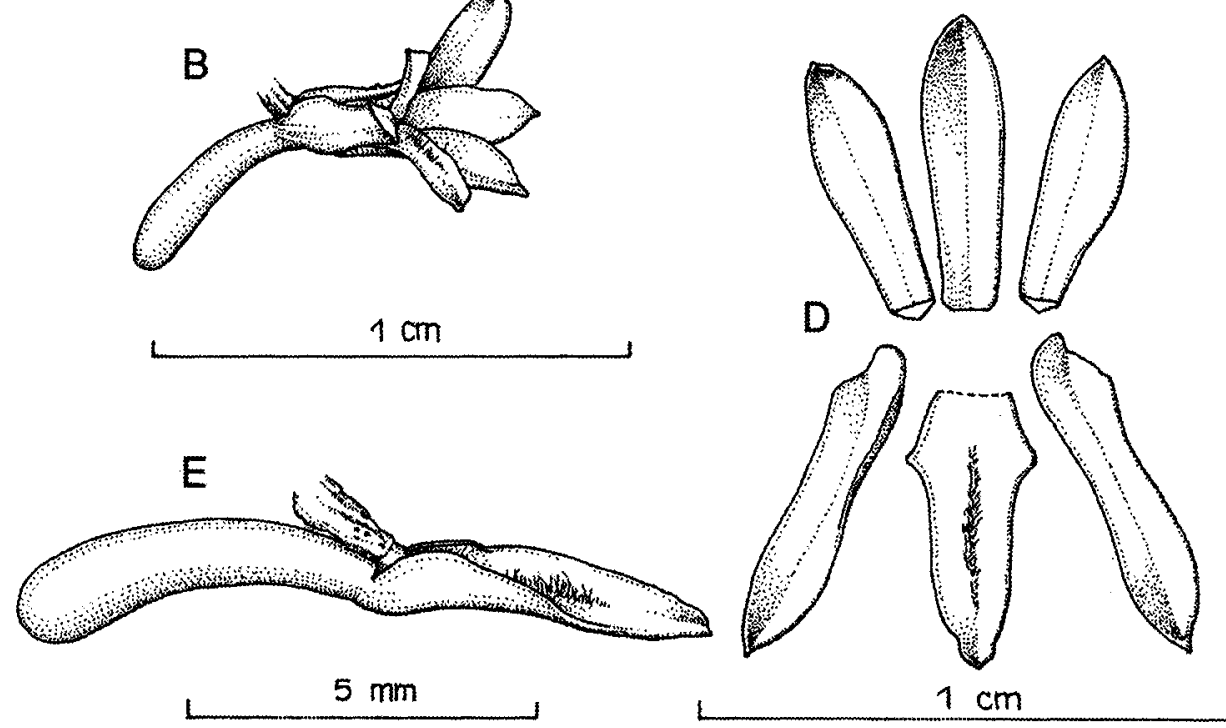

Fig. 10. Campylocentrum panamense Ames. A - Habit. B - Flower. C - Lip with spur, lateral view (sepals and petals removed). D - Dissected perianth. E - Operculum and pollinarium. Illustration voucher: F. Pupulin 305. 
Phenology: flowering occurs in September and October.

\section{CATASETUM L.C. Rich. ex Kunth}

Epiphytic or rarely terrestrial herbs with ovoid or fusiform, many-leaved pseudobulbs. Leaves usually large and plicate, deciduous. Inflorescence lateral, from near the base of the pseudobulb, a many-flowered raceme. Flowers usually large and conspicuous, unisexual, dimorphic, non-resupinate. Sepals and petals subequal, free, fleshy or membranaceous; lip thin or rigid, sessile, lateral compressed on deeply concave. Column erect, thickened, with or without a pair of antennae at the base in male flowers; shorter and thicker, without antennae in female flowers. Pollinia 4.

A genus of about 100 species restricted to the tropical regions of America.

1. Catasetum maculatum H.B.K., Syn. Pl. Aequinoct. 1: 331, 1822. Catasetum oerstedii Rchb.f., Bonplandia 3: 218, 1855. Catasetum rostratum Klinge, Acta Hort. Petropol. 17: 134, t. 2, 1898. Catasetum brenesii Schltr., Beitr. Ork. Zentralam. 2: 136 et 225, 1923. (Fig. 11).

Plant epiphytic, ascending, stout, with abbreviated rhizome, to $70 \mathrm{~cm}$ tall. Roots fleshy, glabrous, with many slender, erect, secondary rootlets, forming dense mats around the plant base. Psendobulbs subfusiformconical, to $30 \mathrm{~cm}$ long, $5-8 \mathrm{~cm}$ wide, covered by 5-6 scarious, imbricating leaf-sheaths. Leaves 6 to 8, distichous, elliptic-lanceolate to oblong-elliptic, acute to acuminate, plicate, strongly nerved, up to $45 \mathrm{~cm}$ long, $8-12 \mathrm{~cm}$ wide, the blades deciduous, the persistent bracts enveloping the pseudobulbs armed at apex with sharped spines. Inflorescence lateral, basal, erect to arching, racemose, 3-to 14-flowered, up to $40 \mathrm{~cm}$ long. Ovaries pedicellate, stout, arcuate, to $3 \mathrm{~cm}$ long. Flowers relatively large, non-resupinate, unisexual, dimorphic, staminate and pistillate flowers produced on separate inflorescences.
Staminate flowers (male) yellowish-green, suffused and spotted by purple. Dorsal sepal membranaceous, oblong-elliptic to lanceolate, acuminte, concave, to $4.2 \mathrm{~cm}$ long, $1.6 \mathrm{~cm}$ wide. Lateral sepals membranaceous, obliquely lanceolate, acuminate, to $4.4 \mathrm{~cm}$ long, $1.9 \mathrm{~cm}$ wide. Petals membranaceous, elliptic-lanceolate, acuminate, mucronate at apex, $4 \mathrm{~cm}$ long, $1.8 \mathrm{~cm}$ wide. Lip fleshy, rigid, saccate, obconic, $3 \mathrm{~cm}$ long, $2.5 \mathrm{~cm}$ wide, margins of the basal portion of the orifice ciliate, apex of the orifice slightly emarginate. Column stout, rostrate, concave, $3.2 \mathrm{~cm}$ long, $1.2 \mathrm{~cm}$ wide, with 2 slender, elongate antennae projecting downward, one unciform, the other undulate, extending into the calceolate lip. Pollinia 2, obovate, sulcate, on a obtriangular deflexed stipe; viscidium peltate. Anther cap cucullate-rostrate, 2celled. Pistillate flowers (female) yellowish green, spotted by purple at the base of petals. Sepals and petals reflexed, fleshy. Sepals subequal, broadly ligular, apiculate at apex, to $2.8 \mathrm{~cm}$ long, $2 \mathrm{~cm}$ wide. Petals ellipticlanceolate, acute, to $2.5 \mathrm{~cm}$ long, $1.9 \mathrm{~cm}$ wide. Lip fleshy, rigid, saccate, $3.1 \mathrm{~cm}$ long, about 2 $\mathrm{cm}$ wide, margins of the orifice smooth. Column fleshy, very stout, to $1.4 \mathrm{~cm}$ long, 1.2 $\mathrm{cm}$ wide, with a short apicule on upper apex.

Distribution: From Mexico to Colombia. Rather common at lower elevations in Central America.

Parque Nacional Manuel Antonio: Epiphytic on Tabebuia rosea (roble de sabana), Hymenaea courbaril (guapinol), Cocos nucifera and Terminalia catappa (almendro de playa) trees just to the line of seashore, generally exposed to full sunlight. Pollinated by the bee Eulaema cingulata (Allen 1952). Common at PNMA.

Phenology: flowering mainly occurs in July-August.

\section{CAULARTHRON Rafin.}

Epiphytic herbs with fusiform, usually hollow pseudobulbs inhabited by ants, few-leaved 

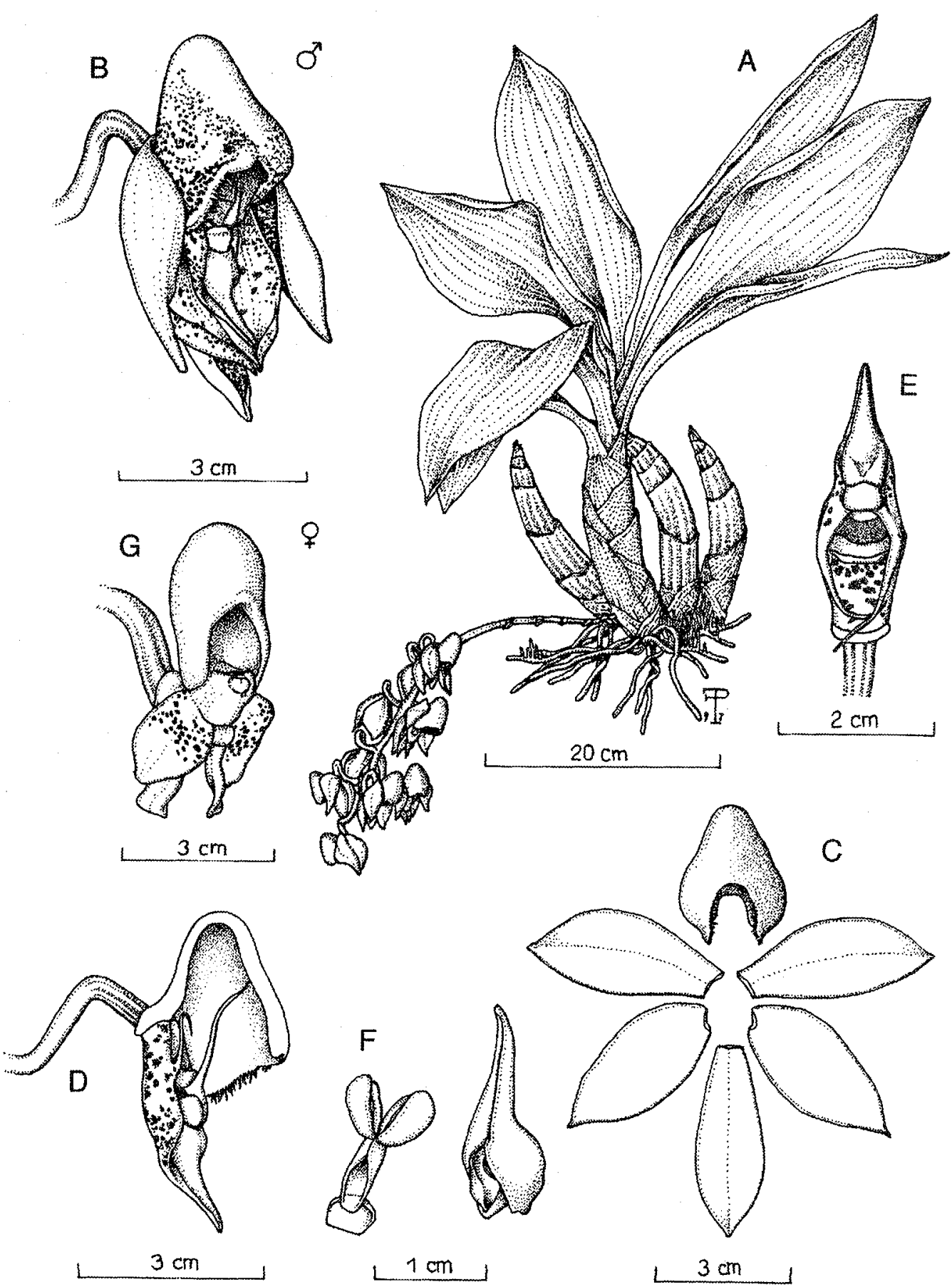

Fig. 11. Catasetum maculatum Kunth. A - Habit. B - Male flower. C - Male column and lip, lateral view (the lip longitudinally sectioned, sepals and petals removed). D - Dissected male flower. E - Male column, ventral view. F Pollinarium and operculum. G - Female flower. Illustration voucher: A-F, F. Pupulin 323; G, F. Pupulin 327. 
at apex. Leaves conduplicate, coriaceous. Inflorescence terminal from the apex of the pseudobulb, a many-flowered raceme. Flowers small or large and conspicuous. Sepals and petals similar, free, spreading; lip 3-lobed, free from the column, with two horn-like, hollow projections near the base. Column short, flat, without a foot, provided with lateral wings. Pollinia 4.

A neotropical genus of about 4 species.

\section{Caulerheron bilamellatum (Rchb.f.)} R.E.Schuleses, Bot. Mus. leaf. 18: 92. 1958. Epidendrum bilamellatum Rchb.f., Walp. Ann. Bot. Syst. 6: 345. 1862. Epidendrum bigibberosum Rchb.f., Walp. Ann. Bot. Syst. 6: 346. 1862. Diacrium bigibberosum Hernsl., Godm. \& Salvin Biol. Centr-Amer. Bot. 3: 222. 1883. Diacrium bilamellatum Hemsl., Godm. \& Salvin Biol. Centr.-Amer. Bot. 3: 222. 1883. Diacrium indivisum Broadway, Bull. Misc. Inform. Trinidad 2: 79. 1895. Diacrium venezuelanum Schltr., Repert. Spec. Nov. Regni Veg. Beih. 6: 41. 1919. Diacrium bilamellatum var. reichenbachianum Schltr., Repert. Spec. Nov. Regni Veg. Beih. 17: 47. 1922, in textu. Diacritum bivalvatulum Schltr., Repert. Spec. Nov. Regni Veg. Beih. 19: 123. 1923. (Fig. 12).

Plant epiphytic, ascending, stout, with short rhizome, to $50 \mathrm{~cm}$ tall. Roots fleshy, glabrous. Pseudobulbs cylindric to fusiform, swollen, of several nodes, to $30 \mathrm{~cm}$ long, $2.5-4$ $\mathrm{cm}$ wide, covered by many imbricating, pale green sheaths, turning withish grey with age, 2-4 leaved at apex. Leaves elliptic to ligulateelliptic, obtuse, fleshy, up to $18 \mathrm{~cm}$ long, 0.8 $2.5 \mathrm{~cm}$ wide. Inflorescence terminal from the apex of the pseudobulb, a raceme erect, several-flowered, the flowers opening successively at the end of an elongate peduncle up to $40 \mathrm{~cm}$ long. Ovaries pedicellate, to $3 \mathrm{~cm}$ long. Flowers white, the apex of sepals suffused by rose-brown, often cleistogamous. Sepals subequal, elliptic to elliptic-obovate, acute, dorsally carinate, $1.5 \mathrm{~cm}$ long, $0.9 \mathrm{~cm}$ wide. Petals broadly obovate, with a short claw, subacute, $1.5 \mathrm{~cm}$ long, $1 \mathrm{~cm}$ wide. Lip $3-$ lobed, ovate-lanceolate, the obscure lateral lobes widely triangular, the midlobe acute to slightly apiculate, the entire lip $1.6 \mathrm{~cm}$ long, $0.7 \mathrm{~cm}$ wide, provided at the base with two small rounded lobules; disc with two large, lamellate, hollow, horn-like projections near the middle. Column stout, concave, $9 \mathrm{~mm}$ long, with 2 wide, rounded wings at the middle. Pollinia 4, laterally compressed, each pair provided with a granular, viscid, claudicle. Anther cap cucullate.

Distribution: From Guatemala to Venezuela, Trinidad, and Ecuador. Rather common at lower elevations and in dry forests in Central and northern South America.

Parque Nacional Manuel Antonio: Epiphytic on Tabebuia rosea (roble de sabana) and Terminalia catappa (almendro de playa) trees, mainly close to the sea, in medium shaded situations or exposed to full sunlight. Sometimes the flowers are self-pollinating before bud opening. Common at PNMA.

Phenology: flowering mainly occurs in March-April.

\section{DICHAEA Lindl.}

Epiphytic monopodial herbs, lacking pseudobuibs, pendent or rarely erect, with foliaceous stem. Leaves conduplicate, articulate or not, membranaceous or coriaceous. Inflorescence lateral from the axils of the leaves, 1-flowered on a short peduncle. Flowers small or medium sized. Sepals and petals subequal, free or the laterals sepals slightly connate, spreading; lip clawed, 3lobed or rarely entire. Column short, erect, with a short foot, provided with a infastigmatic ligule. Pollinia 4, waxy.

A neotropical genus of about 45 species, often restricted to the trunks and lower branches of the host trees.

1. Dichaea panamensis Cindll, Gen. et Spec. Orch. P1. 209. 1833. Epithecia panamensis Schltr., Orchis 9: 25. 1815. Dichaeopsis panamensis (Lindl.) Schltr., Beih Bot. Centralbl. 36(2): 519. 1918. (Fig. 13). 

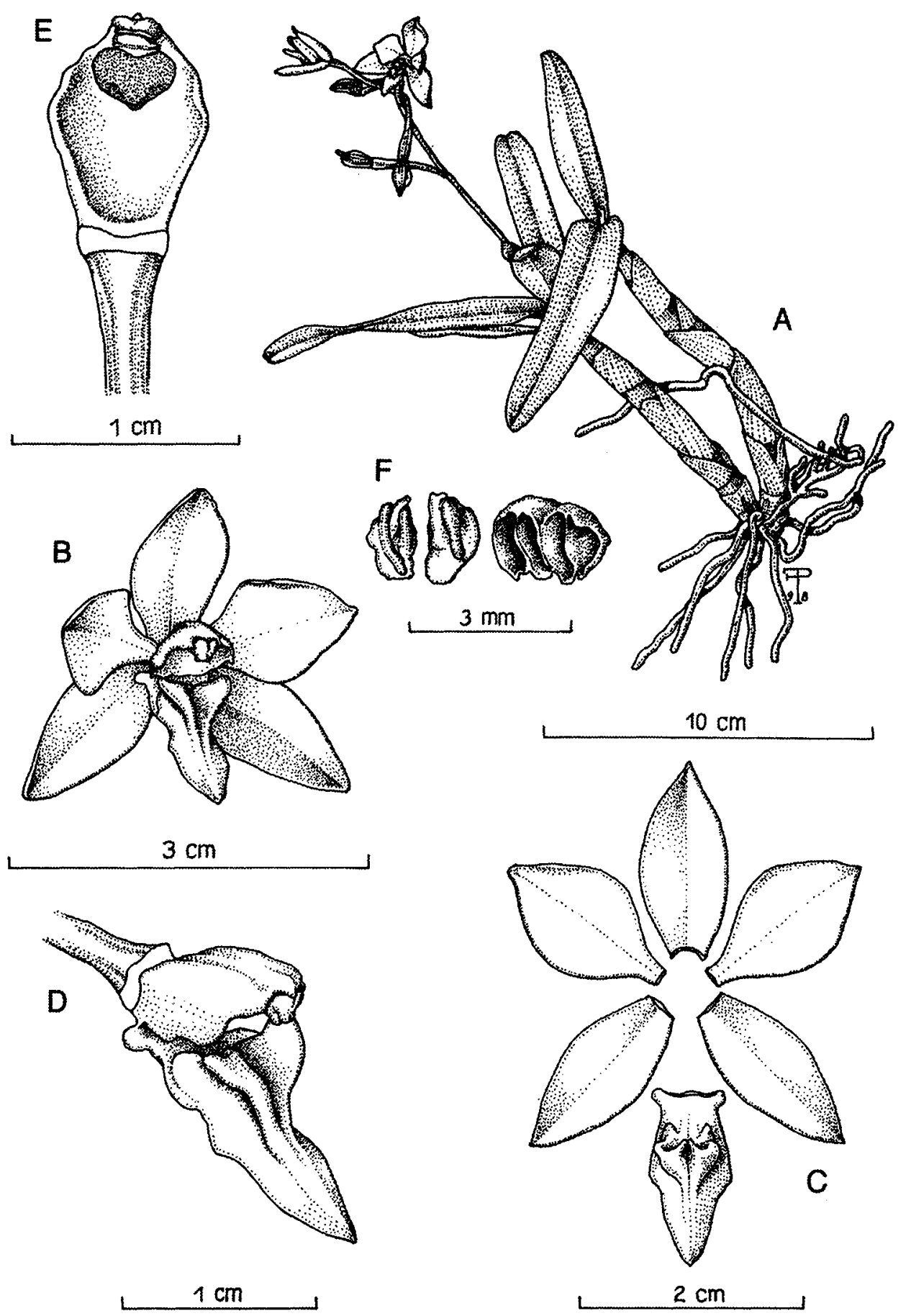

Fig. 12. Caulathron bilamellatum (Rchb.f.) R.E. Schult. A - Habit. B - Floer. C - Column and lip, lateral view (speals and petals removed). D - Dissected perianth. E - Column, ventral view. F. Pollinaria and operculum. Illustration voucher: F. Pupulin 355. 

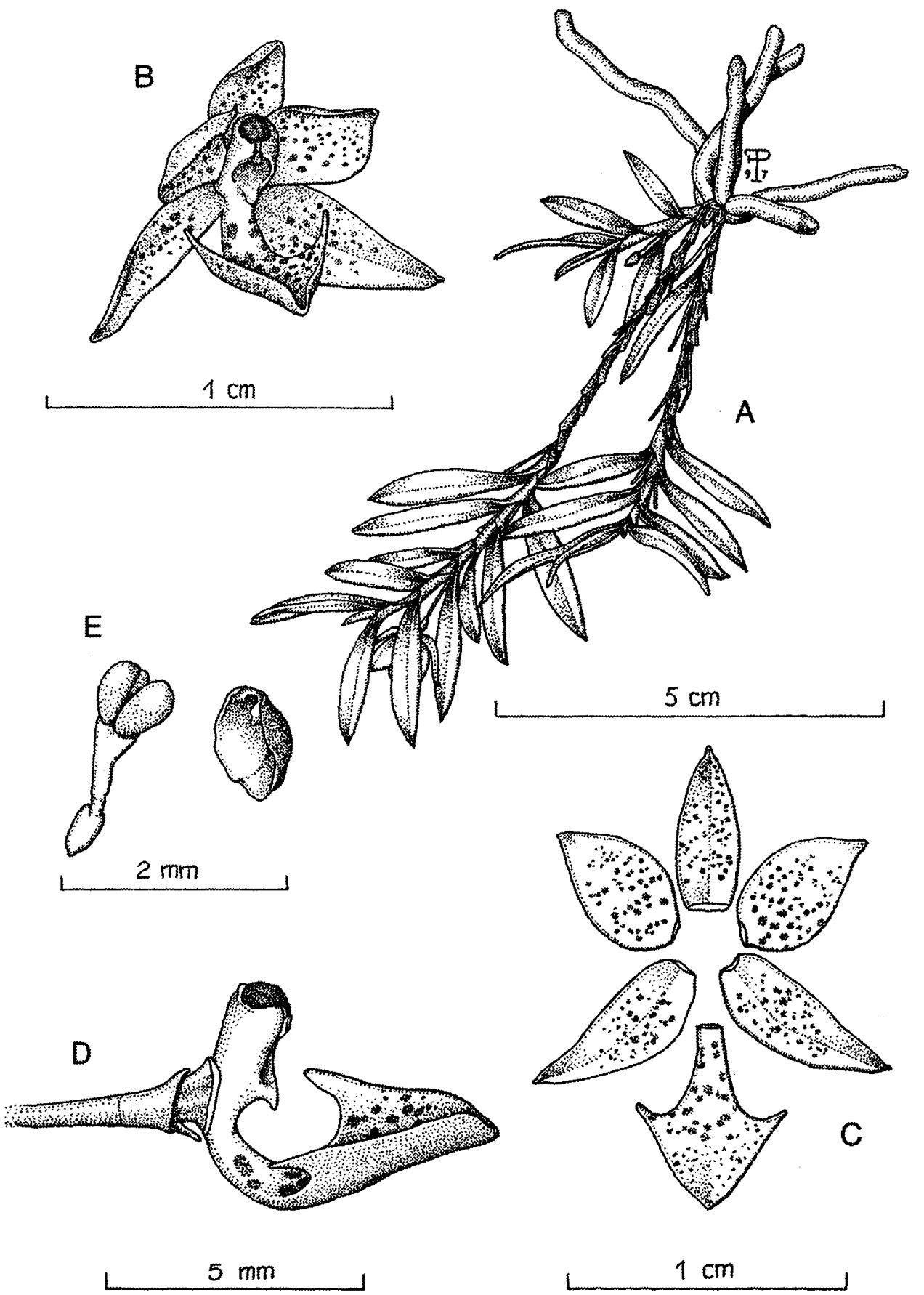
Plant epiphytic, pendent, with monopodial, foliaceous stem, up to about 15 $\mathrm{cm}$ tall. Roots fleshy, glabrous, wider than the stem, about $2 \mathrm{~mm}$ in diameter. Leaves arranged distichously on the stems, narrowly linear-elliptic, acute and apiculate, subcoriaceous, $1.2-2 \mathrm{~cm}$ long, $0.3-0.4 \mathrm{~cm}$ wide, the blade articulated to sheath envolving the stem and ultimately deciduous. Inflorescences lateral from axils of the leaves, 1-flowered, on a short peduncle $1.5 \mathrm{~cm}$ long. Ovaries pedicellate, glabrous, about $2 \mathrm{~mm}$ long. Flowers greenish white spotted with violet. Dorsal sepal ovate-elliptic, acute, dorsally carinate, $6 \mathrm{~mm}$ long, $2.5 \mathrm{~mm}$ wide. Lateral sepals ovate-lanceolate, slightly falcate, acute, apiculate, $7.5 \mathrm{~mm}$ long, $3 \mathrm{~mm}$ wide. Petals obliquely ovate, acute, $6 \mathrm{~mm}$ long, $4 \mathrm{~mm}$ wide. Lip 3-lobed, anchoriform to sagittate, with a fleshy claw, the lateral lobes narrow, retrorse, acute, the midlobe broadly triangular, shortly acute, adaxially carinate towards the apex, the entire lip $7 \mathrm{~mm}$ long, 6 $\mathrm{mm}$ wide between the lateral lobes. Column erect, with a short foot, provided at the base of the stigmatic cavity with a glabrous ligule, 2.5 mm long. Pollinia 4, laterally compressed, in two pairs superposed, on a triangular elongate stipe. Anther cap hemiglobose, 2-celled.

Distribution: A very common epiphyte in Central America. It is usually found in shade on trunks and branches of understory trees at low elevations from Mexico to Panama.

Parque Nacional Manuel Antonio: The species has not yet been collected within the Park. Plants were found at the base of a large Ceiba sp., in primary forest remnants, on hills some $10 \mathrm{~km}$ West of PNMA. So far, it should be considered rare at PNMA.

Phenology: flowering occurs throughout the year.

\section{DIMERANDRA Schltr}

Herbs epiphytic, cespitose, with thickened, foliaceous stem. Leaves conduplicate, linear to narrowly elliptic, subcoriaceous, scattered along the upper part of the stems. Inflorescence terminal, a very short, few- successively flowered raceme. Flowers of medium size, showy, rose-purple with white center. Sepals and petals subsimilar, spreading, the petals wider; lip simple with a short claw, provided with a callus formed by several obscure carines. Column short, apically provided with two wings. Pollinia 4 , waxy.

A genus of about 8 species, often selfpollinating, widely distributed in drier forest throughout tropical America.

1. Dimerandra emarginata (G.F.W. Meyer) Hoehne, Bol. Agric. (São Paulo) 34: 618. 1934. Oncidium emarginatum G.F.W. Meyer, Prim. Fl. Essequeb. 259. 1818. Epidendrum stenopetalum J.D. Hook., Bot. Mag. 62: t. 3410. 1835. Epidendrum stenopetalum var. tenuicaule Rchb.f., Otia Bot. hamb. 1: 12. 1878. Dimerandra stenopetala (J.D. Hook.) Schltr., Repert. Spec. Nov. Regni Veg. Beih. 17: 44. 1922. (Fig. 14).

Plant epiphytic, cespitose, with fleshy, foliaceous stem, up to about $60 \mathrm{~cm}$ tall. Pseudobulbs cylindric to fusiform from a narrow stalk, of several nodes, bearing leaves in the upper portion. Roots fleshy, glabrous. Leaves arranged distichously on the stems, narrowly linear-elliptic, subcoriaceous, unequally bilobed at apex, $4-9 \mathrm{~cm}$ long, $0.7-$ $1.1 \mathrm{~cm}$ wide, produced at the nodes of the pseudobulb. Inflorescences terminal, a short raceme bearing 1 - to few flowers produced successively about $1 \mathrm{~cm}$ long. Flowers very flat, often self-pollinating, rose purple with a white blotch at the base of the lip. Sepals subsimilar, elliptic-lanceolate, acute to acuminate, the lateral sepals somewhat oblique, $15 \mathrm{~mm}$ long, $5 \mathrm{~mm}$ wide. Petals broad-obovate to subrhombic, acute, $17 \mathrm{~mm}$ long, $10 \mathrm{~mm}$ wide. Lip flabellate, with a fleshy claw partially adnate to the column, the lamina broadly obovate to suborbicular, truncate, slightly apiculate, the disc with a callus composed by obscure lines, the entire lip 16 $\mathrm{mm}$ long, $15 \mathrm{~mm}$ wide. Column short, without 


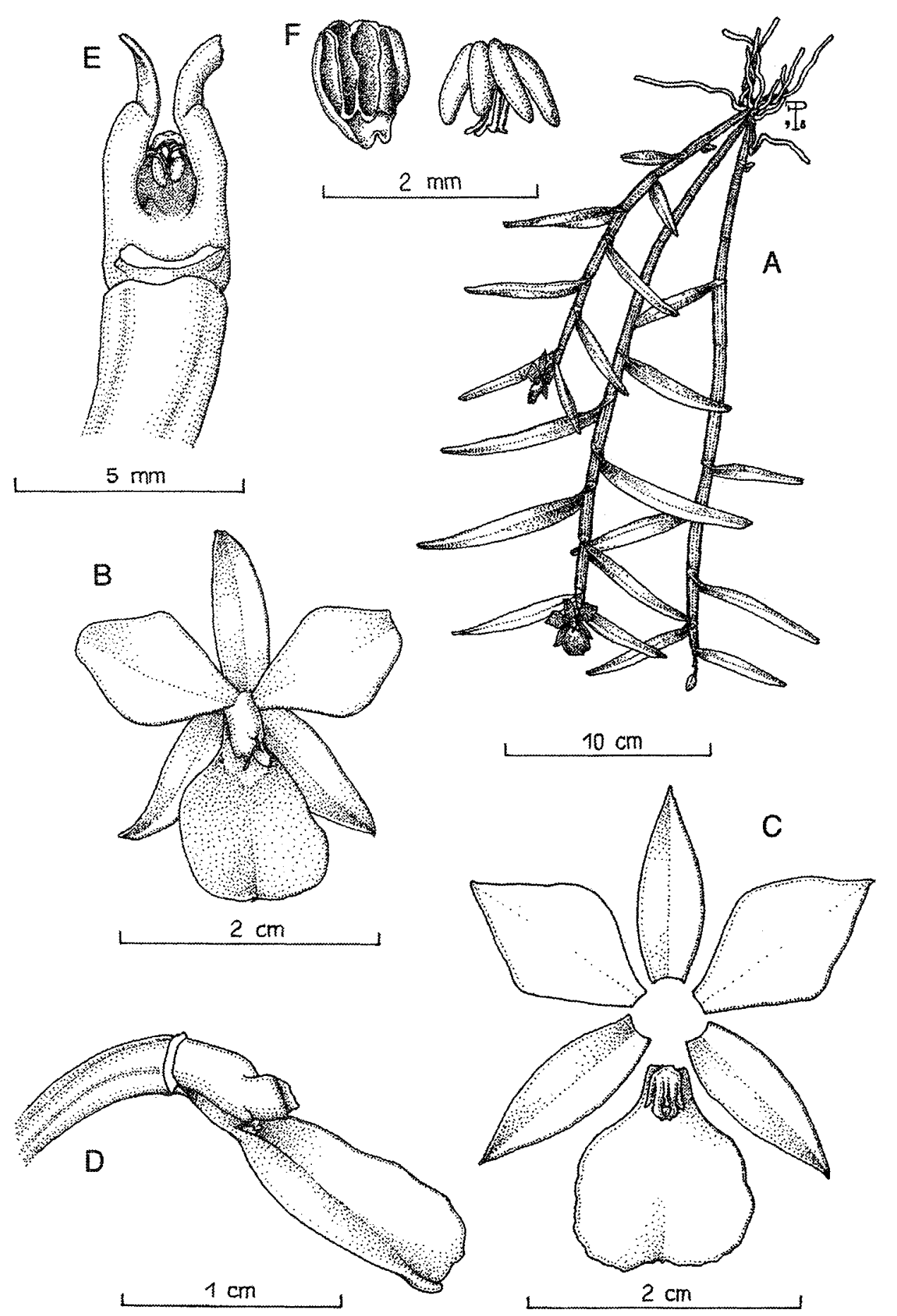

Fig. 14. Dimerandra emarginata (G.F.W. Meyer) Hohene. A - Habit. B - Flower. C - Column and lip, lateral view (sepals and petals removed). D - Dissected perianth. E - Pollinaria and operculum. Illustration voucher: F. Pupulin 325. 
a foot, provided at the apex with two, large, subquadrate, deflexed wings, about $5 \mathrm{~mm}$ long. Pollinia 4, laterally compressed, in two pairs on short, bilobed caudicles. Anther cap hemiglobose, 4-celled.

Distribution: A common epiphyte in tropical America. It is usually found at low elevations from Mexico to South America and the West Indies.

Parque Nacional Manuel Antonio: The species may be observed growing epiphytically in any kind of vegetation at the Park, the plants often forming big clumps of many stems, usually pendent in mature specimen. Sometimes the flowers are selfpollinating soon after bud opening. Very common at PNMA.

Phenology: flowering occurs from September through December.

\section{ENCYCLIA Hook.}

Epiphytic herbs with ovoid or elongated, heteroblastic pseudobulbs, 1- to 3-foliate at apex, the base envolved in papyraceous sheaths. Leaves conduplicate, oblong to linear, subcoriaceous to leathery. Inflorescence terminal, sometimes produced from a small to large spathaceous bract, a few- to manysuccessively flowered raceme or panicle. Flowers from small to large and showy. Sepals subequal, free, spreading; the petals usually similar to sepals or slightly narrower or broader; lip free from the column or adnate only at the base, simple or 3-lobed, provided with various kinds of calli. Column stout or slender, footless, often provided with apical wings. Pollinia 4, waxy.

A neotropical genus of about 150 species, usually well represented in areas with well defined seasonality.

1. Encyclia abbreviata (Schltr.) Dressler, Brittonia 13: 264. 1961. Epidendrum abbreviatum Schltr., Repert. Spec. Nov. Regni Veg. 3: 107. 1906. Epidendrum prorepens Ames, Sched. Orch. 2: 33. 1923. (Fig. 15).
Plant epiphytic, with elongate rhizome and well spaced pseudobulbs, up to about 20 $\mathrm{cm}$ tall. Pseudobulbs stalked, fusiform, slightly flattened, $4-5 \mathrm{~cm}$ long, to $0.9 \mathrm{~cm}$ wide, 2- to 3-leaved at apex. Roots filiform, glabrous. Leaves narrowly linear-elliptic, soft, minutely retuse, $4-15 \mathrm{~cm}$ long, $0.4-1 \mathrm{~cm}$ wide. Inflorescences terminal, a short raceme bearing 2-4 flowers, produced from a inconspicuous spathe, about $1.5 \mathrm{~cm}$ long. Flowers small, creamy white striped with violet on the lip. Sepals subsimilar, lanceolate, acute, the lateral sepals oblique, 13 $\mathrm{mm}$ long, $2.5 \mathrm{~mm}$ wide. Petals oblanceolate, acute, $12 \mathrm{~mm}$ long, $2 \mathrm{~mm}$ wide. Lip with a short claw, adnate to basal half of the column, flabellate, the lamina ovate, rounded to cordate basally, acute, the disc with a subquadrate thickening, $11 \mathrm{~mm}$ long, $7 \mathrm{~mm}$ wide. Column subterete, flattened, widened at the middle, 3-toothed at apex, the mid-tooth shorter than the lateral ones, about $5 \mathrm{~mm}$ long. Pollinia 4, laterally compressed, in two pairs on bilobed caudicles. Anther cap hemiglobose, 4-celled.

Distribution: From Mexico to Central America, usually in evergreen forest just to 1,000 meters elevations.

Parque Nacional Manuel Antonio: The species has been found growing epiphytically in secondary forest in shaded conditions. Rare at PNMA.

Phenology: flowering mostly occurs in May-June.

\section{EPIDENDRUM L.}

Small to large, cespitose or repent, erect to pendent, epiphytic or rarely terrestrial herbs to subshrubs, occasionaly provided with pseudobulbs. Leaves conduplicate, subcoriaceous to fleshy. Inflorescence terminal, rarely lateral, a 1- to many-flowered raceme, panicle or umbel. Flowers small to large and showy. Sepals and petals subsimilar, free, usually spreading; the lip simple or lobed, adnate to the column, usually with fleshy calli 

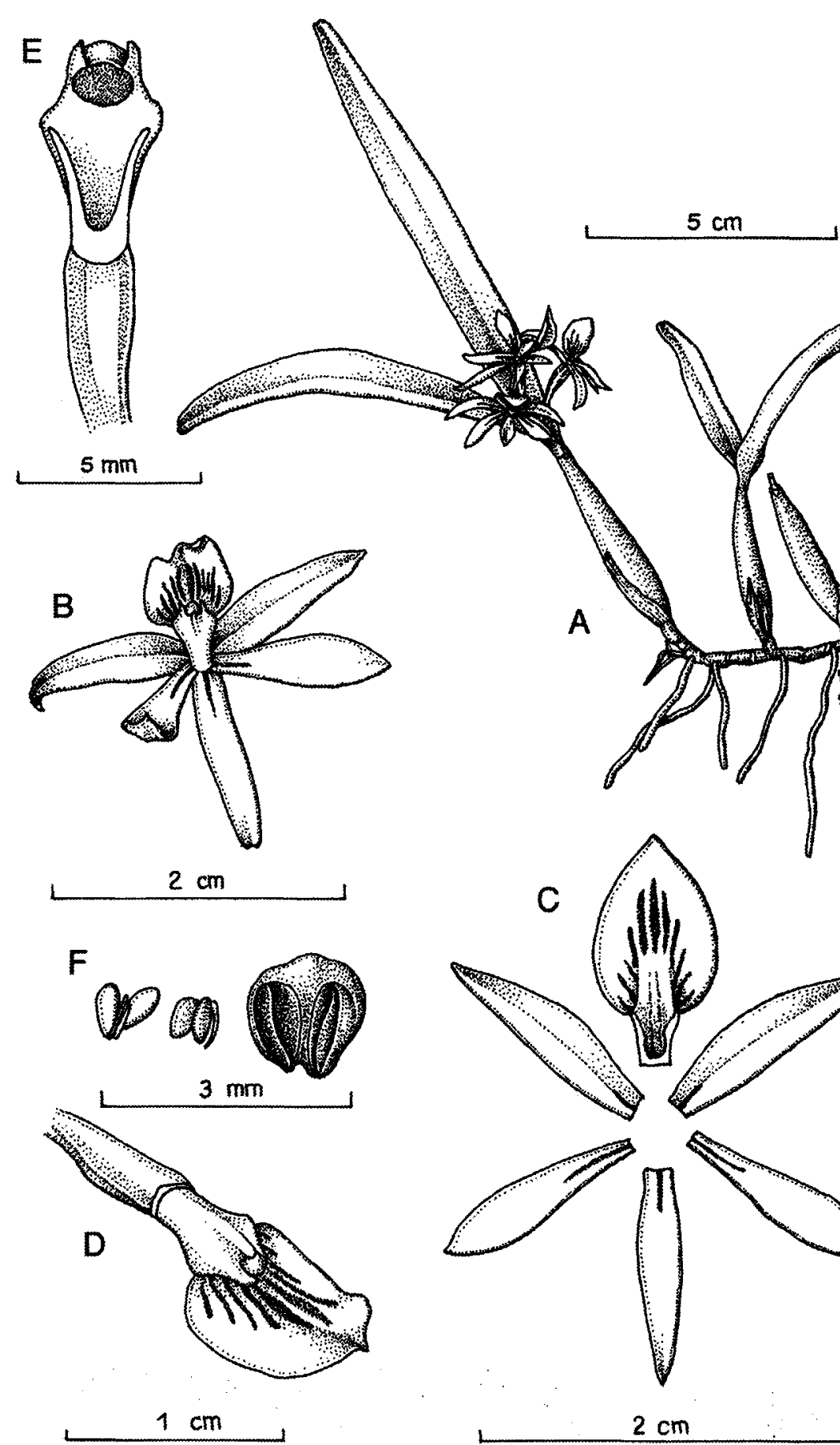
at the base. Column fused with the lip just to the apex, often provided with a hooded clinandrium. Pollinia 4, waxy.

A genus of about 600 species, widespread in American tropics and subtropics from southern USA to Argentina.

1. Epidendrum amparoanum Schltr., Repert. Spec. Nov. Regni Veg. Beih. 19: 34. 1923. (Fig. 16).

Plant epiphytic, cespitose, without pseudobulbs, with short rhizome and foliaceous stems up to $35 \mathrm{~cm}$ tall. Stems elongate, flattened, $35 \mathrm{~cm}$ long, to $1.4 \mathrm{~cm}$ in diameter, completely enfolded by the tubular, leaf-bearing sheaths, 5- to 9-leaved. Roots fleshy, flexuous, glabrous. Leaves ellipticoblong, coriaceous, retuse , $3.5-8 \mathrm{~cm}$ long, 1-3 $\mathrm{cm}$ wide. Inflorescence terminal, a short subumbellate, subsessile raceme bearing 3-5 flowers, produced from the axil of the upper leaf. Flowers medium sized, pale green. Sepals subsimilar, lanceolate-elliptic, acute, the lateral sepals somewhat falcate, $32 \mathrm{~mm}$ long, $10 \mathrm{~mm}$ wide. Petals linear elliptic, acute, $28 \mathrm{~mm}$ long, $5 \mathrm{~mm}$ wide. Lip with a short claw adnate to the column, the lamina 3-lobed, widely reniform, deeply cordate at the base, somewhat 3-lobed at apex, apiculate, $28 \mathrm{~mm}$ long, $35 \mathrm{~mm}$ wide; the disc with two thickened, rounded, slightly diverging calli. Column clavate, with a terminal tooth, margins of the clinandrium erose, $12 \mathrm{~mm}$ long. Pollinia 4, laterally compressed, on a short caudicle. Anther cap hemiglobose, 4-celled.

Distribution: Costa Rica and Panama, from sea level to about 1,500 meters.

Parque Nacional Manuel Antonio: The species is widespread within the park, where it is obiquitarious in all vegetation units just to the seashore. The flowers emit a plastic-like smell, that is stronger in the last hours of the day. Very common at PNMA.

Phenology: flowering mostly occurs in July-August.

2. Epidendrum congestum Rolfe, Kew Bull. 1913: 29. 1913. Epidendrum serruliferum Schltr., Repert. Spec. Nov. Regni Veg. Beih. 19: 44. 1923. (Fig. 17).

Plant epiphytic, cespitose, without pseudobulbs, with abbreviate, foliaceous stems, up to $5 \mathrm{~cm}$ tall. Stems flattened, to $5 \mathrm{~cm}$ long, $0.8 \mathrm{~cm}$ in diameter, completely concealed by closely appressed leaf sheaths, 5 to 11-leaved. Roots filiform, flexuous, glabrous. Leaves distichous, elliptic-ovate, fleshy, retuse, dorsally apiculate, $1-2.3 \mathrm{~cm}$ long, $0.6-0.9 \mathrm{~cm}$ wide, not articulated with the sheaths, the margins somewhat revolute. Inflorescence terminal from the upper leaf, sessile, 1-2 flowered. Flowers small, pale green with purplish suffusion, the lip emerald green. Sepals subsimilar, elliptic-lanceolate, acute, the margins somewhat denticulate, dorsally carinate, the lateral sepals falcate, concave, with a serrulate carine, $10-12 \mathrm{~mm}$ long, $4 \mathrm{~mm}$ wide. Petals oblique, narrowly lanceolate, subacute, the apical margins denticulate, $9 \mathrm{~mm}$ long, $2.8 \mathrm{~mm}$ wide. Lip with a ligulate claw adnate to the column, the lamina ovate, somewhat cordate at the base, acute, mucronate, $9 \mathrm{~mm}$ long, $5.5 \mathrm{~mm}$ wide. Column short, stout, with a 3-toothed clinandrium, the margins erose, $5 \mathrm{~mm}$ long. Pollinia 4, laterally compressed, on a short caudicle. Anther cap hemiglobose, 4-celled.

Distribution: Endemic to Costa Rica.

Parque Nacional Manuel Antonio: Widespread within the park, it is usually found in lighted spots just to the seashore, closely appressed to the host tree but sometimes loosely hanging from the branchlets. Plants exposed to full sunlight present a strong purple pygmentation on the leaves and the flowers. The species is common at PNMA.

Phenology: flowering mostly occurs in April-May.

3. Epidendrum isomerum Schltr., Repert. Spec. Nov. Regni Veg. 2: 132. 1906. Epidendrum guayasense Schltr., Repert. Spec. Nov. Regni Veg. 8: 73. 1921.

Plant epiphytic, pendent, without pseudobulbs, up to $130 \mathrm{~cm}$ tall. Stems foliaceous, simple or commonly branched, 

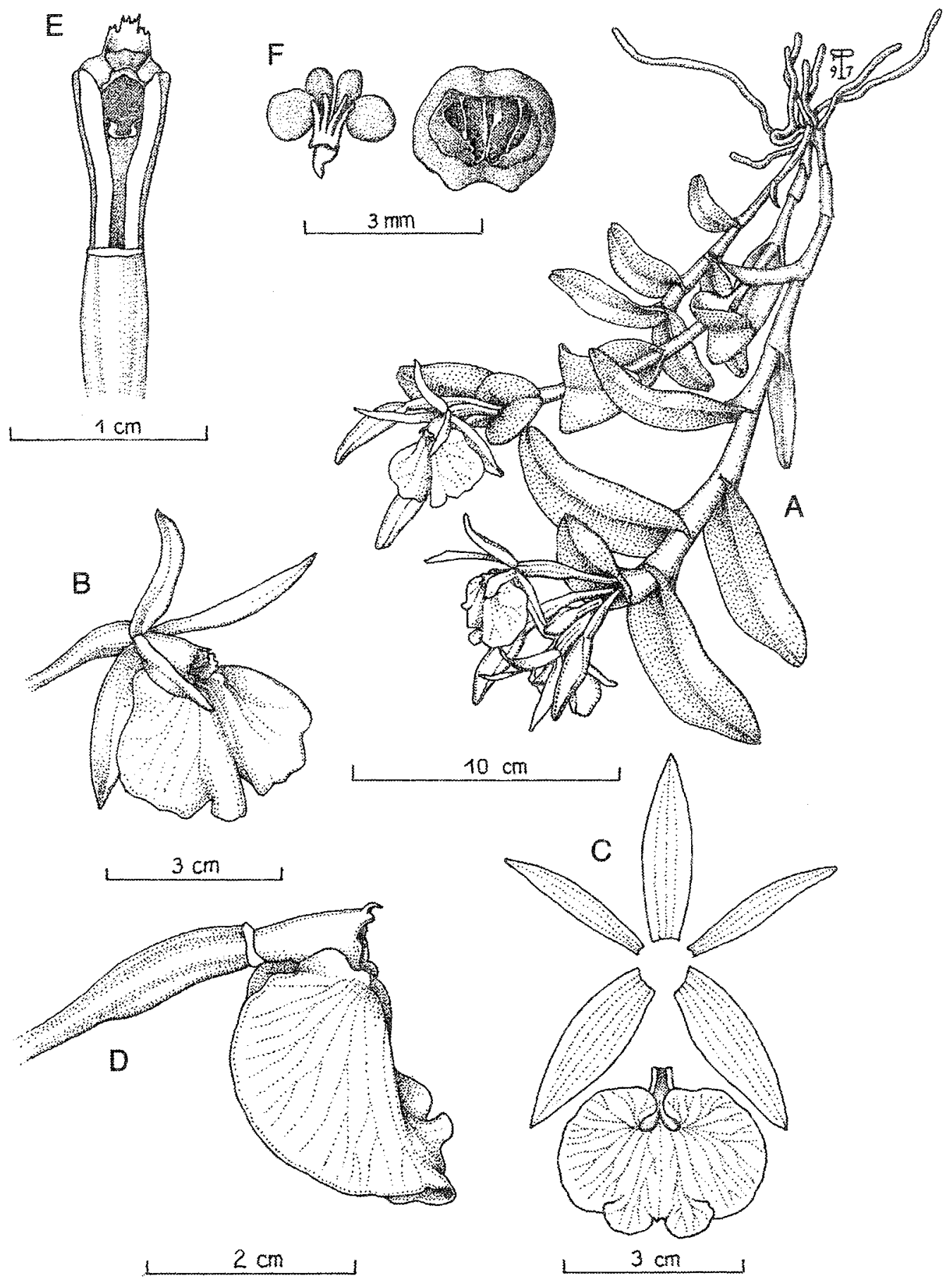

Fig. 16. Epidendrum amparoanum Schltr. A - Habit. B - Flower. C - Column and lip, lateral view (sepals and petals removed). D - Dissected perianth. E - Column, ventral view. F - Pollinaria and operculum. Illustration voucher: F. Pupulin 328. 


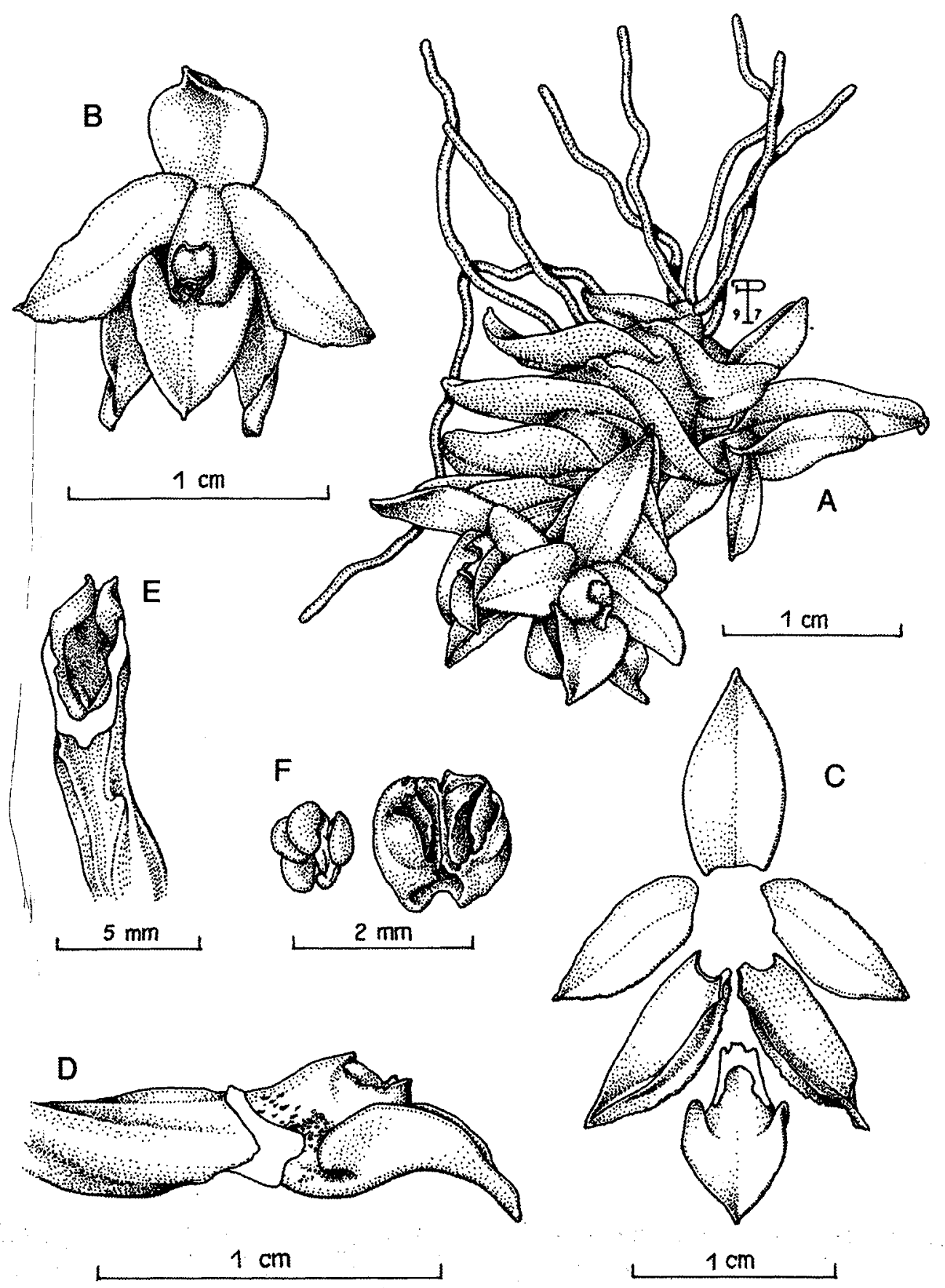

Fig. 17. Epidendrum congestum Rolfe. A - Habit. B - Flower. C - Column and lip, lateral view (sepals and petals removed). D - Dissected perianth. E - Column, ventral view. F - Pollinaria and operculum. Illustration voucher: F. Pupulin 296. 
flexuous, reaching $1 \mathrm{~m}$ or more in lenghth, 0.2 $\mathrm{cm}$ in diameter, the short branches about 10-12 $\mathrm{cm}$ long, leafy toward the apex of new growths, covered with papyraceous sheaths at the base of older stems. Roots fibrous, flexuous, glabrous, produced at the base of the main stem. Leaves linear, flat to subterete, acute, to about $10 \mathrm{~cm}$ long, $0.2-0.4 \mathrm{~cm}$ wide, articulated to the sheaths, deciduous with age. Inflorescence terminal at the apex of lateral branches, 1flowered. Flowers small, yellowish green. Sepals subsimilar, linear-lanceolate, acute, the margins somewhat revolute, 11-15 mm long, 2.5-3 mm wide. Petals oblique, linear-elliptic, acute, $11-13 \mathrm{~mm}$ long, 1.2-1.5 mm wide. Lip unguiculate, the claw adnate to the column, the lamina narrowly lanceolate, canaliculate, acute, fleshy, 9-12 $\mathrm{mm}$ long, $4.5 \mathrm{~mm}$ wide when spread out; disc with a short, V-shaped callus and a median keel extending from the base to the middle of the blade. Column short, stout, adnate to the lip just to the apex, with a cucullate clinandrium, the margins entire, 7 mm long. Pollinia 4, laterally compressed, on a short caudicle. Anther cap hemiglobose, 4celled.

Distribution: From Mexico to Panama, widespread in lowland wet forests.

Parque Nacional Manuel Antonio: Although I have not yet found plants of Epidendrum isomerum within PNMA, Bolaños et al. (1983) recorded it in their list. The species is widespread and relatively common outside the protected area and it may be found southward also in mangrove, where it has been collected from Rio Esquinas in Golfo Dulce (R. Soto s.n., CR!). Rare at PNMA. June.

Phenology: flowering probably in May-

4. Epidendrum nocturnum Jacq., Enum. Syst. Pl. 29. 1760. Epidendrum carolinianum Lam., Encycl. 1: 182. 1783. Nyctosma nocturna Raf., F1. Tellur. 2: 9. 1837. Epidendrum tridens Poepp. \& Endl., Nov. Gen. et Sp. 2: 2. 1838. Epidendrum longicolle Lindl., Bot. reg. 24: misc. 34. 1838. Epidendrum discolor Rich. \& Gal., Ann. Sci. Nat. ser. 3, 3:
22. 1845. Epidendrum spruceanum Lindl., Fol. Orch. Epidendrum 80. 1853. Epidendrum nocturnum var. tridens Cogn. in Mart., Fl. Bras. 3 (5): 136. 1898. Epidendrum buenaventurae Lehm. \& Krzl. in Engler, Bot. Jahrb. Syst. 26: 470. 1899. Phaedrosanthus nocturnus Ktze. in Post \& Ktze., Lex. Gen. Phanerog. 429. 1904. Auliza nocturna Small, Fl. Miami 56. 1913. Epidendrum leucarachne Schltr., Repert. Spec. Nov. Regni Veg. Beih. 7: 136. 1920. Epidendrum tunguraguae Schltr., Repert. Spec. Nov. Regni Veg. Beih. 8: 87. 1921. Epidendrum oliganthum Schltr., Repert. Spec. Nov. Regni Veg. Beih. 9: 90.1921. Epidendrum nocturnum var. panamense Schltr., Repert. Spec. Nov. Regni Veg. Beih. 17: 36. 1922. Amphiglottis nocturna Britt., Sci. Surv. Porto Rico \& Virgin Isl. 5 (2): 200. 1924. (Fig. 18).

Plant epiphytic, erect to pendent, without pseudobulbs, up to about $50 \mathrm{~cm}$ tall. Stems foliaceous, to $45 \mathrm{~cm}$ long, $0.5 \mathrm{~cm}$ in diameter, covered with tubular leaf sheaths. Roots fleshy, flexuous, glabrous. Leaves ellipticoblong, subcoriaceous, acute, $5-11 \mathrm{~cm}$ long, $1.5-3 \mathrm{~cm}$ wide, articulated to the sheaths, deciduous with age. Inflorescence terminal, a short, few- successively flowered raceme, enfolded by $2-3$ papyraceous bracts at the base. Flowers large, fragrant at night, sepals and petals green, the lip white, turning creamy yellow with age. Sepals subequal, narrowly linear, acute to acuminate, $8 \mathrm{~cm}$ long, $0.8 \mathrm{~cm}$ wide. Petals oblique, narrower than sepals, acute, $7.5 \mathrm{~cm}$ long, $0.5 \mathrm{~cm}$ wide. Lip unguiculate, the claw adnate to the column, the lamina prominently 3 -lobed, the midlobe acicular to subfiliform, the lateral lobes broad, obliquely elliptic-ovate, obtuse to retuse, entire lip $6.5 \mathrm{~cm}$ long, $3 \mathrm{~cm}$ wide between the lateral lobes; disc with a pair of short, slightly diverging calli and a central keel running toward the midlobe. Column clavate, stalked, adnate to the lip just to the apex, with a cucullate clinandrium, the margins erose, 22 mm long. Pollinia 4, laterally compressed, on a short caudicle. Anther cap subrhombic, cucullate, 4-celled. 


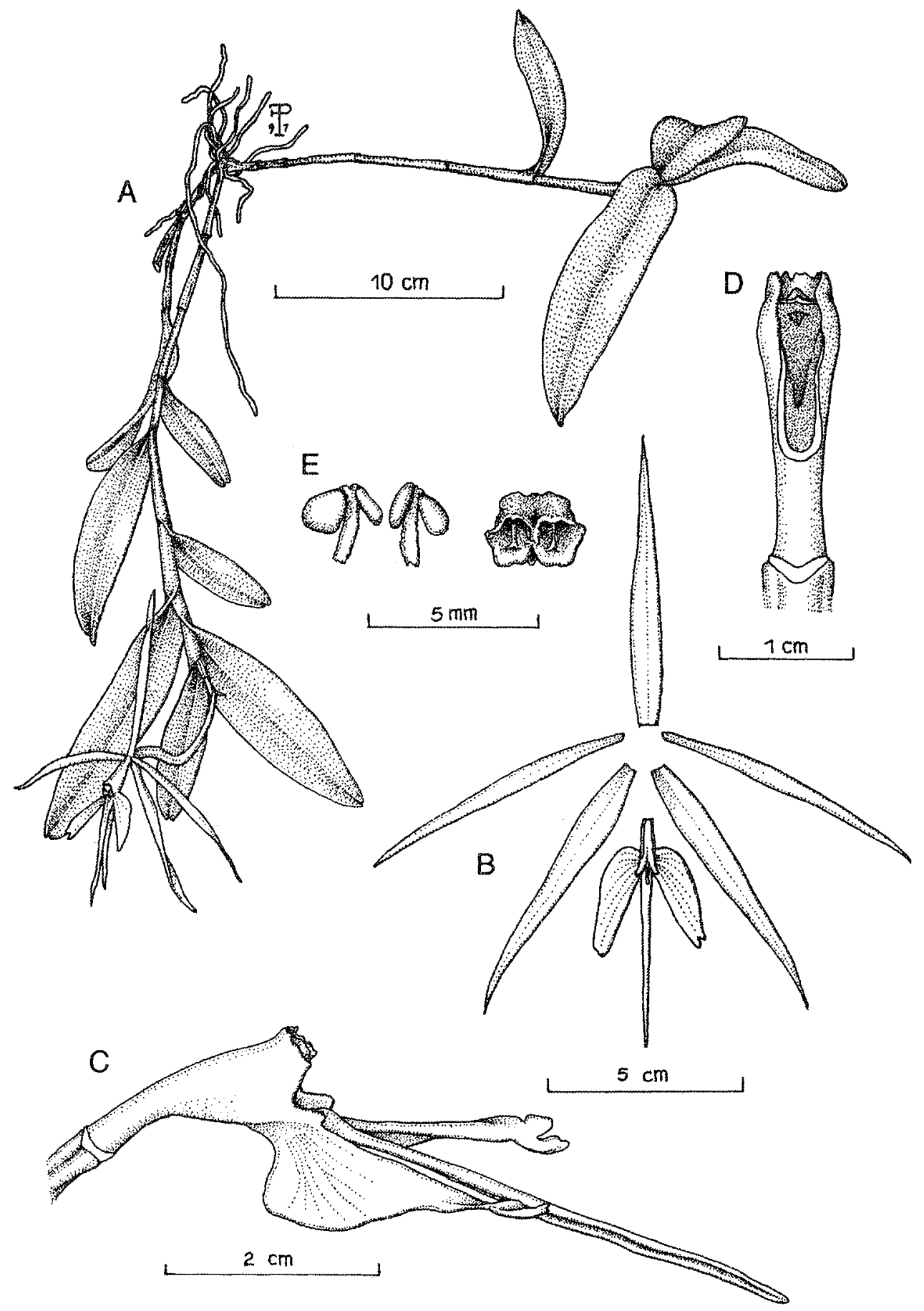

Fig. 18. Epidendrum nocturnum Jacq. A - Habit. B - Column and lip, lateral view (sepals and petals removed). C - Dissected perianth. D - Column, ventral view. E - Pollinaria and operculum. Illustration voucher: F. Pupulin 335. 
Distribution: From Florida to tropical South America and the West Indies, widespread at low elevations.

Parque Nacional Manuel Antonio: The species is widespread within the protected area, where it may be found in lighted situations in secondary forest and on short trees along the sea. It was once much more frequent on Terminalia catappa and Tabebuia rosea trees on the beach at the entrance of the park, but in recent years these populations have been severely reduced for unknown reasons. The species should now be regarded as occasional at PNMA.

Phenology: flowering occurs sporadically throughout the year.

5. Epidendrum sculptum Rchb. F., Bonplandia 2: 89. 1854. Epidendrum colonense Ames, Sched. Orch. 1: 14. 1922. (Fig. 19).

Plant epiphytic, pendent, without pseudobulbs, up to $80 \mathrm{~cm}$ tall. Stems foliaceous, simple or commonly manybranched, somewhat flexuous, about $0.5-0.8$ $\mathrm{cm}$ in diameter, densely leaved, covered with papyraceous sheaths at the base of older stems. Roots fibrous, flexuous, glabrous, produced at the base of the main stem, about $1 \mathrm{~mm}$ in diameter. Leaves elliptic-oblong, fleshy, obtuse to retuse, $2-4.9 \mathrm{~cm}$ long, $0.5-1.2 \mathrm{~cm}$ wide, articulated to the sheaths, deciduous with age. Inflorescence terminal at the apex of laterai branches, 1-flowered or commonly 2 flowered. Flowers small, yellowish green, fleshy, scented. Sepals subsimilar, lanceolate to linear-oblong, obtuse, the margins somewhat revolute, $9-10.5 \mathrm{~mm}$ long, $2.5-3 \mathrm{~mm}$ wide. Petals oblique, linear-oblong, obtuse, 10 $\mathrm{mm}$ long, $2 \mathrm{~mm}$ wide. Lip unguiculate, the claw adnate to the column, the lamina 3-lobed, ovate-lanceolate, cordate at the base; the lateral lobes elliptic, erect, reaching about the middle of the lip; midlobe lanceolate, apiculate; disc with a pair of short, mamillate calli at the base of the lateral lobes and two low ridges extending to the middle of the midlobe; entire lip $11 \mathrm{~mm}$ long, $5.5 \mathrm{~mm}$ wide when spread out. Columm short, stout, adnate to the lip near to the apex, with a cucullate, 3-toothed clinandrium, $4 \mathrm{~mm}$ long. Pollimia 4 , on a short caudicle. Anther cap cucullate, 4-celled.

Distribution: From Honduras to Ecuador and the Guyanas, local in lowland forests.

Parque Nacional Manuel Antonio: The record is based on a single collection from a high, main branch of Pithecellobium saman along a grassland and no other observations were made in the neighbouring areas. The species is rare at PNMA.

Phenology: flowering occurs from December to February.

6. Epidendrum sî́nfordianum Batem., Orch. Mex. \& Guat. t. 11. 1838. Epidendrum basilare Kl., Allg. Gartenz. 11: 193. 1843. Epidendrum cycnostalix Rchb. f., Bot. Zeit. 10: 731. 1852. Epidendrum stamfordianum var. pictum Lemaire, Jard. Fl. 3: t. 251. 1852. Epidendrum stamjordianum var. parviflorum Regel, Ind. Sem. Hort. Petro. 19. 1856. Epidendrum stanfordianum var. wallacei Rchb.f., Gard. Chron. ser. 3, 1: 543. 1887. Epidendrum stamfordianum var. leeanum Rchb.f., Gard. Chron. ser. 3, 3: 521. 1888. Epidendrum stamfordianum var. lawrenceanum hort. ex Stein, Orchideenb. 240. 1892. Psilantheum basilare K1. ex Stein., Orchideenb. 238. 1892. Auliza stamfordianum (Batem.) Brieg., Die Orchideen 3. Aufl. 1 (9): 548. 1977. (Fig. 20).

Plant epiphytic, cespitose, erect, to about $50 \mathrm{~cm}$ tall. Roots fleshy, flexuous, glabrous. Pseudbulbs stalked, fusiform, enfolded by many large bracts becoming papyraceous with age, $8-28 \mathrm{~cm}$ long, $1.5-2.2 \mathrm{~cm}$ in diameter, 2 to 4-leaved near the apex. Leaves rather variable, oblong-elliptic to ligulate or oblanceolate, obtuse, coriaceous, $10-22 \mathrm{~cm}$ long, 2.5-6.5 cm wide. Inflorescence lateral from a short shoot along the rhizome, an erect to slightly arcuate, simple or rarely paniculate raceme, usually many-flowered raceme to 50 $\mathrm{cm}$ long, enfolded by 2-3 triangular bracts. Tlowers medium sized, showy, sepals and petals greenish yellow marked with dark 


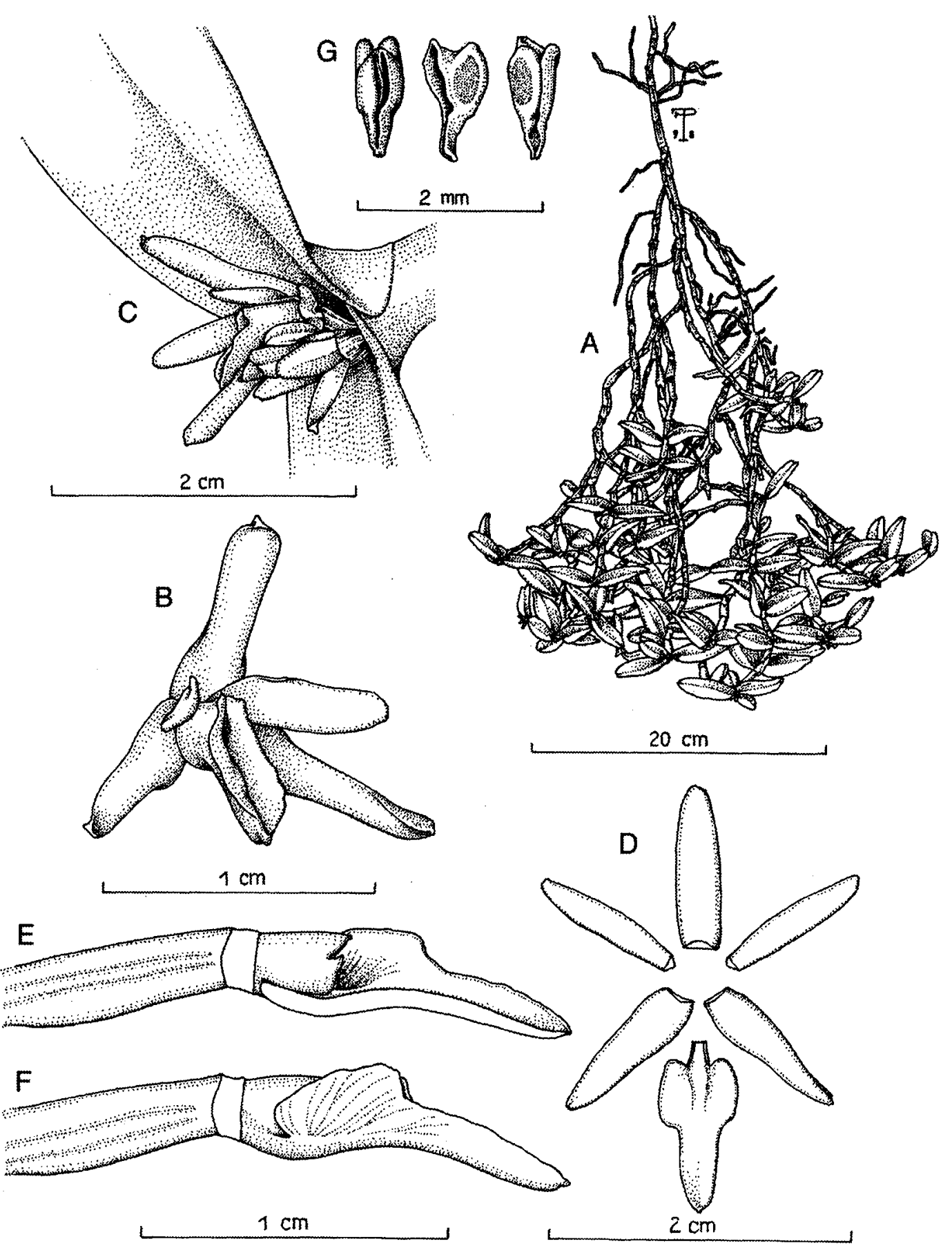

Fig. 19. Epidendrum sculptum Rchb.f. A - Habit. B - Flower. C - Column and lip, lateral view (sepals and petals removed). D - Dissected perianth. E - Column, ventral view. F - Pollinaria and operculum. Illustration voucher: F. Pupulin 373. 

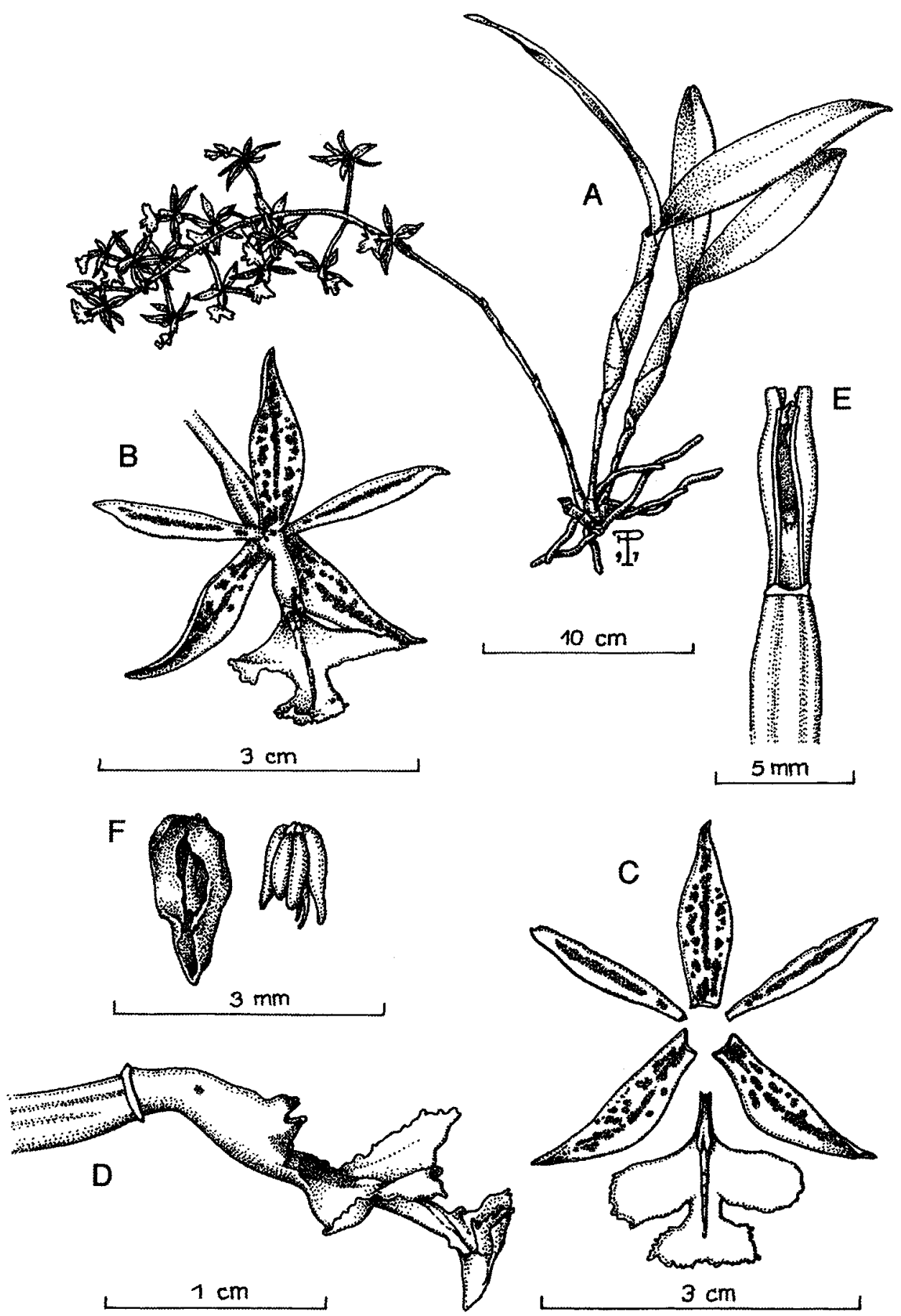

Fig. 20. Epidendrum stamfordianum Batem. A - Habit. B - Flower. C - Column and lip, lateral view (sepals and petals removed). D - Dissected perianth. E - Column, ventral view. F - Operculum and pollinaria. Illustration voucher: F. Pupulin 370 . 
purple, the lip white variously spoted or suffuse with lilac to purple. Sepals subequal, ellipticoblanceolate, acute, the lateral sepals falcate, concave near the apex, $1.8-2 \mathrm{~cm}$ long, $0.5 \mathrm{~cm}$ wide. Petals oblique, linear-oblong, acute, 1.8 $\mathrm{cm}$ long, $0.3 \mathrm{~cm}$ wide. Lip unguiculate, the claw adnate to the column, the lamina prominently 3-lobed, the midlobe transversely oblong, with a short claw at the base, crenulate to serrulate; the lateral lobes broad, subqadrateelliptic, rounded, crenulate; disc provided with a short bilobed callus at the base and a median, low keel running to the middle of the midlobe; the entire lip $1.7 \mathrm{~cm}$ long, $2 \mathrm{~cm}$ wide between the lateral lobes. Column clavate, stalked, adnate to the lip just to the apex, with a cucullate, 3-toothed clinandrium, $9 \mathrm{~mm}$ long. Pollinia 4, laterally compressed, in two pairs of different size, on a short caudicle. Anther cap cucullate, lanceolate, 4-celled.

Distribution: Widespread at low elevations in Central and northern South America, from Mexico to Panama, Colombia and Venezuela.

Parque Nacional Manuel Antonio: Within the park the species is mainly restricted to the main branches and trunks of relictual, large Pithecellobium spp. trees in pastures. Here it is not uncommon to find hugues specimens with more than 20 large, leafy pseudobulbs, each one exceeding $50 \mathrm{~cm}$ in length. Frequent at PNMA. April.

Phenology: flowering occurs in March-

\section{IONOPSIS Kunth}

Small, cespitose, epiphytic herbs with inconspicuous stems, 1-2-foliate at apex, subtended by foliaceous sheaths. Leaves conduplicate, coriaceous to subterete. Inflorescence lateral, a few- to many-flowered, erect to arching raceme or panicle. Flowers small, white to pale lilac somewhat striped with rose-purple. Sepals and petals spreading; the lateral sepals connate producing at the base a short sac; lip simple, clawed, adnate to the base of the column, the lamina exceeding the sepals. Column erect, nearly terete, footless, sometimes provided with rudimentary wings. Pollinia 2, waxy.

A neotropical genus of 3 to 5 species, often restricted to the twigs of the host trees.

1. Ionopsis satyrioides (Sw.) Rchb.f., Walp. Ann. Bot. Syst. 6: 683. 1861. Epidendrum satyrioides Sw., Prod. 123. 1788. Dendrobium testiculatum Sw., Nov. Act. Upsal. 6: 83, 1799. Ionopsis testiculata (Sw.) Lindl., Gen. \& Sp. Orch. Pl. 193. 1833. Ionopsis teres Lindl, Bot. Reg. 24, misc. 95. 1838. (Fig. 21).

Plant epiphytic, mainly on twigs and small branches, to about $15 \mathrm{~cm}$ tall, with abbreviate rhizome. Roots fibrous, flexuous. Pseudobulbs inconspicuous, elliptic to subcylindric, laterally flattened, to $4 \mathrm{~mm}$ long, about $2 \mathrm{~cm}$ wide, nearly completely hidden by 2-5 leafy sheaths, monophyllous. Leaves terete, linear to linear-attenuate, acute, to 10 $12 \mathrm{~cm}$ long, about $0.3 \mathrm{~cm}$ in diameter. Inflorescence a lateral, successively flowered raceme, to $16 \mathrm{~cm}$ long (but usually shorter). Flowers small, white with obscure rose stripes. Sepals campanulate, not completely spreading. Dorsal sepal lanceolate-elliptic, acute, to $9 \mathrm{~mm}$ long, 3-4 $\mathrm{mm}$ wide. Lateral sepals elliptic-lanceolate, acute, connate at the base for about one third of their lenghth, to 10 $\mathrm{mm}$ long, $3.5 \mathrm{~mm}$ wide. Petals ovate-elliptic, obtuse, minutely mucronate, $10 \mathrm{~mm}$ long, 3.5 $\mathrm{mm}$ wide. Lip clawed, cuneate, obtuse to retuse, slightly concave toward the apex, with two rudimentary auricles near the base, the disc provided with two diverging, thick keels; entire lip $11 \mathrm{~mm}$ long, $5 \mathrm{~mm}$ wide. Column short, with two obscure wings, to $3 \mathrm{~mm}$ long. Pollinia 2, subspherical, on a ligulate stipe; viscidium elliptic. Anther cap hemiglobose, 2-celled.

Distribution: From Costa Rica to northern South America, widespread in wet forests and orchards.

Parque Nacional Manuel Antonio: Plants of Ionopsis satyrioides have so far escaped 


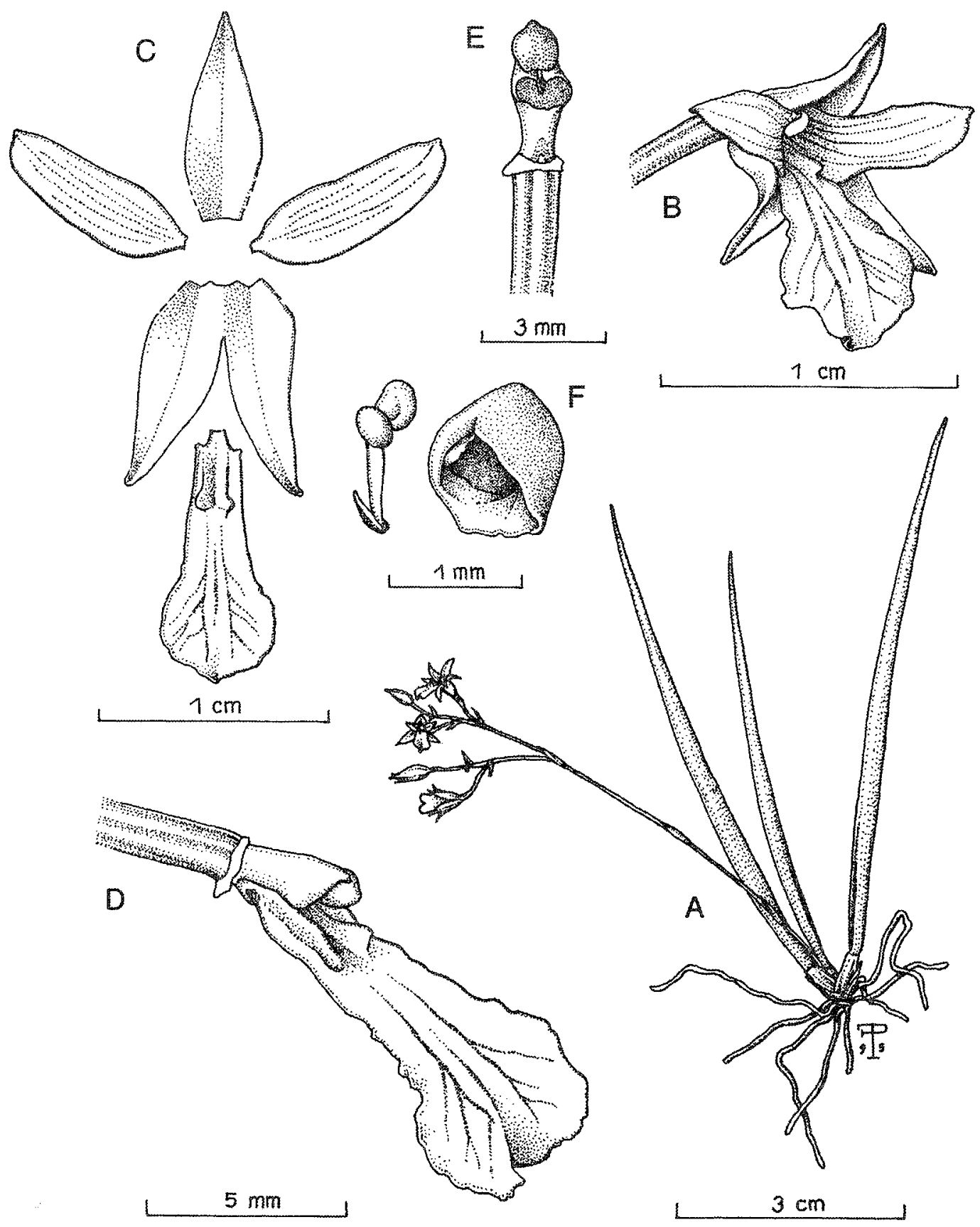

Fig. 21. Ionopsis satyrioides (Sw.) Rchb.f. A - Habit. B - Flower. C - Column and lip, three quarter view (sepals and petals removed). D - Dissected perianth. E - Column, ventral view. F - Pollinarium and operculum. lllustration voucher: $F$. Pupulin 309. 
attention at PNMA and my collection is from the low hills northern to the park. However, the species is a common inhabitant of disturbed habitats and orchards (mainly on Citrus and Psidium spp.) and its presence within the protected area is likely. It should be considered rare at PNMA.

Phenology: flowering occurs from September to December.

\section{LEOCHILUS Knowles and Westcott}

Small, cespitose, epiphytic herbs with ovoid, laterally compressed pseudobulbs, 1- 2foliate at apex, subtended by 1-2 foliaceous sheaths. Leaves conduplicate, elliptic to oblong, subcoriaceous. Inflorescence lateral, a few- to many- successively flowered raceme or panicle. Flowers small, greenish-yellow usually stripped with brown. Sepals and petals spreading; the lateral sepals variously connate; lip simple or 3-lobed, provided near the base with a fleshy callus serving as an open nectary filled with oil. Column erect, nearly terete, footless, often provided with stigmatic arms. Pollinia 2, waxy.

A neotropical genus of about 9 species, sometimes restricted to the twigs of the host trees.

1. Leochilus scriptus (Scheidw.) Rchb.f., Xenia Orchid. 1(1): 15, 1854. Cryptosanus scriptus Scheidw., Allg. Gartenzeit. 11: 101, 1843. Leochilus herbaceus Lindl., Bot. Reg. 30: Misc. 90, 1844. Cryptosaccus scriptus Scheidw. ex Rchb.f., Xenia Orchid. 1(1): 15, 1854. Oncidium herbaceum (Lindl.) Rchb.f., Ann. Bot. Syst. 6: 772, 1863. Oncidium scriptum (Scheidw.) Rchb.f., Ann. Bot. Syst. 6: 772, 1863. Leochilus major Schltr., Repert. Spec. Nov. Regni Veg. Beih. 15: 209, 1919. Leochilus powellii Schltr., Repert. Spec. Nov. Regni Veg. Beih. 17: 81, 1922. Leochilus retusus Schltr., Repert. Spec. Nov. Regni Veg. Beih. 19: 256, 1923. (Fig. 22).

Plant epiphytic, to about $15 \mathrm{~cm}$ tall, with abbreviate rhizome. Roots fleshy, white with green vegetative apex. Pseudobulbs ovate to elliptic, laterally flattened, to $3.2 \mathrm{~cm}$ long, about $1.5 \mathrm{~cm}$ wide, basally covered by $2-3$ leafy sheaths, monophyllous. Leaf conduplicate, linear to linear-elliptic, obtuse, slightly emarginate, to $10-12 \mathrm{~cm}$ long, $1.2-2$ $\mathrm{cm}$ wide. Inflorescence basal, to $16 \mathrm{~cm}$ long, 1- to many-flowered (mainly 3-flowered); peduncle terete; bracts triangular-lanceolate, acute, about $0.7 \mathrm{~cm}$ long. Flowers small, greenish yellow spotted with purple red. Dorsal sepal elliptic-obovate, acute, to 5.5 $\mathrm{mm}$ long, $0.3-0.4 \mathrm{~mm}$ wide. Lateral sepals obliquely elliptic-obovate, acute to slightly apiculate, to $7 \mathrm{~mm}$ long, $0.3 \mathrm{~mm}$ wide. Petals linear, apiculate, to 6-7 mm long, about $3 \mathrm{~mm}$ wide. Lip obovate, obtuse to retuse, flat, with a small, concave nectary at the base provided with pilose margins; callus trapezoidal, with a central groove, papillose; entire lip $9 \mathrm{~mm}$ long, $5 \mathrm{~mm}$ wide. Column short, with a pair of triangular, acute stigmatic arms, to $2.5 \mathrm{~mm}$ long. Pollinia 2, subspherical, on a short, ligulate stipe; viscidium peltate, brown. Anther cap hemiglobose, 2-celled.

Distribution: From Mexico to Panama and northern South America. Common at lower elevations on Pacific coasts in Central America.

Parque Nacional Manuel Antonio: Epiphytic on Croton sp. at the edge of secondary forest. Plants of $L$. scriptus were found growing in medium-shaded conditions, on little branches and twigs without any mosses. The species is rare at PNMA.

Phenology: flowering mainly occurs from December through February and March, but plants may flower also in other months.

\section{LOCKHARTIA Hook.}

Cespitose, epiphytic herbs without pseudobulbs, the foliaceous stems erect or pendent, completely envolved by the distichously imbricating leaves. Leaves short, laterally flattened, triangular, coriaceous. Inflorescence lateral, few- to many- 

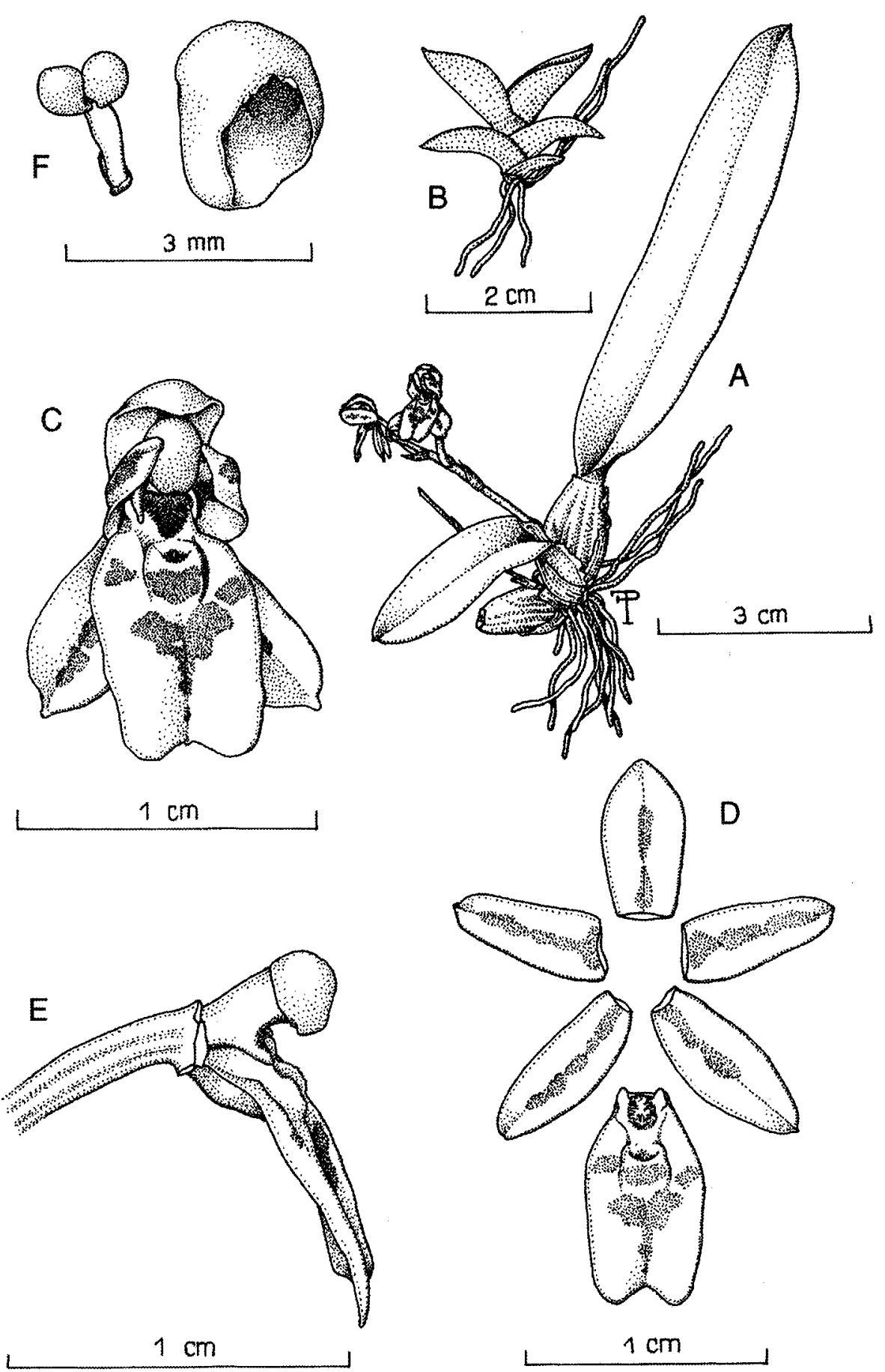

Fig. 22. Leochilus scriptus (Scheidw) Rchb. f. A - Habit. B - Juvenile plant. C - Flower. D - Dissected perianth. E - Column and lip, lateral view (sepals and petals removed). F - Pollinarium and operculum. Illustration voucher: F. Pupulin 374. 
successively flowered raceme or panicle, emerging from the axils of the leaves, the pedicel often covered with conspicuous membranaceous bracts. Flowers small, yellow or white, usually blotched with reddish brown on the lip. Sepals subequal, free, spreading or sometimes reflexed; petals usually broader; lip simple or 3-lobed, the lateral lobes rounded to lnear, the midlobe variously 2- to 4-lobed, provided near the base with a complex callus. Column short, footless, provided with large apical wings. Pollinia 2, waxy.

A neotropical genus of about 30 species, usually found on trunks and large branches of trees.

1. Lockhartia pandurata Pupulin sp. nov. Species Lockhartiae micranthae Rchb.f similis, sed lobis lateralibus labelli subtriangularibus rotundatis multo brevioribus et caespite tomentoso in disco labelli differt. Type: Costa Rica. Prov. Puntarenas: Aguirre, Parque Nacional Manuel Antonio, in disturbed primary forest, $80 \mathrm{~m}, 11$ July 1995, F. Pupulin 313 (holotype,USJ; isotype, CR). (Fig. 23).

Herb epiphytic, cespitose, without pseudobulbs, to about $25 \mathrm{~cm}$ tall. Roots filiform, $0.8 \mathrm{~mm}$ in diameter. Stems foliaceous, erect, becoming pendent with age, 10 to $25 \mathrm{~cm}$ long, $1-1.5 \mathrm{~cm}$ wide. Leaves distichous, imbricate, triangular in lateral view, apically obtuse to rounded, $1.4-1.5 \mathrm{~cm}$ long, lateral width $0.6-0.7 \mathrm{~cm}$. Inflorescence a terminal or subterminal raceme of few flowers, $1.3-1.5 \mathrm{~cm}$ long, provided with 1-2 triangularovate, acute bracts, $2 \mathrm{~mm}$ long, $1.6 \mathrm{~mm}$ wide; the ovary with pedicel about $8 \mathrm{~mm}$ long; floral bracts suborbicular, acute, $5.3 \mathrm{~mm}$ long, 3.8 $\mathrm{mm}$ wide. Flowers small for the genus, $6 \mathrm{~mm}$ in width, pale yellow with pale red-brown spots on lip and column. Dorsal sepal suborbicular, apiculate, concave, $3 \mathrm{~mm}$ long, $2.5 \mathrm{~mm}$ wide. Lateral sepals ovate-elliptic, apiculate, concave, $3.2 \mathrm{~mm}$ long, $2 \mathrm{~mm}$ wide. Petals elliptic, slightly concave near the apex, $3.4 \mathrm{~mm}$ long, $2.2 \mathrm{~mm}$ wide. Lip 3-lobate, pandurate, $3.5 \mathrm{~mm}$ long, $3.5 \mathrm{~mm}$ wide $(2.8 \mathrm{~mm}$ wide between the lateral lobes); the lateral lobes subtriangular, rounded, $0.5 \mathrm{~mm}$ long, 1 $\mathrm{mm}$ wide; the midlobe widely obovate to subrhombic, emarginate, with a short, rounded apicule; the disk with a trapeziform callus, distally bilobed, provided at the base with a tuft of distinct papillae, and three irregular rows of rounded, flat tubercles in front of the callus running just below the half of the lip. Column short, with two triangulardolabriform wings, $1.3 \mathrm{~mm}$ long, $1.9 \mathrm{~mm}$ wide. Anther cap cucullate, papillose, 2celled. Pollinia 2, pyriform-obovate, on two linear stipes; viscidium subquadrate, white.

Paratypes: Costa Rica. Prov. Puntarenas: Aguirre, Parque Nacional Manuel Antonio, F. Pupulin 324 (SEL, Herb. Pupulin).

Etymology: Named in reference to the pandurate lamina of the lip.

Distribution: Known only from Costa Rican central Pacific lowlands.

Parque Nacional Manuel Antonio: Epiphytic on lower canopy and trunks; just to the seashore on the high branches of tall trees. Common at PNMA.

Phenology: flowering occurs in December-January.

Lockhartia pandurata is closely allied to L. micrantha, with which it has been confused in herbarium specimens. In his key to Costa Rican and Panamian Lockhartia species, Dressler (1993) divided the genus in two groups primarily based on the presence or absence of definite lateral lobes of the lip, but $L$. pandurata fills the gap between the two groups. In $L$. pandurata the lateral lobes are reduced to very short, subtriangular, rounded ear-like projections.

\section{MAXILLARIA Ruiz \& Pav.}

Epiphytic or lithophytic herbs with short to elongate, erect to pendent stems, with or without clustered to distant pseudobulbs, 1- 3foliate at apex. Leaves conduplicate, thin to coriaceous, persistent. Inflorescence a scape from the base of pseudobulbs or lateral from leaf axils or from the developing new growth, 

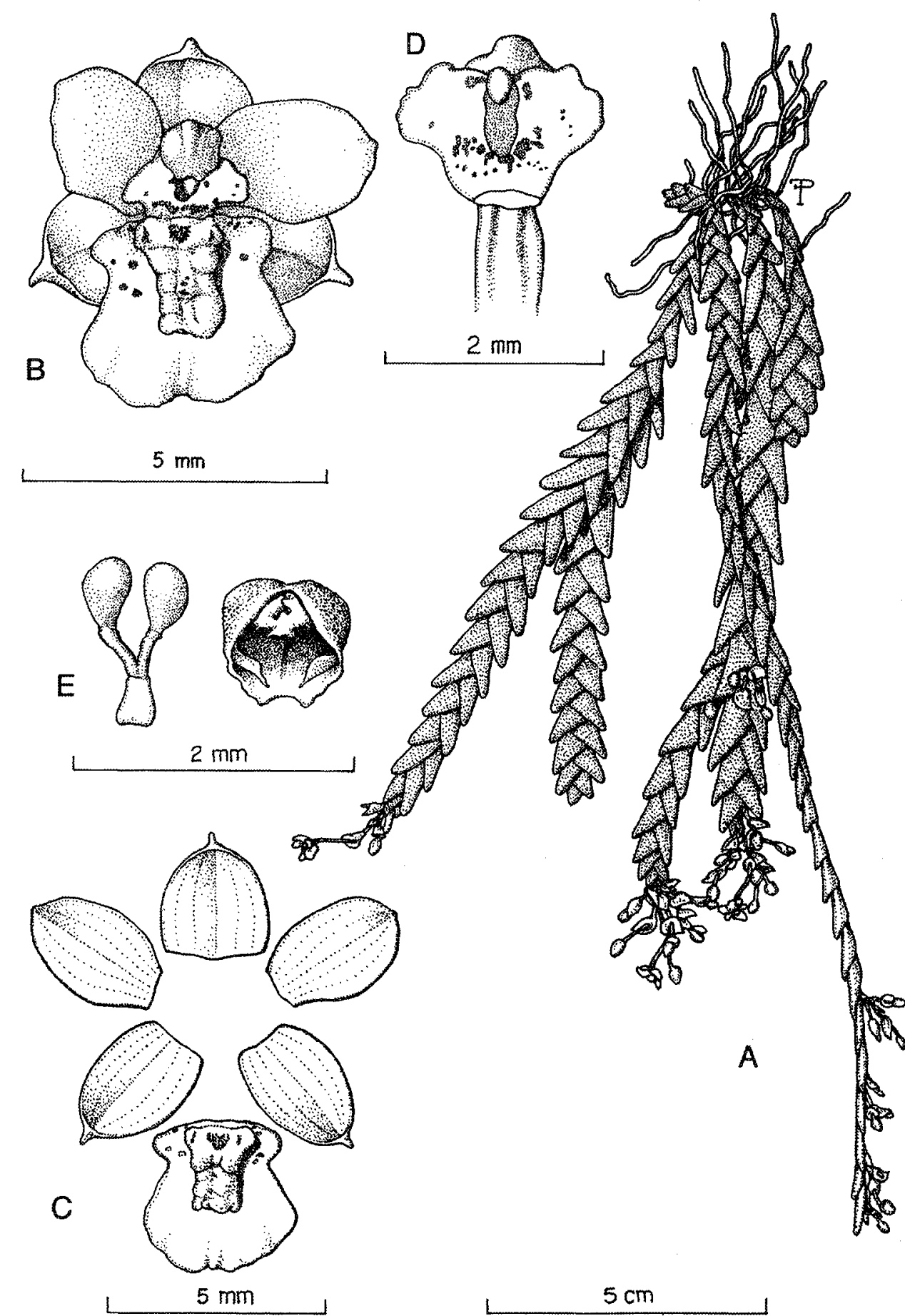

$5 \mathrm{~cm}$

Fig. 23. Lockhartia pandurata Pupulin. A - Habit. B - Flower. C - Dissected perianth. D - Column, ventral view. E Pollinarium and operculum. Illustration voucher: $F$. Pupulin 313. 
1 to many. Flowers small to large. Sepals and petals spreading; the lateral sepals sometimes connate, often forming short mentum with the column base; lip simple or 3-lobed, articulated with or adnate to the column, the lateral lobes erect, the midlobe spreading or reflexed, usually provided at the base with a fleshy callus. Column erect, nearly terete, with or without a conspicuous foot, rarely winged. Pollinia 4, waxy.

A neotropical genus of some 600 mainly poorly known species, widespread from Mexico to Bolivia and Brazil, and the West Indies.

1. Maxillaria crassifolia (Lindl.) Rchb.f., Bonpl. 2: 16, 1854. Heterotaxis crassifolia Lindl., Bot. Reg. 12: t. 1028, 1826. Dicrypta baueri Lindl., Gen. et Spec. Orch. Pl, 44, 1830. Dicrypta crassifolia Lindl. ex Loud. Hort. Brit. Suppl. 3: 536, 1839. Epidendrum sessile Swartz, Prodr. Regn. Veg. Ind. Occ. 122: 1878, non Maxillaria sessilis Lindl. Maxillaria sessilis Fawc. \& Rendle, Fl. Jam. 1: 120, 1910, non Lindl. Maxillaria gatunensis Schltr., Fedde Rep. Sp. Nov. Beih. 17: 68, 1922. (Fig. 24).

Plant epiphytic, cespitose, pendent, with a short rhizome, to about $35 \mathrm{~cm}$ tall. Roots filiform, glabrous. Pseudobulbs oblong, inconspicuous, monophyllous, subtended by 2 3 distichously imbricating, fleshy, foliaceous sheaths, to $3 \mathrm{~cm}$ long, about $1.5 \mathrm{~cm}$ wide. Leaves coriaceous, linear to linear-oblong, obtuse to subacute, forming at the base a more or less complanate petiole, $7-35 \mathrm{~cm}$ long, 1.4$2.8 \mathrm{~cm}$ wide. Inflorescence produced from the axils of the upper leaves, generally 1-flowered, with a short peduncle 1 to $2.2 \mathrm{~cm}$ long, provided by a scarious bract. Ovaries pedicellate, subclavate, about $1 \mathrm{~cm}$ long. Flowers of moderate size, pale yellow, the lip marked with purple. Dorsal sepal oblongelliptic to lanceolate, subacute, conspicuously concave, fleshy, $17 \mathrm{~mm}$ long, $6.5-7 \mathrm{~mm}$ wide. Lateral sepals obliquely ovate-oblong, subacute, dorsally carinate, $16 \mathrm{~mm}$ long, $6 \mathrm{~mm}$ wide, adnate to the column, forming an inconspicuous, rounded mentum. Petals linear-oblanceolate, acute, curved, $13 \mathrm{~mm}$ long, $4 \mathrm{~mm}$ wide. Lip obscurely 3-lobed, elliptic-lanceolate, contracted at the base and articulate with the column foot, to $16 \mathrm{~mm}$ long, $9 \mathrm{~mm}$ wide when spread out; lateral lobes rounded, erect; midlobe subobtuse, thickened and farinose to minutely papillose; disk with a ligulate, fleshy, thickened, farinose callus. Column elongate, arcuate, semiterete, to 12 $\mathrm{mm}$ long, produced at the base into a short foot. Pollinia 4, in two different sized pairs, on a short, rounded, basally dilated stipe. Anther cap cucullate, glabrous, 1-celled.

Distribution: A widespread and rather common species ranging from Florida, Mexico, through Central America, to Panama, the Caribbeam Islands, Venezuela, Brazil and Colombia.

Parque Nacional Manuel Antonio: Epiphytic on Hymenaea courbaril (guapinol) and Cynometra hemitomophylla (guapinol negro) trees mainly in primary or mature secondary forest. Plants are generally found on large trunks in medium shaded conditions. Occasional at PNMA.

Phenology: flowering occurs throughout the year.

2. Maxillaria neglecta (Schltr.) L.o. Williams, Ann. Missouri Bot. Gard. 29: 348. 1942. Ornithidium anceps Rchb.f., Beitr. Orch. Centr-Amer. 75. 1866, non Maxillaria anceps Ames \& C. Schweinf. Ornithidium neglectum Schltr., Fedde Rep. Sp. Nov. Beih. 19: 242, 1923. (Fig. 25).

Plant epiphytic, pendent, with elongate, sometimes branching rhizome, to $50 \mathrm{~cm}$ tall. Roots filiform, glabrous. Pseudobulbs ligularelliptic to widely elliptic, ancipitous, usually very distant, monophyllous, $1.5-3 \mathrm{~cm}$ long, about $0.7-1.5 \mathrm{~cm}$ wide, the long internodes enveloped in closely imbricating, papery bracts. Leaves subcoriaceous, ligular, acute, $5.5-12 \mathrm{~cm}$ long, $1.3-1.9 \mathrm{~cm}$ wide, forming at the base a short petiole. Inflorescences produced from the base of the pseudobulb, 1flowered, short scapes produced in dense fascicles, about $1 \mathrm{~cm}$ long, partially hidden by 

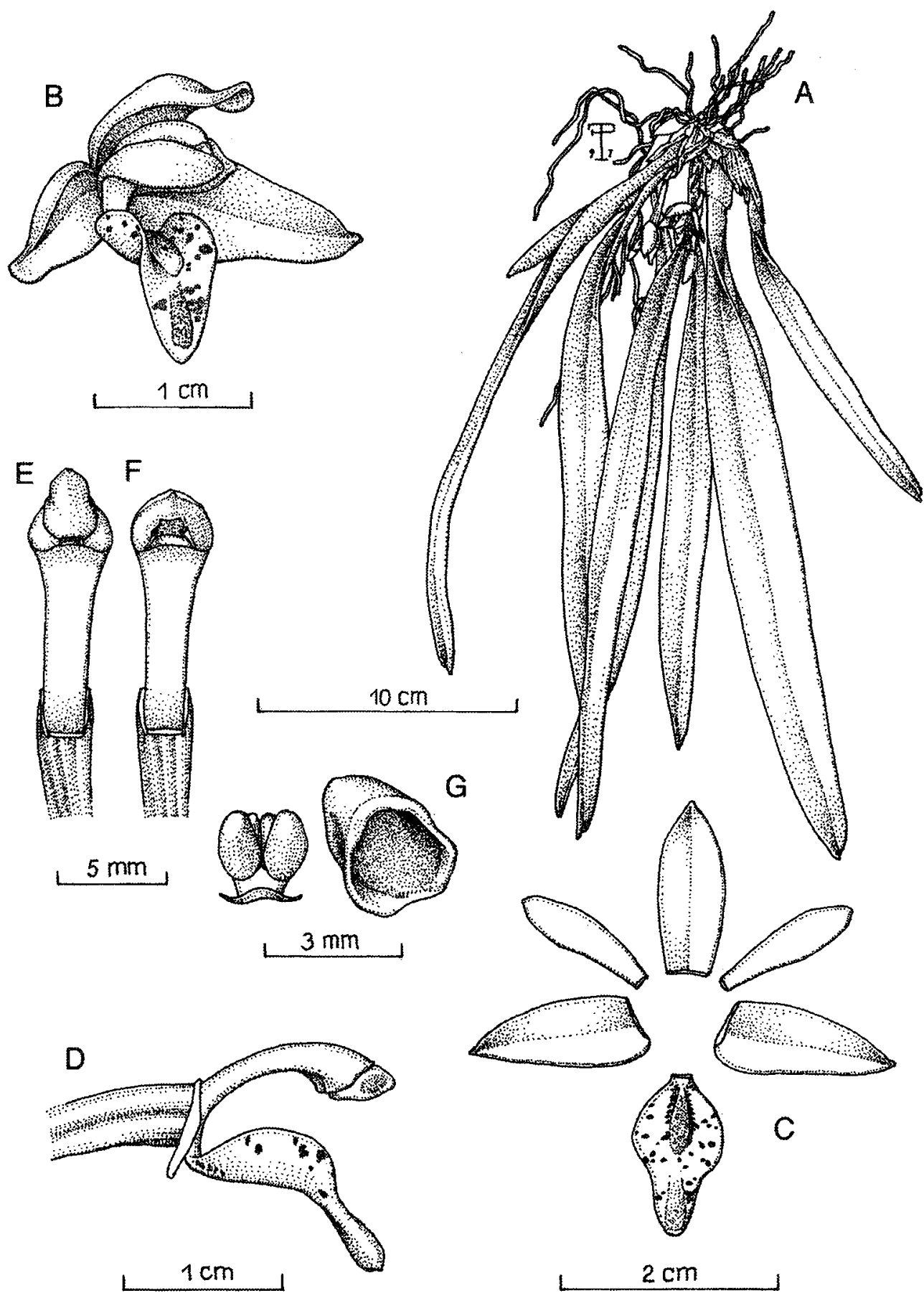

Fig. 24. Maxillaria crassifolia (Lindl.) Rchb.f. A - Habit. B - Flower. C - Dissected perianth. D - Column and lip, lateral view. E - Column, ventral view. F - Column, ventral view, anther removed. G - Pollinarium and operculum. Illustration voucher: F. Pupulin 312. 

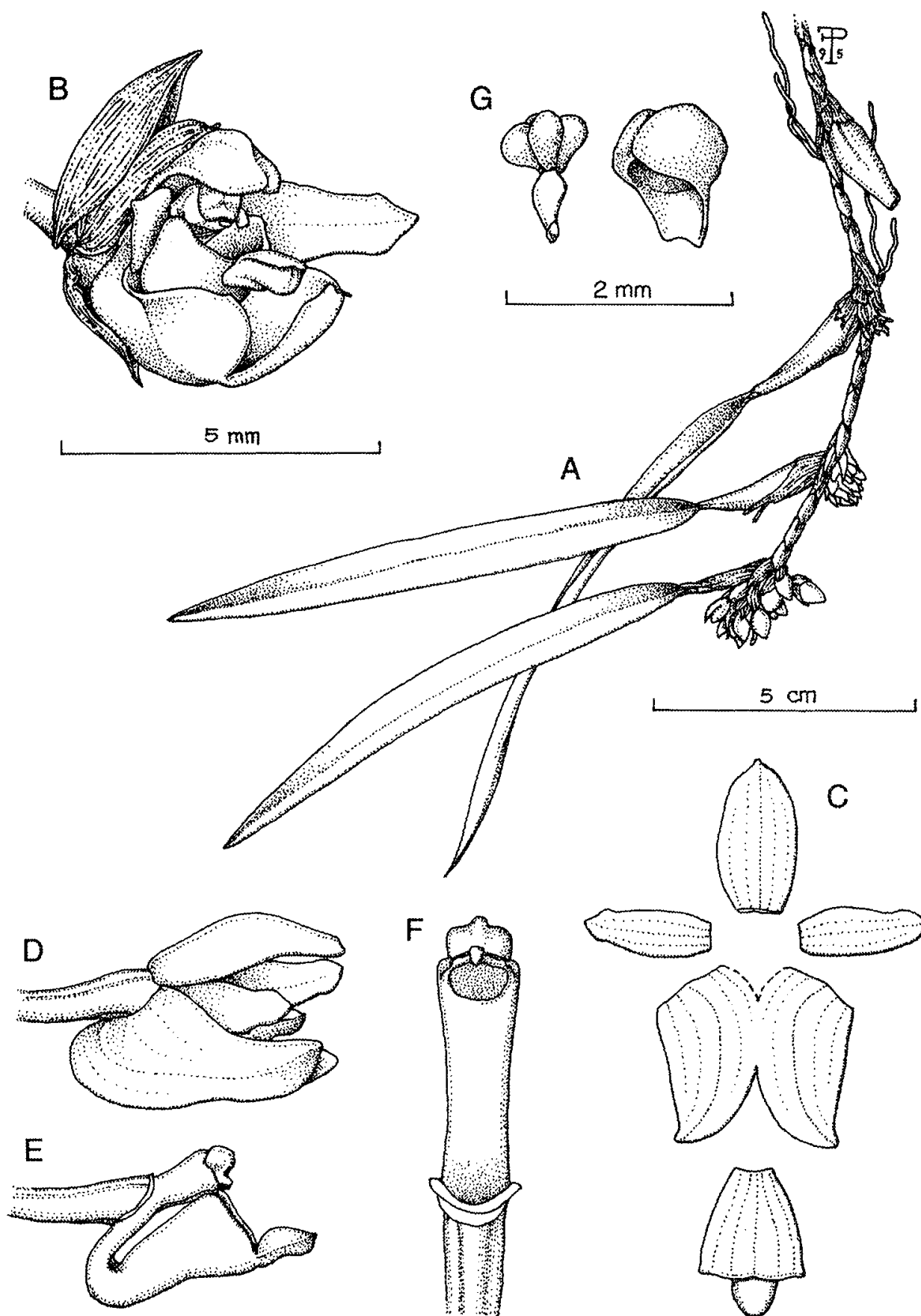

$\mathrm{F}$
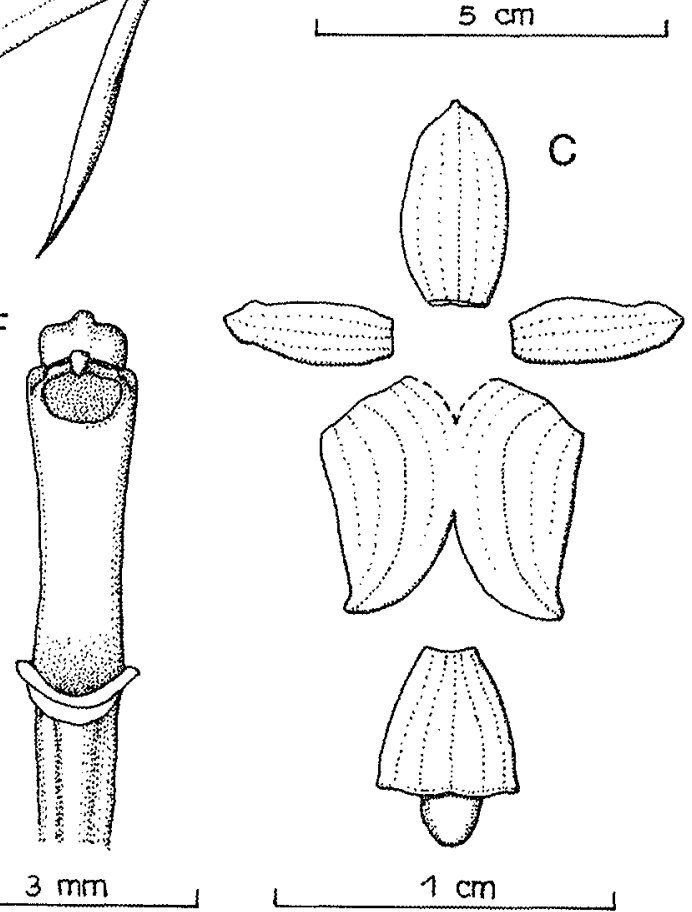

$5 \mathrm{~mm}$
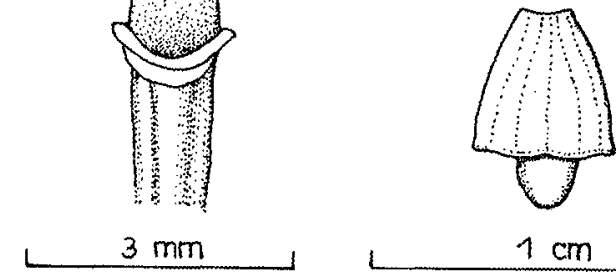

$1 \mathrm{~cm}$

Fig. 25. Maxillaria neglecta (Schltr.) L.O. Williams. A - Habit. B - Flower. C - Dissected peranth. D - Flower, lateral view. E - Column and lip, lateral view. F - Column, ventral view. G - Pollinarium and operculum. Illustration voucher: F. Pupulin 363. 
short glumaceous bracts. Flowers small, white, the lip with yellow midlobe. Dorsal sepal elliptic-ovate, subacute, conspicuously concave, fleshy, $6 \mathrm{~mm}$ long, $3 \mathrm{~mm}$ wide. Lateral sepals ovate, somewhat falcate subacute, dorsally carinate, connate at the base to produce a rounded mentum, 6-7 $\mathrm{mm}$ long, 4 $\mathrm{mm}$ wide. Petals oblong-ligular, subacute, 5-6 $\mathrm{mm}$ long, about $2 \mathrm{~mm}$ wide. Lip unguiculate, 3-lobed, the claw continuous with the column foot, then geniculate, to $6 \mathrm{~mm}$ long, $4 \mathrm{~mm}$ wide when spread out; lateral lobes obliquely triangular, erect; midlobe fleshy, widely ovatesubcordate, obtuse; disk with a ligulate, low callus. Column short, semiterete, to $2 \mathrm{~mm}$ long, produced at the base into a conspicuous foot. Pollinia 4, in two different sized pairs, on a short, dilated stipe. Anther cap cucullate, glabrous, 2-celled.

Distribution: A widespread and locally common species ranging from Guatemala to Panama in lowland wet forests.

Parque Nacional Manuel Antonio: Epiphytic on Cynometra hemitomophylla (guapinol negro) and other tall trees, mainly in primary and mature secondary forest. Plants are generally found on lower branches in medium shaded conditions. Occasional at PNMA.

Phenology: flowering mainly occurs from July to September.

3. Maxillaria oreocharis Schltr., Fedde Rep. Spec. Nov. Beih.: 17: 69. 1922.

Plant epiphytic, with scandent rhizome, erect or pendent, about $15 \mathrm{~cm}$ tall. Roots slender, flexuous, mainly produced from the rhizome under the basal pseudobulbs. Pseudobulbs elliptic to ovate-elliptic, complanate, green, to $3.2 \mathrm{~cm}$ long, $1.5-2 \mathrm{~cm}$ wide, covered with papyraceous sheaths, monophyllous. Leaves linear, acute to acuminate, contracted at the base into a very short petiole, to about $20 \mathrm{~cm}$ long, $0.8-1 \mathrm{~cm}$ wide. Inflorescence basal, from the axils of the upper sheaths, a single-flowered raceme to $3.5 \mathrm{~cm}$ long. Flowers spreading, white marked with red and the lip yellow with dark red lateral lobes. Sepals subsimilar, lanceolate to ovate-lanceolate, acute, concave toward the base, the lateral sepals adnate to the column foot to form a short mentum, 13-15 mm long, $5 \mathrm{~mm}$ wide. Petals lanceolate, acute, erect, $12 \mathrm{~mm}$ long, $3 \mathrm{~mm}$ wide. Lip 3-lobed, articulated with the column foot, oblong-ligular, the lateral lobes erect, rounded, the midlobe ovate, subacute, thickened, minutely puberulent $12 \mathrm{~mm}$ long, $5 \mathrm{~mm}$ wide across the lateral lobes; disc with a linear, fleshy callus. Column semiterete, curved, dilated at apex, the base produced into a foot, about $5 \mathrm{~mm}$ long. Amther cap cucullate, pubescent. Pollinia 4 on a saddleshaped stipe.

Distribution: A widespread but not common species in lowlands and middle elevation forests from Nicaragua to Panama.

Parque Nacional Manuel Antonio: The single collection from the protected area is from the low branches of a tree at the edge of primary forest, where the plants were growing in shaded conditions. Rare at PNMA.

Phenology: Flowering recorded in February to April.

\section{Maxillaria ponerantha Rchb.f.,} Bonplandia 2: 17. 1854. (Fig. 26).

Plant epiphytic, small, with ascending, freely branching stems, to $15 \mathrm{~cm}$ tall. Roots filiform, glabrous, produced only at the base of the main stem. Pseudobulbs elliptic to ovateelliptic, ancipitous, 1-2 cm apart, monophyllous, $1-1.3 \mathrm{~cm}$ long, about $0.8 \mathrm{~cm}$ wide, subtended by $2-4$ cataphylls, the leaves articulated with the sheaths and ultimately deciduous, the internodes enveloped in loosely imbricating, papery bracts. Leaves linearoblong, obtuse, unequally bilobed, $1.3-2.8 \mathrm{~cm}$ long, $0.4-0.8 \mathrm{~cm}$ wide. Inflorescences produced from the axil of cataphylls, 1flowered, single scapes about $5 \mathrm{~mm}$ long. Flowers small, very dark purple. Dorsal sepal ovate-lanceolate, subacute, concave, fleshy, 6$7 \mathrm{~mm}$ long, $2.8 \mathrm{~mm}$ wide. Lateral sepals elliptic-lanceolate, somewhat falcate, acute, dorsally carinate, free, $7 \mathrm{~mm}$ long, about $3 \mathrm{~mm}$ 

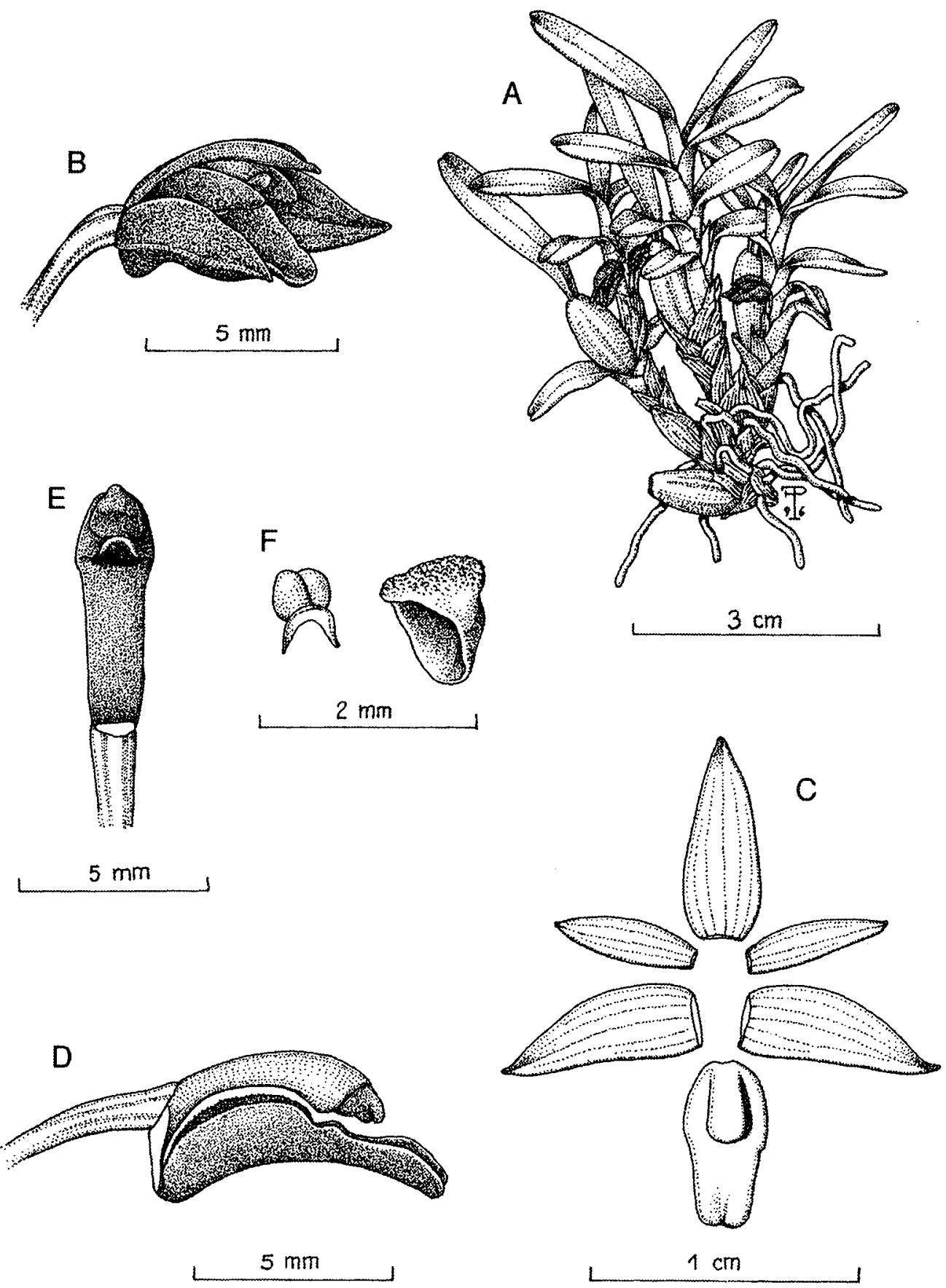

Fig. 26. Maxillaria ponerantha Rchb.f. A - Habit. B - Flower. C - Dissected perianth. D - Column and lip, lateral view. E - Column, ventral view. F - Pollinarium and operculum. Illustration voucher: F. Pupulin 345. 
wide. Petals elliptic-oblong, acute, $5 \mathrm{~mm}$ long, $1.3 \mathrm{~mm}$ wide. Lip narrowly ovate, obscurely 3-lobed, $6 \mathrm{~mm}$ long, $3 \mathrm{~mm}$ wide; lateral lobes elliptic, rounded, erect; midlobe fleshy, subquadrate, retuse; disk with a ligulate, fleshy callus. Column elongate, semiterete, $5 \mathrm{~mm}$ long, produced at the base into a short foot. Pollinia 4, in two different sized pairs, on a short, saddle-shaped stipe. Anther cap cucullate, verruculose, 1-celled.

Distribution: Widespread but not common from Costa Rica to northern South America.

Parque Nacional Manuel Antonio: Epiphytic on trunks and large branches of trees in primary and disturbed primary forest. Plants are only found on old trees with living bryophyte, in shaded conditions. Frequent at PNMA. The taxon is accepted here as $M$. ponerantha, but the consistent difference in color and minor morphological details in Costa Rican populations may perhaps deserve taxonomic recognition.

Phenology: flowering mainly occurs in July-August.

\section{NIDEMA Britt. \& Millsp.}

Cespitose, epiphytic, herbs with erect stems, with clustered pseudobulbs, 1-foliate at apex. Leaves conduplicate, linear, subcoriaceous, persistent. Inflorescence a fewflowered raceme from the apex of pseudobulbs. Flowers small. Sepals and petals free, not completely spreading, lanceolate elliptic; lip entire, articulated with the column base, smooth. Column arcuate, semiterete, with obscure wings. Pollinia 4 , in two pairs of different size.

A neotropical genus of some 2 species, widespread from Mexico to northern South America, and the West Indies.

1. Nidema ottonis (Rchb.f.) Britt. \& Millsp., Bahama Fl. 94. 1920. Epidendrum ottonis Rchb.f., Hamb. Gartenzeit. 14: 213. 1858. Nidema boothii var. triandrum Schltr. Fedde Rep. Sp. Nov. Beih. 17: 43. 1922. (Fig. 27).
Plant epiphytic, erect, with abbreviate rhizome, to $15 \mathrm{~cm}$ tall. Roots filiform, glabrous, produced at the base of pseudobulbs. Pseudobulbs ovate-pyriform, sometimes stalked, ancipitous, sulcate, monophyllous, $1.8-2.3 \mathrm{~cm}$ long, about $1 \mathrm{~cm}$ wide, subtended by 2-5 papyraceous sheaths. Leaves linear to oblong-lanceolate, unequally bilobed at apex, subcoriaceous, $7-12 \mathrm{~cm}$ long, $0.6-1 \mathrm{~cm}$ wide. Inflorescence terminal, often produced before the pseudobulb reachs maturity, a fewflowered raceme shorter than leaves, to 8-10 $\mathrm{cm}$ long including the peduncle, bearing 1-2 acute, spreading bracts. Flowers small, fragrant, creamy white, marked with yellow at the base of the lip. Sepals lanceolate, acute, somewhat concave towards the apex, $10 \mathrm{~mm}$ long, 2-2.5 mm wide; lateral sepals slightly falcate. Petals oblong-lanceolate, acute to acuminate, $8 \mathrm{~mm}$ long, $1.8 \mathrm{~mm}$ wide. Lip narrowly ovate-elliptic to linear, recurved near the base, $6.5 \mathrm{~mm}$ long, $1.8 \mathrm{~mm}$ wide, smooth. Column elongate, subclavate, arcuate, $4 \mathrm{~mm}$ long, contracted at the base. Pollinia 4, in two different sized pairs, on two short caudicles. Anther cap cucullate, carinate, 4-celled.

Distribution: A widespread species from southern Central America to Venezuela, Colombia, Peru, and the West Indies.

Parque Nacional Manuel Antonio: Plants of Nidema ottonis have been found in primary and secondary forest, epiphyte on branches and trunks in sunlighted spots, where they form large populations. The species is frequent at PNMA.

Phenology: Flowering mostly occurs from March to June.

\section{NOTYLIA Lindl.}

Cespitose, epiphytic herbs with clustered pseudobulbs, 1-foliate at apex, with or without conspicuous cataphylls. Leaves conduplicate, coriaceous, persistent. Inflorescence a pendent raceme from the axil of upper cataphylls, many-flowered. Flowers small. Sepals and petals spreading, the lateral sepals free to 

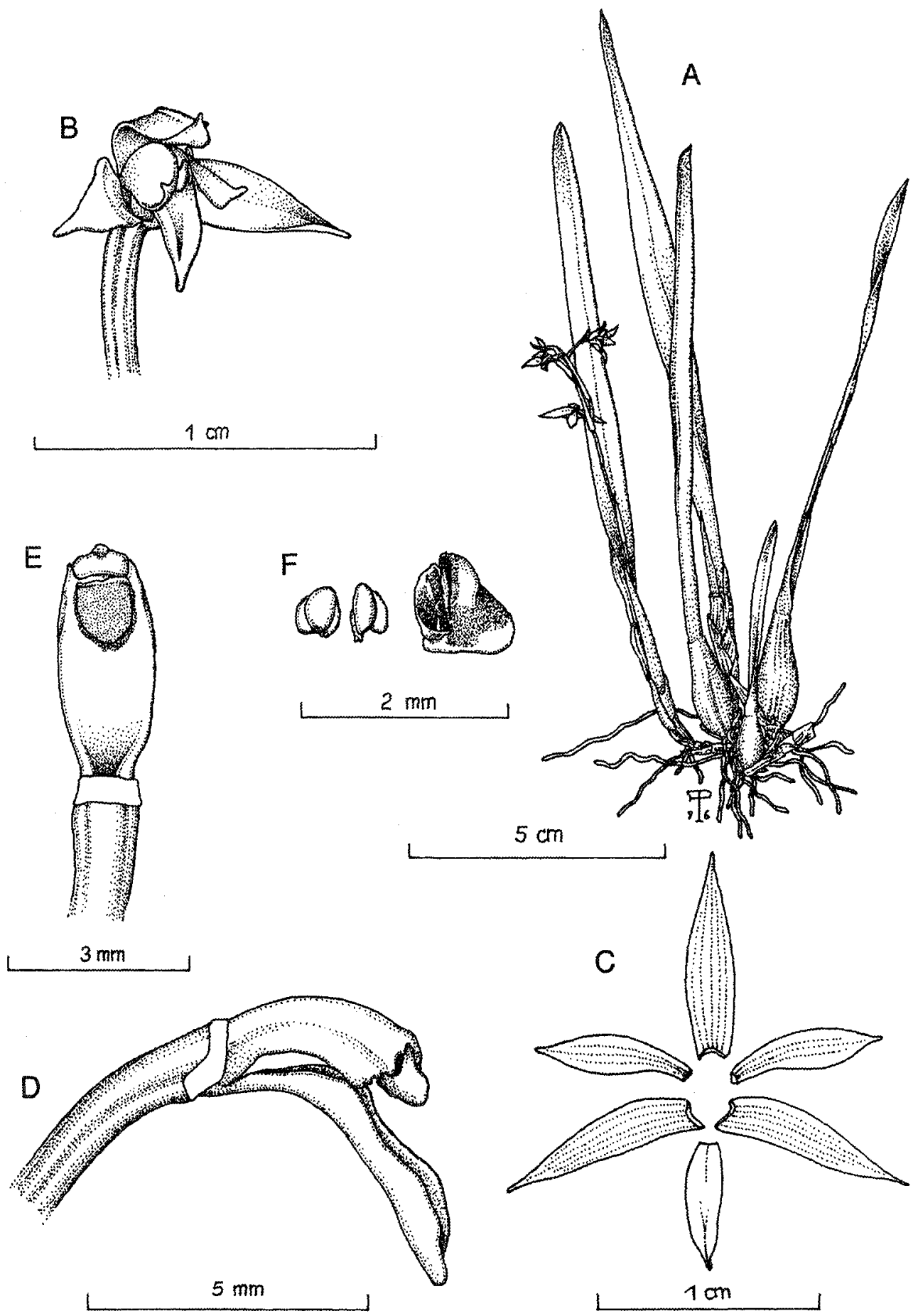

Fig. 27. Nidema ottonis (Rchb.f.) Britton \& Millsp. A - Habit. B - Flower. C - Dissected perianth. D - Column and lip, lateral view. E - Column, ventral view. F - Pollinaria and operculum. Illustration voucher: F. Pupulin 318. 
variously connate; lip clawed, entire or obscurely lobed, articulated with the column base, smooth or with a keeled callus. Column erect, semiterete, with dorsal anther. Pollinia 2, waxy.

A neotropical genus of some 45 species, widespread from Mexico to South America, and the West Indies.

1. Notylia pittieri Schltr., Beih. Bot. Centralbl. 36, Abt. 2: 502. 1918. (Fig. 28).

Plant epiphytic, pendent, to $20 \mathrm{~cm}$ tall, with very short rhizome. Roots fleshy, glabrous. Pseudobuibs clustered, ellipsoid, compress, $2.5 \mathrm{~cm}$ long, $0.7 \mathrm{~cm}$ wide, monophyllous, subtended by leafy and nonleafy scarious sheaths. Leaf coriaceous, abaxially finely rugulose, oblong-ligulate to elliptic, inequally bilobed at apex, obscurely mucronate, to $10.2 \mathrm{~cm}$ long, $3.9 \mathrm{~cm}$ wide. Inflorescence basal, emerging from the axil of imbricating leaf base, pendent, racemose or secundarily paniculate, to $19 \mathrm{~cm}$ long, manyflowered (to 80 and more); bracts small, triangular-lanceolate, acuminate, $2 \mathrm{~mm}$ long. Flowers small, with greenish white sepals, white petals with 3 yellow blotches, and white lip. Dorsal sepal oblong-ligulate, obtuse, slightly acuminate, deeply revolute, concave, $4.8 \mathrm{~mm}$ long, $1.5 \mathrm{~mm}$ wide. Lateral sepals connate just to $1 \mathrm{~mm}$ from apex, broadly oblong to obovate, the apex obtuse, reflexed, $4.1 \mathrm{~mm}$ long, $2 \mathrm{~mm}$ wide. Petals obliquely ligulate-subfalcate, acute, $4.2 \mathrm{~mm}$ long, 1.2 $\mathrm{mm}$ wide. Lip shortly clawed; lamina triangular-subhastate, subobtuse, dorsally carinate at apex, with a basal thickened, linearoblong callus produced by the extension of the thick claw, $3.4 \mathrm{~mm}$ long, $1.9 \mathrm{~mm}$ wide. Column terete, slender, with dorsal anther, 2.5 $\mathrm{mm}$ long. Pollinia 2, obtriangular, laterally flattened, on a long, obtriangular attenuate stipe; viscidium elliptic, brown. Anther cap oblong, cucullate, $1.4 \mathrm{~mm}$ long.

Distribution: Endemic to Costa Rica.

Parque Nacional Manuel Antonio: Plants were found as epiphyte on Citrus sp. (limón) and Cynometra hemitomophylla (guapinol negro) in young secondary forest and in shaded conditions. Notylia pittieri is probably pollinated by bees of the genus Euglossa. The species is occasional at PNMA.

Phenology: flowering recorded in JulyAugust.

\section{ONCIDIUM $\mathrm{Sw}$.}

Cespitose to scandent, epiphytic, rarely terrestrial herbs with foliaceous stem frequently thickened into definite pseudobulbs, 1- to 2-foliate (rarely more) at apex, with or without conspicuous cataphylls. Leaves conduplicate or terete, subcoriaceous to fleshy, persistent. Inflorescence a often flexuous, erect to pendent raceme, frequently paniculate, from the lateral bases of pseudobulbs, usually many-flowered. Flowers usually large and conspicuous, often yellow and brown. Sepals and petals usually spreading, the lateral sepals free to variously connate; lip clawed, usually 3-lobed, often pandurate, the disc usually cristate or tuberculate. Column erect, semiterete, often winged, provided at the base with a tabula infrastigmatica, with terminal anther. Pollinia 2 , usually deeply sulcate, waxy.

A polimorphic genus of some 400 species, widespread in the Neotropics from Florida to the West Indies and to Bolivia, Brazil and Argentina in South America.

1. Oncidium ascendens Lindl., Bot. Reg. 28: sub. t. 4. 1842. Oncidium helicanthum Krzl. in Engler, Pflanzenr. 4. 50, Heft. 80: 95. 1922. Oncidium subulifolium Schltr., Fedde Rep. Sp. Nov. 10: 79. 1922. (Fig. 29).

Plant epiphytic, pendent, to $70 \mathrm{~cm}$ tall, with very short rhizome. Roots fleshy, glabrous, branched. Pseudobulbs clustered, inconspicuous, rounded, to $1 \mathrm{~cm}$ long, $0.8 \mathrm{~cm}$ wide, monophyllous, subtended by papyraceous sheaths. Leaf fleshy, terete, attenuate toward the apex, adaxially canaliculate, to $70 \mathrm{~cm}$ long, $1.6 \mathrm{~cm}$ wide. Inflorescence lateral, emerging from the axil of the imbricating sheaths, paniculate, pendent, 
E

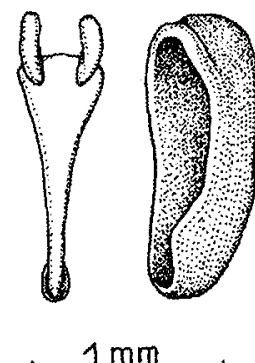

B

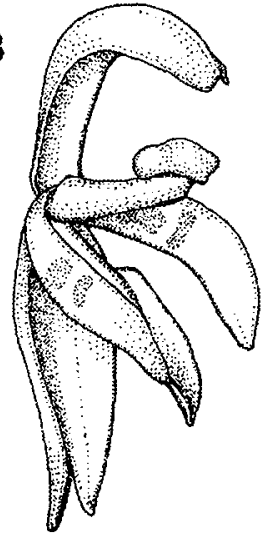

$5 \mathrm{~mm}$

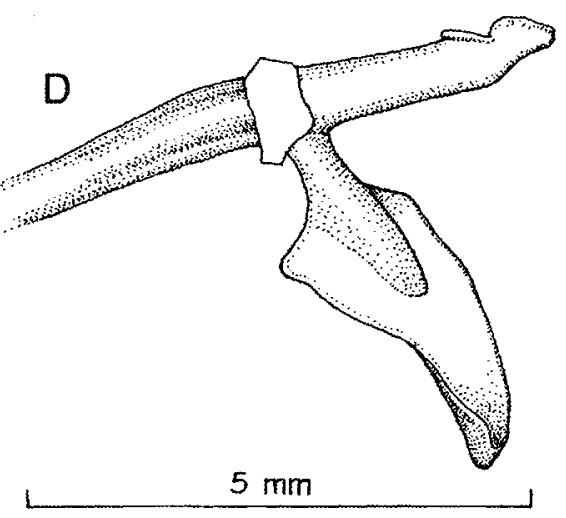

A
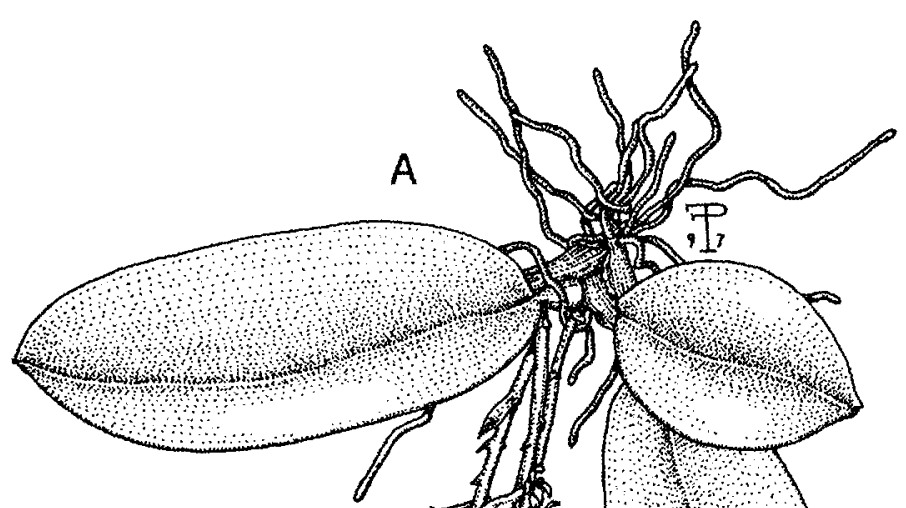

$5 \mathrm{~cm}$ 

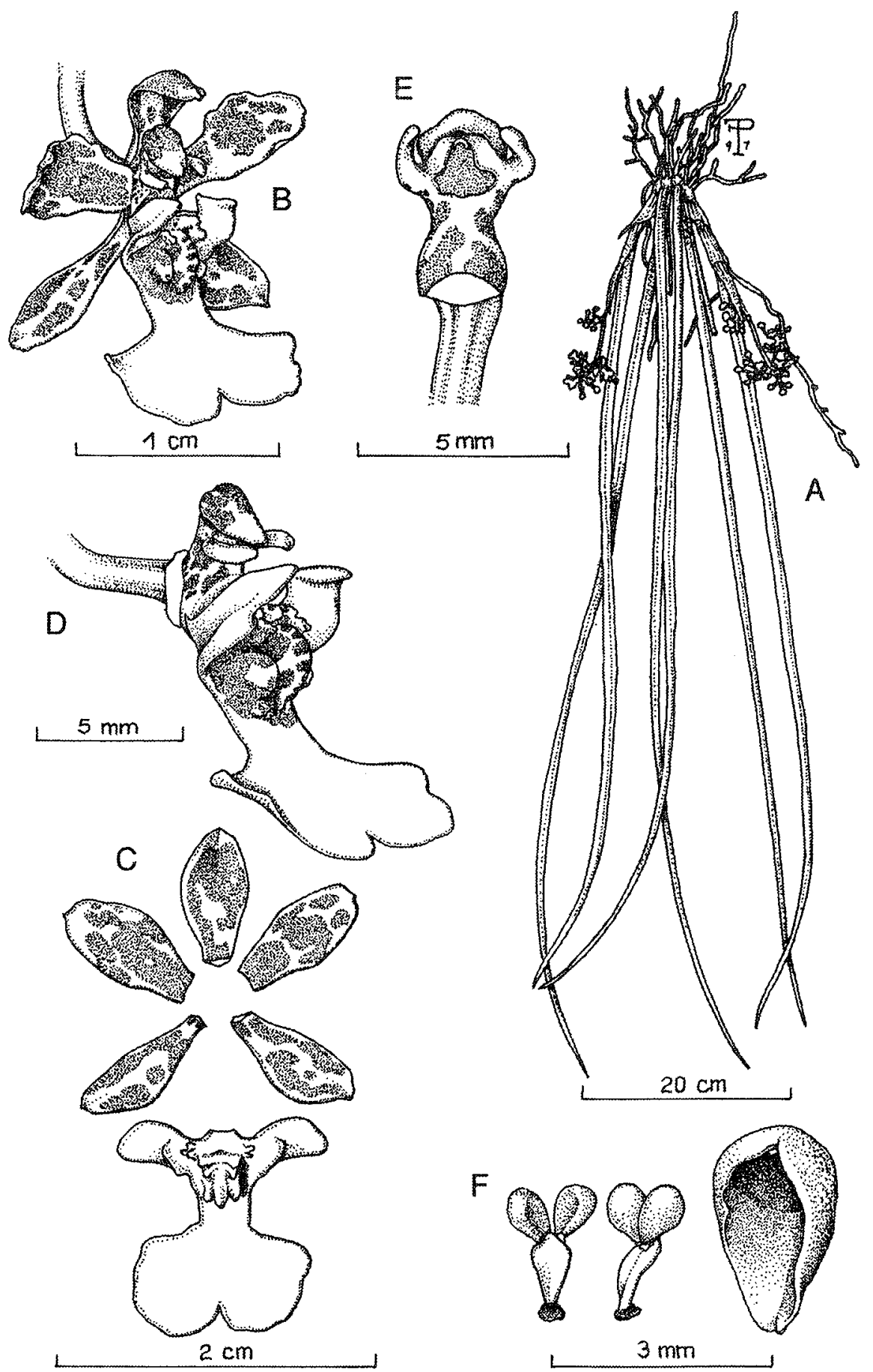

Fig. 29. Oncidium ascendens Lindl. A - Habit. B - Flower. C - Dissected perianth. D - Column and lip, lateral view. E Column, ventral view. F - Pollinarium and operculum. Illustration voucher: F. Pupulin 322. 
becaming erect when mature, to $20 \mathrm{~cm}$ long, many-flowered. Flowers small, with sepals and petals yellow blotched with reddish-brown and the lip yellow, spotted with brown on the callus. Dorsal sepal elliptic-oblong, obtuse, deeply concave, $8 \mathrm{~mm}$ long, $4 \mathrm{~mm}$ wide. Lateral sepals obliquely oblong, the apex obtuse, minutely apiculate, $9 \mathrm{~mm}$ long, $4 \mathrm{~mm}$ wide. Petals elliptic-obovate, obtuse, apiculate, $9 \mathrm{~mm}$ long, $6 \mathrm{~mm}$ wide. Lip 3lobed; the lateral lobes subquadrate elliptic, truncate, erect, with two thickened calli at the base; midlobe flabellate, with a distinct isthmus, the lamina deeply emarginate to bilobed at apex; disc with a complex callus formed by a central, rounded keel surrounded by many short to long, acicular projections; entire lip $1.3 \mathrm{~cm}$ long, $1.3 \mathrm{~cm}$ wide between the lateral lobes. Column short, stout, provided with two elongate, incurved, stigmatic arms, $3.5 \mathrm{~mm}$ long. Pollinia 2 , pyriform, sulcate, on a narrow, rhombic stipe; viscidium elliptic, brown. Anther cap obovate-oblong, cucullate, $2.6 \mathrm{~mm}$ long.

Distribution: Epiphytic in lowland, disturbed forests from Mexico to Costa Rica, and the West Indies.

Parque Nacional Manuel Antonio: A single plant was found growing on the trunk of a short tree in secondary, very disturbed forest. The species is rare at PNMA. May.

Phenology: flowering occurs in April-

2. Oncidium polycladium Rchb.f. ex Lindl., Fol. Orch. Oncidium, 47. 1855.

Plant epiphytic, to $70 \mathrm{~cm}$ tall, with short and stout rhizome. Roots fleshy, glabrous. Pseudobulbs clustered, ovate-elliptic, laterally compressed, sometimes slightly curved, strongly grooved during dry season, to $13 \mathrm{~cm}$ long, $4 \mathrm{~cm}$ wide, diphyllous, subtended by large, scarious sheaths, with leafy limb. Leaves subcoriaceous, erect, linear, acute, canaliculate toward the base, to $35 \mathrm{~cm}$ long, $2.5 \mathrm{~cm}$ wide. Inflorescence lateral, erect, emerging from the axil of the leafy sheaths, racemose to paniculate with short branchlets, to $1 \mathrm{~m}$ long, many-flowered. Flowers yellow, with sepals and petals striped and blotched with reddish-brown; the lip with a large brown blotch at the base of the midlobe. Dorsal sepal short unguiculate, elliptic, acuminate, with undulate margins, $13 \mathrm{~mm}$ long, $5 \mathrm{~mm}$ wide. Lateral sepals obliquely lanceolate, acute, 17 $\mathrm{mm}$ long, $4.3 \mathrm{~mm}$ wide. Petals ellipticobovate, acute to acuminate, $13 \mathrm{~mm}$ long, 4 $\mathrm{mm}$ wide. Lip 3-lobed, widely pandurate; the lateral lobes rounded; the midlobe without a distinct isthmus, the lamina reniform, retuse to emarginate at apex; disc with a callus composed by two diverging ears at the base and a central keel surrounded by two acicular projections at the middle and two apical teeth; entire lip $15 \mathrm{~mm}$ long, $17 \mathrm{~mm}$ wide across the midlobe. Column slender, provided with two narrowly triangular, crenulate wings, $4.5 \mathrm{~mm}$ long. Pollinia 2, pyriform, sulcate, on a narrow stipe; viscidium elliptic, brown. Anther cap cucullate.

Distribution: Epiphytic in lowland forests from Mexico to Costa Rica.

Parque Nacional Manuel Antonio: A single collection was done not far from the northern borders of the park, where the plant was found growing on young trees in secondary disturbed forest. This taxon is part of a complex of closely allied species with very similar morphology, including $O$. baueri, $O$. isthmi, $O$. panamense, $O$. sphacelatum, and $O$. stenotis. I accept here this species as $O$. polycladium on the basis of the lack of a distinct isthmus on the lip. The species should be considered rare at PNMA.

Phenology: flowering mainly occurs in April.

3. Oncidium stenobulbon Krzl. in Engler, Pflanzenr. 4. 50, Heft. 80: 281. 1922. (Fig. 30).

Plant epiphytic, cespitose, to $20 \mathrm{~cm}$ tall. Roots fleshy, glabrous. Pseudobulbs clustered, ovate-elliptic, laterally strongly flattened, smooth, sometimes slightly curved, with sharp edges, to $10 \mathrm{~cm}$ long, $7 \mathrm{~cm}$ wide, diphyllous, subtended by large, foliaceous 


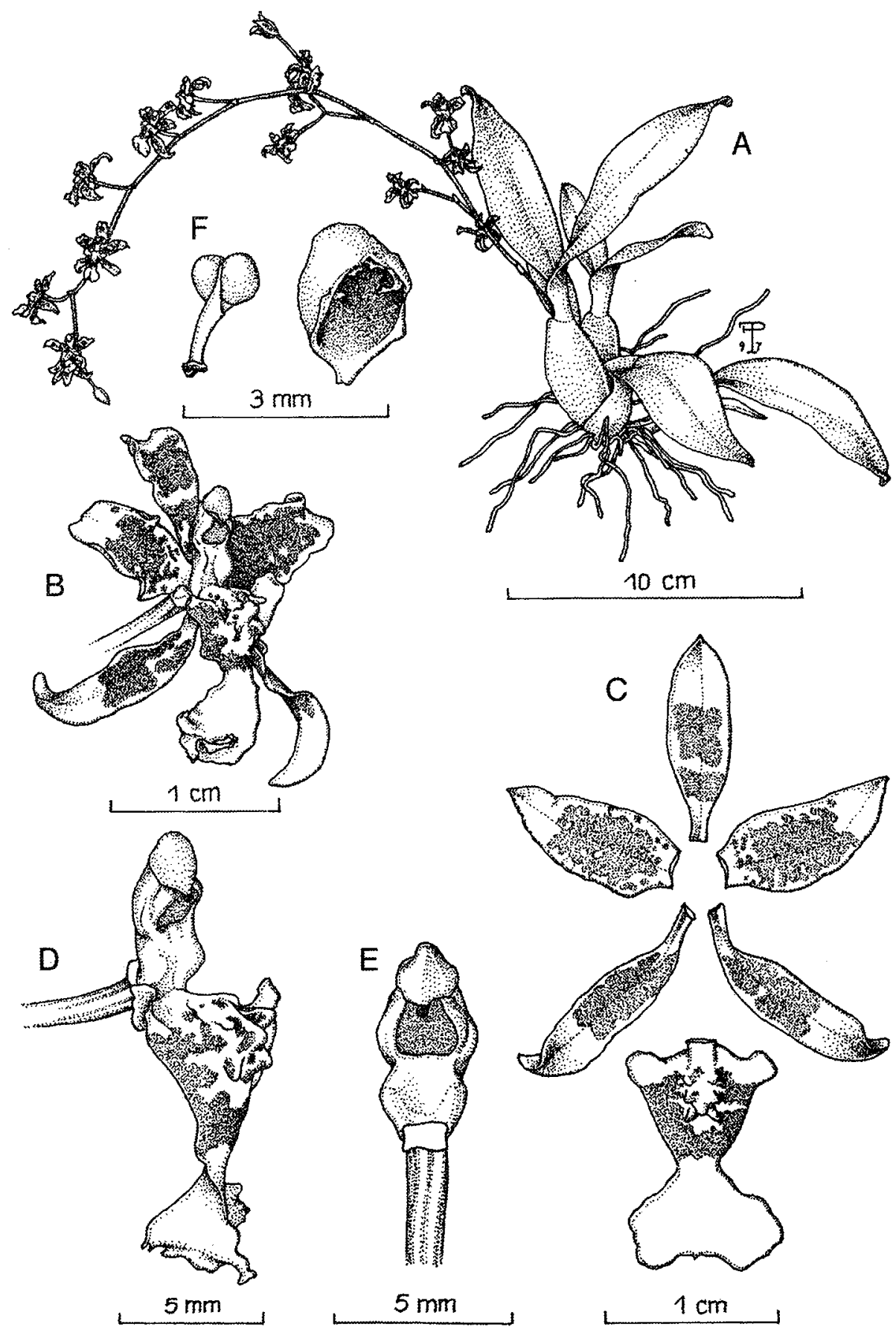

Fig. 30. Oncidium stenobulbon Krzl. A - Habit. B - Flower. C - Dissected perianth. D - Column and lip, lateral view. E Column, ventral view. F - Pollinarium and operculum. Illustration voucher: F. Pupulin 303. 
sheaths. Leaves thin, erect, elliptic to narrowly elliptic, acute, canaliculate toward the base, to $10 \mathrm{~cm}$ long, $4 \mathrm{~cm}$ wide. Inflorescence lateral, erect, emerging from the axil of the leafy sheaths, racemose to paniculate with short branchlets, to $40 \mathrm{~m}$ long, many-flowered. Flowers yellow, with sepals and petals striped and blotched with reddish-brown; the lip with a large brown blotch on the isthmus. Dorsal sepal unguiculate, elliptic, acute, with undulate margins, $15 \mathrm{~mm}$ long, $4.5 \mathrm{~mm}$ wide. Lateral sepals shortly unguiculate, obliquely lanceolate to ligulate, acute, $18 \mathrm{~mm}$ long, 4 $\mathrm{mm}$ wide. Petals ovate to lanceolate, acute, 13 $\mathrm{mm}$ long, $6 \mathrm{~mm}$ wide. Lip 3-lobed, with short lateral lobes, rounded to subquadrate at apex; the isthmus triangular, abruptly constricted toward the insertion of the midlobe; midlobe obcordate, emarginate, with a short apicule; disc with a callus composed by a central keel surrounded by 4 basal projections and two apical teeth; entire lip $17 \mathrm{~mm}$ long, $11 \mathrm{~mm}$ wide across the midlobe. Column stout, provided with two obscure wing-like keels, $4 \mathrm{~mm}$ long. Pollinia 2, suborbicular, sulcate, on a narrow stipe with a dorsal projection; viscidium elliptic, brown. Anther cap cucullate.

Distribution: Endemic to Costa Rican lowlands.

Parque Nacional Manuel Antonio: Plants of Oncidium stenobulbon have not yet been observed within PNMA area. The single collection is from the low hills north of the park, where the plants were found on the main trunks of large trees in remnant of primary forest. The species should be considered rare at PNMA.

Phenology: flowering mainly occurs in January to March.

\section{PLEUROTHALLIS R. Br.}

Cespitose or creeping herbs with monophyllous ramicauls at least partly concealed by unadorned sheaths. Inflorescence a terminal raceme. Sepals subequal, free or variously connate; petals generally smaller than sepals; lip simple or 3-lobed. Column with a foot at the base. Pollinia 2.

A neotropical genus of about 1,500 species.

1. Pleurothallis corniculata (Sw.) Lindl., Bot. Reg. 28: Misc. 83, 1842. Epidendrum corniculatum Sw., Prodr. 123, 1788. Pleurothallis nubigena Lindl. Ann. \& Mag. Nat. Hist. 3: 326, 1858. Pleurothallis jocolensis Ames, Sched. Orch. 2: 19, 1923. (Fig. 31).

Plant small, cespitose, to $6 \mathrm{~cm}$ tall, with abbreviated rhizome. Roots filiform, glabrous. Ramicauls abbreviated, to about $1.1 \mathrm{~cm}$ long, monophyllous, covered by 3 tubular, scarious sheaths. Leaf obovate to oblong-elliptic, coriaceous, with a short, sulcate petiole, emarginate and obscurely tridenticulate at apex, to $4.6 \mathrm{~cm}$ long, $0.8-1 \mathrm{~cm}$ wide. Inflorescence erect, filiform, emerging from the insertion of the leaf, 1-flowered, subequal to the leaf, to $5.5 \mathrm{~cm}$ long, provided with a small, scarious, acuminate bract toward the base, $2.5 \mathrm{~mm}$ long. Flowers small, orange. Dorsal sepal oblong-lanceolate, narrowly obtuse, verruculose at apex, $7.2 \mathrm{~mm}$ long, 2.5 $\mathrm{mm}$ wide. Lateral sepals connate almost to the apex to form a obovate-elliptic lamina, obtuse and emarginate at apex, $6.3 \mathrm{~mm}$ long, $3.2 \mathrm{~mm}$ wide. Petals obliquely oblong, falcate at the base, acute, glandulose, thickened at apex, $2.5 \mathrm{~mm}$ long, $1.1 \mathrm{~mm}$ wide at the middle. Lip linear-elliptic, truncate, with two small retrorse lobules at the base, provided at apex with two clumps of short hairs along the margins, the disc with a central groove at the base, laterally finely papillose, $2.6 \mathrm{~mm}$ long, $0.8 \mathrm{~mm}$ wide. Column with a conspicuous foot at the base, linear, winged, tridenticulate at apex, $1.8 \mathrm{~mm}$ long. Pollinia 2, narrowly obtriangular, laterally flattened. Anther cap subtriangular, cucullate, 2-celled, $0.4 \mathrm{~mm}$ long.

Distribution: Epiphytic in dense tropical forests in West Indies, Mexico, Guatemala, Honduras, Nicaragua, Costa Rica, and Guyana (?). 


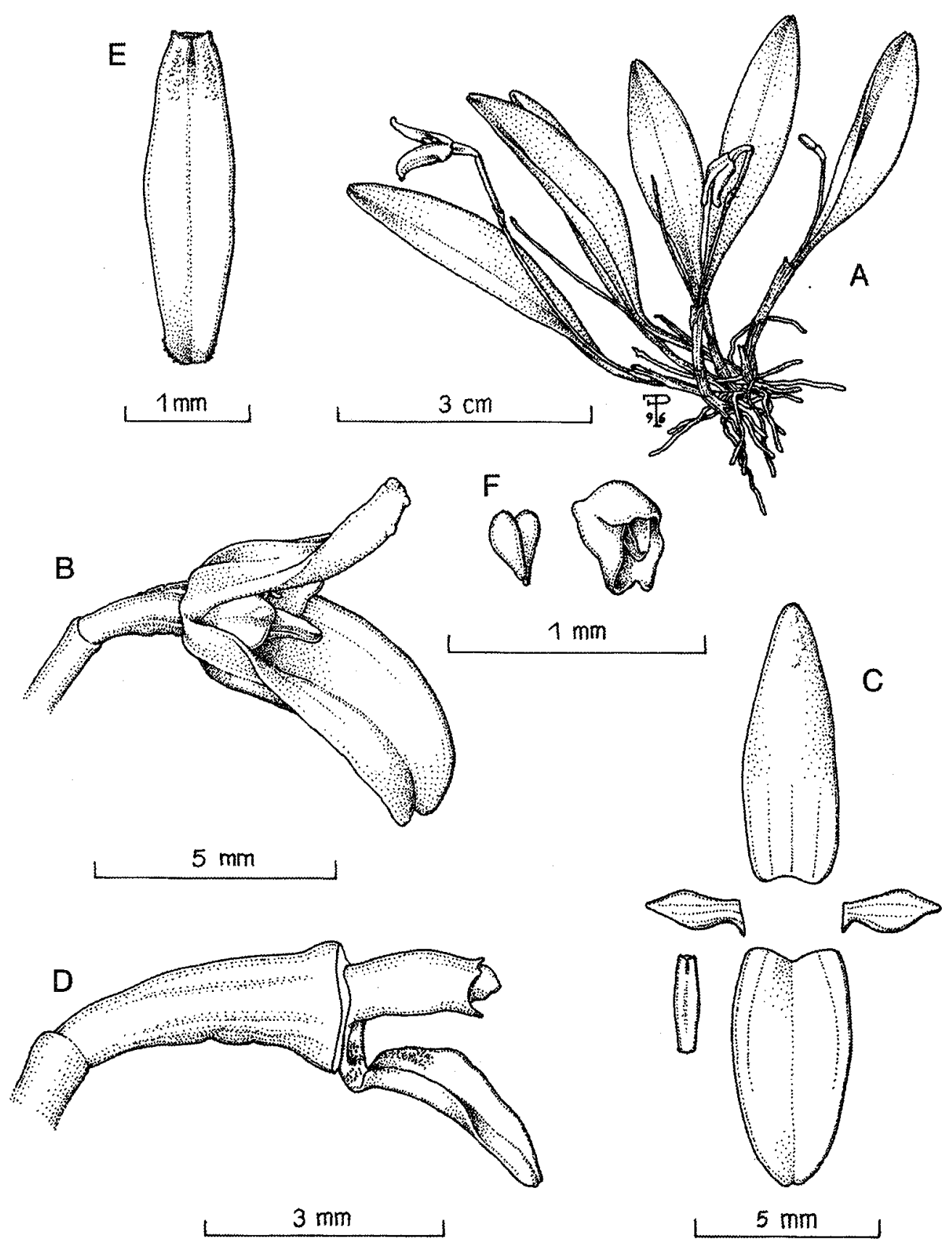

Fig. 31. Pleurothallis corniculata (Sw.) Lindl. A - Habit. B - Flower. C - Dissected perianth. D - Column and lip, lateral view. E - Lip. F - Pollinarium and operculum. Illustration voucher: F. Pupulin 295. 
Parque Nacional Manuel Antonio: Plants were found as epiphyte on western or northwestern faces of large trunks of Brosimum utile trees in primary forest and mature secondary forest. The species is frequent at PNMA.

Phenology: flowering begins in September through December and January.

2. Pleurothallis lewisae Ames, Proc. Biol. Soc. Wash. 44: 41, 1931. (Fig. 32).

Plant minute, to $7 \mathrm{~cm}$ tall, with creeping rhizome. Roots filiform, glabrous. Ramicauls very abbreviated, 1-3 mm long, monophyllous, covered by 2 tubular sheaths. Leaf obovate to broadly elliptic, coriaceous, abaxially finely rugulose, emarginate at apex, to $0.5-1.1 \mathrm{~mm}$ long, $3.9-7 \mathrm{~mm}$ wide. Inflorescence erect, emerging from the base of the leaf, consecutively 1 - to 2-flowered, to 1.2 $\mathrm{mm}$ long, with a small, triangular-lanceolate, acuminate bract, $0.8 \mathrm{~mm}$ long. Flowers small, reddish-brown. Dorsal sepal oblong, blunty acute, 5-6 mm long, 2.5-3 mm wide. Lateral sepals slightly connate at the base, lanceolate-oblong, acute, 5-6 mm long, 1.8-2.5 mm wide. Petals oblong, obscurely apiculate, glandulose, with minutely dentate margins, $4-5 \mathrm{~mm}$ long, $2.5 \mathrm{~mm}$ wide. Lip oblong-elliptic, with two triangular lobes below the middle, minutely glandulose, the disc slightly tickened and verrucose, $2.5 \mathrm{~mm}$ long, 1.1 $\mathrm{mm}$ wide between the lobes. Column with a short foot at the base, arcuate, winged, irregularly dentate at apex, $2.5 \mathrm{~mm}$ long. Pollinia 2, narrowly obtriangular, laterally flattened. Anther cap hemiglobose, cucullate, $0.4 \mathrm{~mm}$ long.

Distribution: A rather inconspicuous Central American species, ranging from Guatemala to Panama in lowland rain forests.

Parque Nacional Manuel Antonio: Plants were found as epiphyte, closely appressed to the bark of large branches and limbs of Cynometra hemitomophylla (guapinol negro) trees in primary forest, in very shaded conditions. The species has been found only within a single plot and should therefore be considered rare at PNMA. However, it is probable his very small size renders it easily overlooked.

Phenology: flowering occurs from August through December.

\section{POLYSTACHYA Hook.}

Cespitose, epiphytic, rarely terrestrial herbs, usually provided with definite pseudobulbs. Leaves 1-2, conduplicate, coriaceous, persistent. Inflorescence a raceme, often paniculate, from the apex of pseudobulbs, many-flowered. Flowers small, non-resupinate. Lateral sepals larger than dorsal sepal, variously connate to form a mentum; petals smaller than sepals, spreading; lip shortly clawed, entire or 3-lobed, smooth or with a conspicuous callus, often covered with farinaceous cells. Column erect, semiterete, with a prominent foot and terminal anther. Pollinia 4, waxy, sometimes joined into 2.

A pantropical genus of some 200 species, mainly African and Asian in distribution.

1. Polystachya foliosa (Lindl.) Rchb.f., Ann. Bot. Syst. t. 6: 640. 1863. Stelis foliosa Lindl., Ann. Mag. Nat. Hist. 2: 330, t. 17. 1839. Polystachya cerea Lindl., Edward's Bot. Reg. 26: Misc. p. 86. 1840. Polystachya clavata Lindl., Edward's Bot. Reg. 20: Misc. p. 61. 1842. Polystachya weigeltii Rchb. f. Linnaea 25: $230.1852 . \quad$ Polystachya caracasana Rchb. f., Bonplandia 2: 15. 1854 Dendrorchis caracasana (Rchb.f.) O. Ktze., Rev. Gen. Pl. 659. 1891. Polystachya minor Fawc. \& Rendle, J. Bot. 48: 106. 1910. Polystachya altilamellata Schltr., Repert. Spec. Nov. Regni Veg. 10: 385. 1912. Polystachya ecuadorensis Schltr., Repert. Spec. Nov. Regni Veg. Beih. 8:90. 1921. Polystachya poeppigii Schltr., Repert. Spec. Nov. Regni Veg. Beih. 9: 155. 1921. Polystachya guatemaltensis Schltr., Repert. Spec. Nov. Regni Veg. Beih. 17: 141. 1921. Polystachya panamensis Schltr., Repert. Spec. Nov. Regni Veg. Beih. 17: 49. 1922. Polystachya costaricensis Schltr., Repert. Spec. Nov. Regni Veg. Beih. 19: 223. 1923. Polystachya cubensis Schltr., Urb. Sym. Ant. 9: 59. 1923. Polystachya powellii Ames, Sched. Orch. 7: 31. 1924. Polystachya huebneri Schltr., Beih. Bot. Centralbl. 43, 2: 112. 1925. (Fig. 33). 

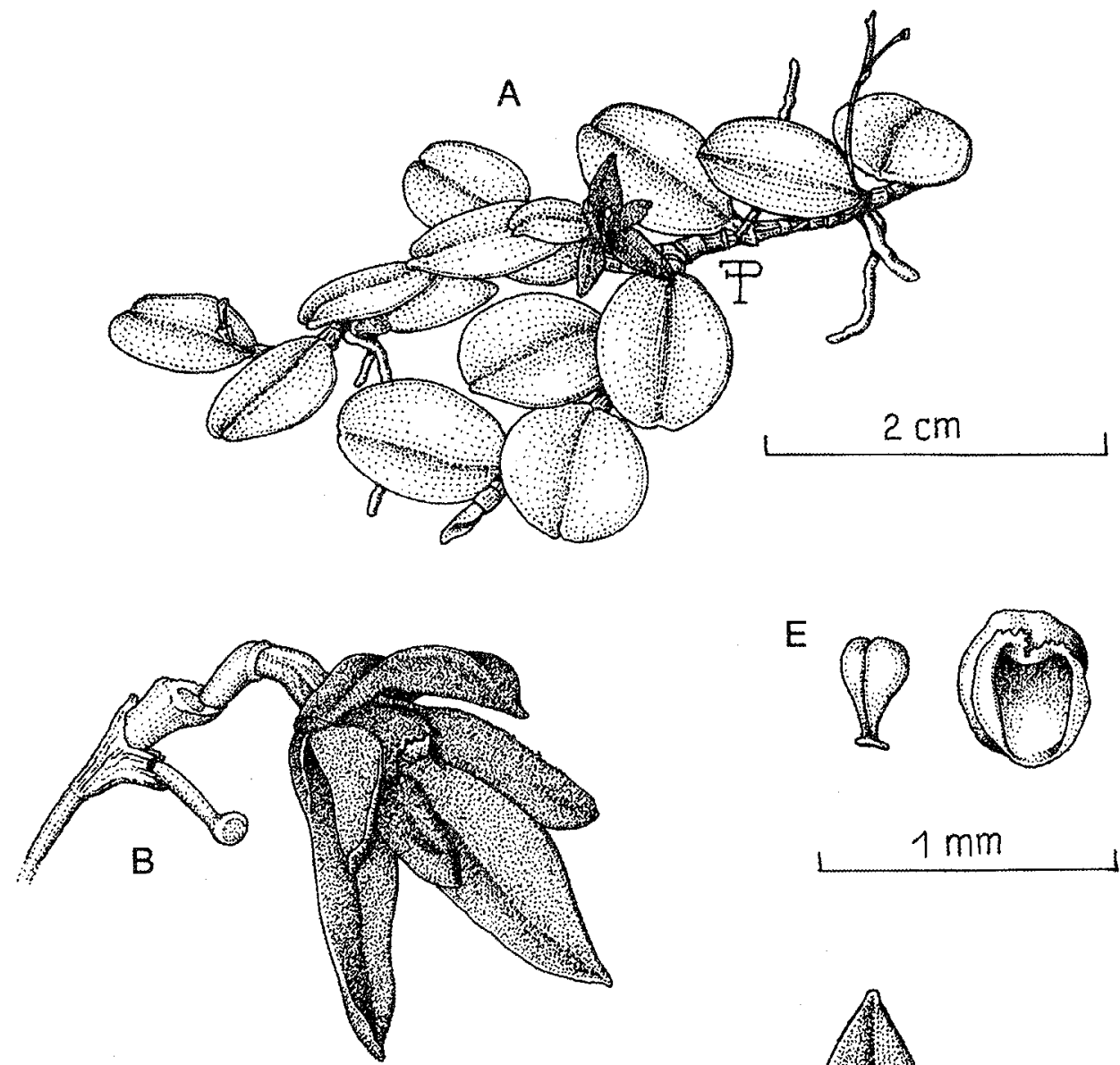

E
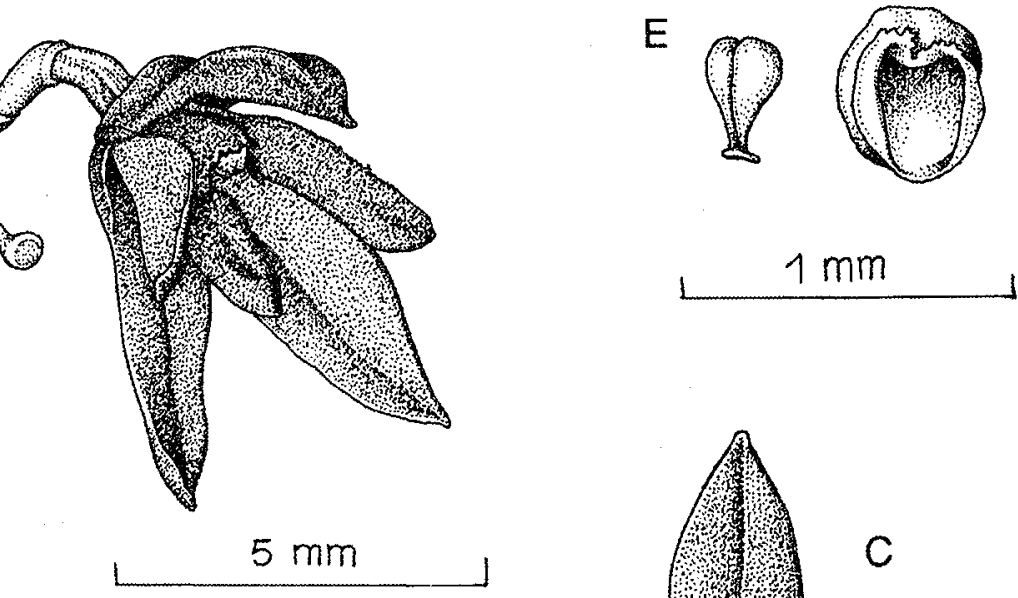

C
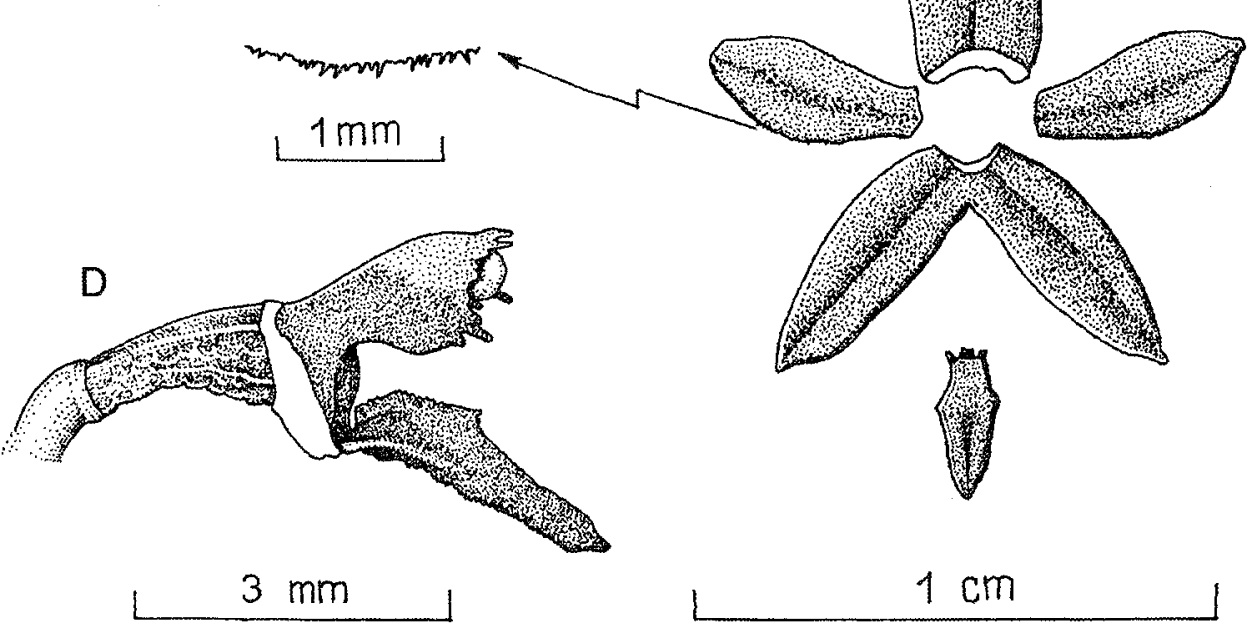

$1 \mathrm{~cm}$

Fig. 32. Pleurothallis lewisae Ames. A - Habit. B - Flower. C - Dissected perianth. D - Column and lip, lateral view. E Pollinarium and operculum. Illustration voucher: F. Pupulin 360. 

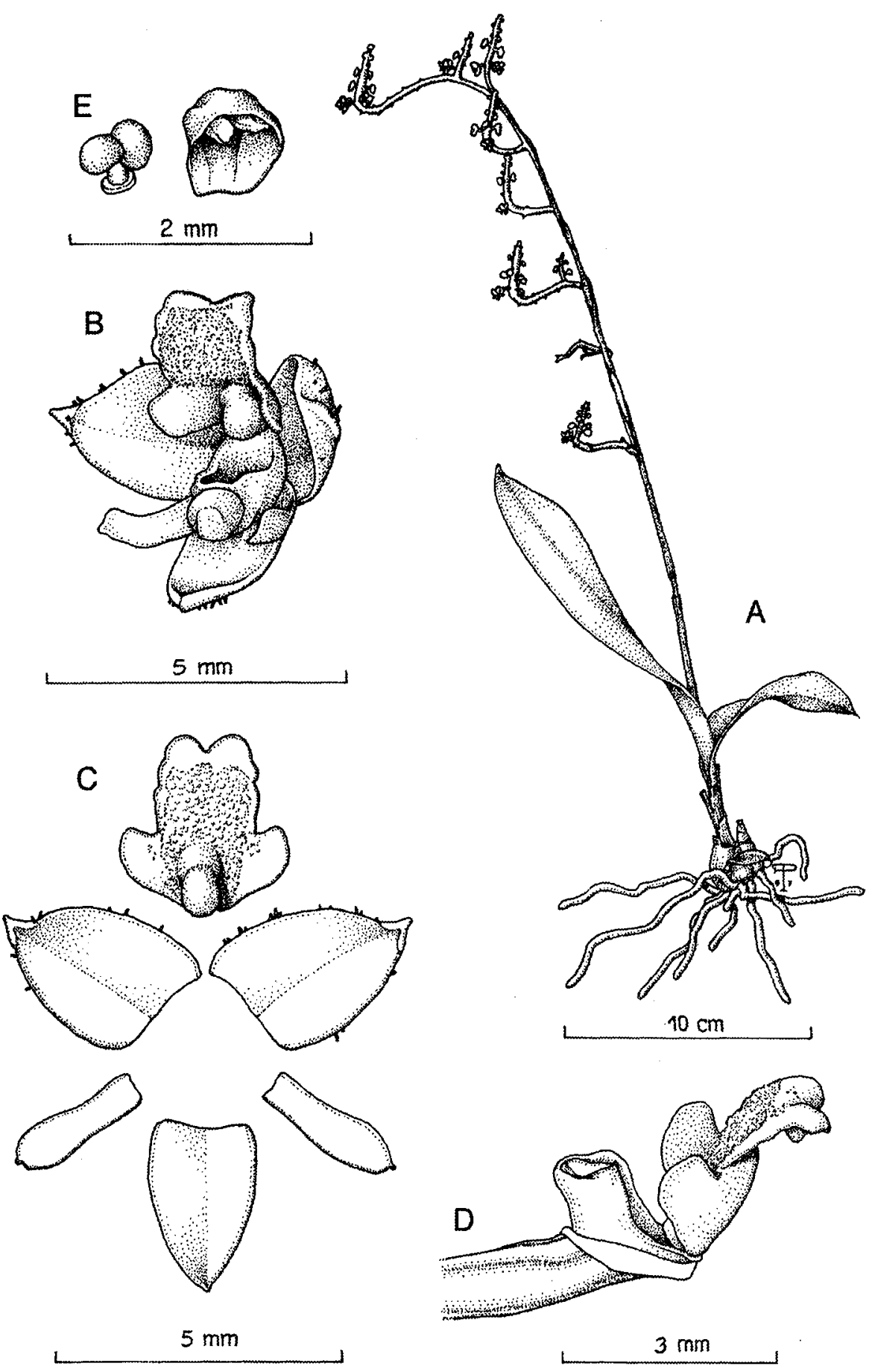

Fig. 33. Polystachya foliosa (Lind1.) Rchb.f. A - Habit. B - Flower. C - Dissected perianth. D - Column and lip, lateral view. E - Pollinarium and operculum. Illustration voucher: F. Pupulin 468. 
Plant epiphytic, cespitose, erect, to about $20 \mathrm{~cm}$ tall, with short, pseudobulbous stems. Roots fleshy, glabrous. Pseudobulbs ovoid to fusiform, enclosed in basal, papyraceous sheaths when young, to $3 \mathrm{~cm}$ long, $1.6-2 \mathrm{~cm}$ wide, bearing 3-5 leaves. Leaves oblongelliptic, to oblanceolate, subcoriaceous, articulate to the sheaths envolving the stem at the base, to $20 \mathrm{~cm}$ long, $1.3-3 \mathrm{~cm}$ wide. Inflorescence terminal, a single, manyflowered raceme or usually with several short branches from the nodes of the peduncle; peduncle covered with long, acuminate, imbricating scarious bracts; the rhachis fuzzypubescent. Ovaries sessile, finely pubescent. Flowers small, with yellowish to pale orange sepals and petals, the lip with a white callus and whitish verrucules. Dorsal sepal ovate, concave, acute, dorsally sparsely pubescent, $3.5 \mathrm{~mm}$ long, $2 \mathrm{~mm}$ wide. Lateral sepals obliquely broadly ovate, acute, pubescent, 4 $\mathrm{mm}$ long, $3 \mathrm{~mm}$ wide. Petals falcate-oblong, obtuse to acute at apex, $2.5 \mathrm{~mm}$ long, $1 \mathrm{~mm}$ wide. Lip 3-lobed, oblong-ovate; lateral lobes small, rounded, acute at apex; the midlobe suborbicular, truncate, retuse, farinose on the inner surface; disc provided with a mamillate callus at the base; entire lip $3.5 \mathrm{~mm}$ long, $3 \mathrm{~mm}$ wide. Column stout, with a short foot, about 1 mm long. Pollinia 4, on a short caudicle. Anther cap cucullate, somehath triangular, 2 celled.

Distribution: A widespread species in the Neotropic, distributed from Mexico to South America and the West Indies.

Parque Nacional Manuel Antonio: Plants of Polystachya foliosa are locally common in secondary vegetation along the eastern border of the park. However, it has not yet been reported from PNMA, where it is regarded as rare.

Phenology: flowering occurs in September and October.

20. SCAPHYGLOTTIS Poepp. \& Endl.

Cespitose or repent, epiphytic herbs, with definite pseudobulbs or thickened, simply or fasciculated, branched stems. Leaves 1-3, conduplicate to semiterete, thin to coriaceous, persistent. Inflorescence a terminal fascicle or a raceme, 1- to few-flowered. Flowers usually small. Sepals and petals subequal, spreading; lip articulated with the column foot, straight to geniculate, with or without a claw, entire or 3lobed. Column short, usually with a short to prominent foot, provided with wings or auricles or wingless, the anther terminal, incumbent. Pollinia 4 or 6, lateraaly compressed, ceraceous.

A neotropical genus of some 50 species, distributed from Mexico to Brazil and Bolivia, and the West Indies.

1. Scaphyglottis micrantha (Lindl.) Ames \& Correll, Bot. Mus. Leafl. Harv. Univ. 10: 85, 1942. Hexadesmia micrantha Lindl., Bot. Reg. 30: Misc. 2, 1844. (Fig. 34).

Plant epiphytic, cespitose, ascending, to about $16 \mathrm{~cm}$ tall, with abbreviated rhizome. Roots filiform, slender, glabrous, with green vegetative apex. Pseudobulbs fusiform, stipitate, somewhat curved, unbranched, diphyllous, subtended by many scarious, imbricating sheaths, to $7 \mathrm{~cm}$ long, $0.8 \mathrm{~cm}$ wide. Leaves linear, obliquely retuse, to $8.4 \mathrm{~cm}$ long, $0.8 \mathrm{~cm}$ wide. Inflorescence terminal, racemose, many-flowered, to $8.5 \mathrm{~cm}$ long; peduncle filiform, provided with several, spreading sheaths, subtended by several scarious sheaths. Ovaries pedicellate, linear, abruptly thickened at apex. Flowers very small, with white sepals and petals, and green lip and column. Dorsal sepal elliptic-obovate, obtuse to slightly apiculate, concave, $2 \mathrm{~mm}$ long, $1 \mathrm{~mm}$ wide. Lateral sepals obliquely broadly ovate-elliptic, apiculate, $1.9 \mathrm{~mm}$ long, $1.4 \mathrm{~mm}$ wide. Petals obliquely elliptic, rounded and apiculate at apex, $1.7 \mathrm{~mm}$ long, $0.9 \mathrm{~mm}$ wide. Lip 3-lobed, subreniform-flabellate, 1.6 $\mathrm{mm}$ long, $2.5 \mathrm{~mm}$ wide; the lateral lobes obliquely elliptic, broadly rounded at apex, erect and surrounding the column in natural position; the midlobe transversally elliptic to subquadrate, apiculate, with minutely crenulate margins. Column short, terete, slightly arcuate, $1.2 \mathrm{~mm}$ long. Pollinia 6 , on a short caudicle. Anther cap subcordate, cucullate, 2-celled. 

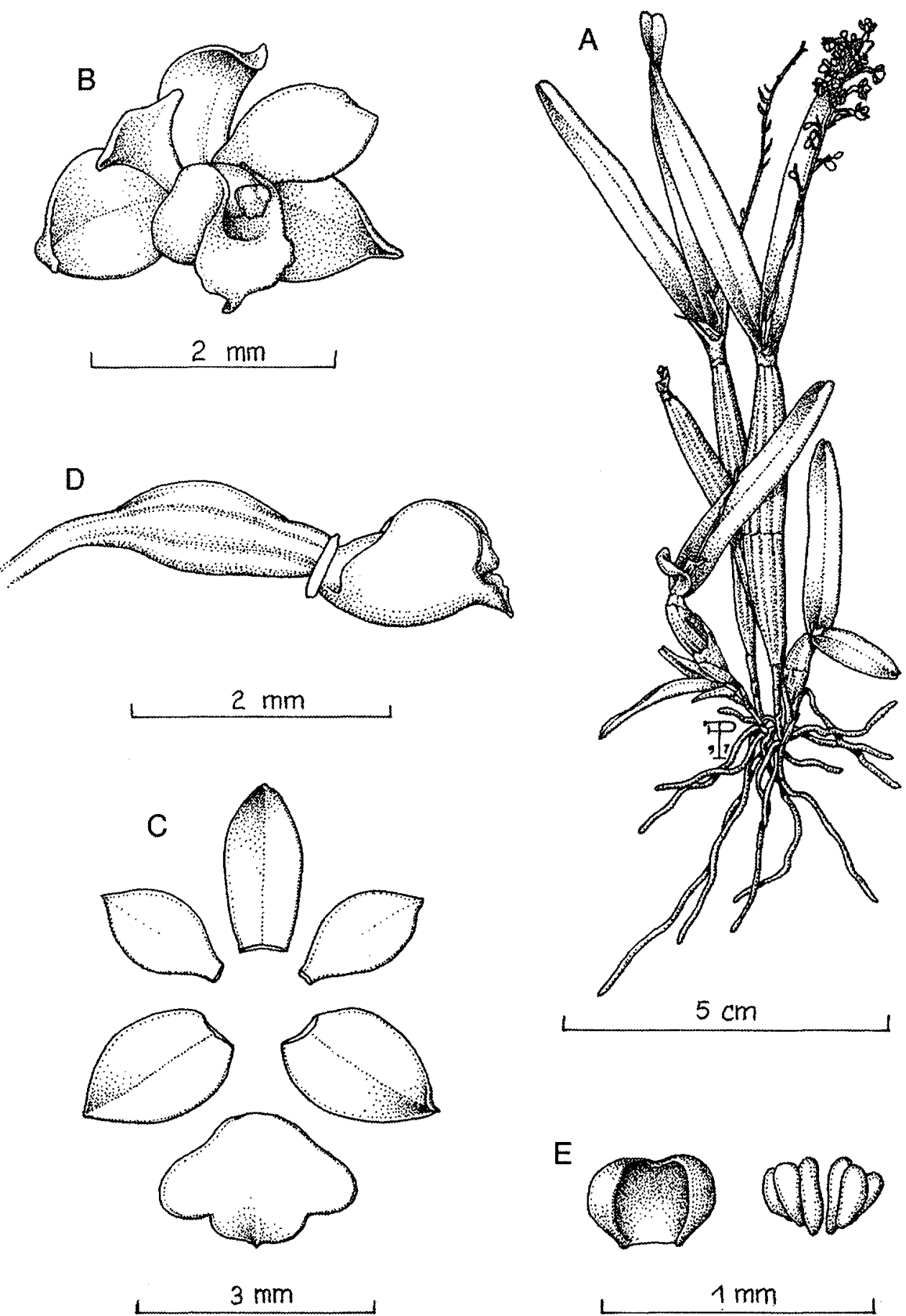

Fig. 34. Scaphyglottis micrantha (Lindl.) Ames \& Correll. A - Habit. B - Flower. C - Dissected perianth. D - Column and lip, lateral view. E - Operculum and pollinaria. Illustration voucher: F. Pupulin 377. 
Distribution: A Central American species distributed from Guatemala to Panama. Widespread in Costa Rica.

Parque Nacional Manuel Antonio: Plants were found as epiphyte on Hymenaea courbaril (guapinol) in disturbed primary forest. The species is occasional at PNMA.

Phenology: flowering recorded in July.

2. Scaphyglottis prolifera Cogn., Mart. Fl. Bras. 3(5): 15. 1898. Scaphyglotits cuneata Schltr., Beih. Bot. Centralbl. 36: 398. 1918. Tetragamestus gracilis Schltr., Beih. Bot. Centralbl. 36: 400. 1918. Scaphyglottis gracilis (Schltr.) Schltr., Fedde Rep. Sp. Nov. Beih. 19: 28. 1923. Scaphyglottis werklei Schltr., Fedde Rep. Sp. Nov. Beih. 19: 28. 1923. Ponera mapiriensis Krzl., Fedde Rep. Sp. Nov. Beih. 25: 22. 1928. (Fig. 35).

Plant epiphytic, cespitose, ascending, to about $20 \mathrm{~cm}$ tall, with pseudobulbous, usually superimposed stems. Roots filiform, slender, glabrous, emerging from the rhizome or from the insertion of new growths at the apex of old pseudobulbs. Pseudobulbs linear, terete, sometimes slightly attenuate at both the apices, to $10 \mathrm{~cm}$ long, $0.4 \mathrm{~cm}$ wide, diphyllous; two new, shorter pseudobulbs usually develop the next year at the apex of old pseudobulbs, emerging from short, imbricating, papyraceos sheaths. Leaves linear-elliptic, subcoriaceous, obliquely retuse, to $4.5 \mathrm{~cm}$ long, $0.5 \mathrm{~cm}$ wide. Inflorescence terminal at the apex of each internode of the stem, a single to few-flowered fascicle; peduncle subtended by several, imbricating, scarious sheaths. Ovaries pedicellate, linear-clavate. Flowers very small, with greenish sepals and petals, the lip white striped with purple and purple-brown anther. Dorsal sepal linear-elliptic, acute, slightly concave toward the apex, to $5 \mathrm{~mm}$ long, 2.5 $\mathrm{mm}$ wide. Lateral sepals obliquely elliptic, acute to obtuse, $6 \mathrm{~mm}$ long, $3 \mathrm{~mm}$ wide. Petals ligulate, rounded and apiculate at apex, $4 \mathrm{~mm}$ long, $1 \mathrm{~mm}$ wide. Lip spathulate-flabellate, emarginate, with a short apicule, slightly concave toward the base, reflexed at apex, 6 $\mathrm{mm}$ long, $3.5 \mathrm{~mm}$ wide. Column terete, provided at the base with a hole to enter the pedicellate spur, about $3 \mathrm{~mm}$ long. Pollinia 4 , on two short, bifid caudicles. Anther cap rounded, cucullate, 4-celled.

Distribution: A widespread species distributed from lowlands to about $1,000 \mathrm{~m}$ from Guatemala to Bolivia and Peru.

Parque Nacional Manuel Antonio: Plants were found as common epiphyte on Citrus spp. in orchards close to the park. It has not yet been reported from PNMA, where it should be regarded as a rare species.

Phenology: flowering occurs from November to February.

3. Scaphyglottis stellata Lindl., Bot. Reg. n.s. 12: misc. 60. 1839. Ponera amethystina Rchb.f., Saunders Ref. Bot. 2: t. 93. 1869. Scaphyglottis amethystina (Rchb.f.) Schltr., Beih. Bot. Centralbl. 36 (2): 456. 1918. Scaphyglottis brachiata Schltr., Fedde Rep. Sp. Nov. Beih. 9: 432. 1911. (Fig. 36).

Plant epiphytic, cespitose, erect to pendent, to about $40 \mathrm{~cm}$ tall, with pseudobulbous, usually superimposed segments. Roots filiform, slender, glabrous, emerging from the rhizome or at the connection of old and new pseudobulbs. Pseudobulbs fusiform, stipitate, to $12 \mathrm{~cm}$ long, $0.5 \mathrm{~cm}$ wide, diphyllous, each pseudobulb usually bearing a single new pseudobulb at apex the next year, emerging from imbricating, papyraceos sheaths. Leaves linear-lanceolate to narrowly elliptic, obliquely retuse, to $12 \mathrm{~cm}$ long, $0.8 \mathrm{~cm}$ wide. Inflorescence a few-flowered fascicle born at the apex of each internode of the stem. Ovaries pedicellate, linear. Flowers small, with white sepals and petals, the lip rose-purple striped with purple; column and anther deep purple. Dorsal sepal lanceolate-elliptic, acute, slightly concave toward the apex, $7 \mathrm{~mm}$ long, $2.5 \mathrm{~mm}$ wide. Lateral sepals connate at the base, forming a short mentum, obliquely linearlanceolate, acute, $8 \mathrm{~mm}$ long, $2.5 \mathrm{~mm}$ wide. Petals ligulate, slightly constricted toward the apex, then rounded and apiculate, $7 \mathrm{~mm}$ long, 

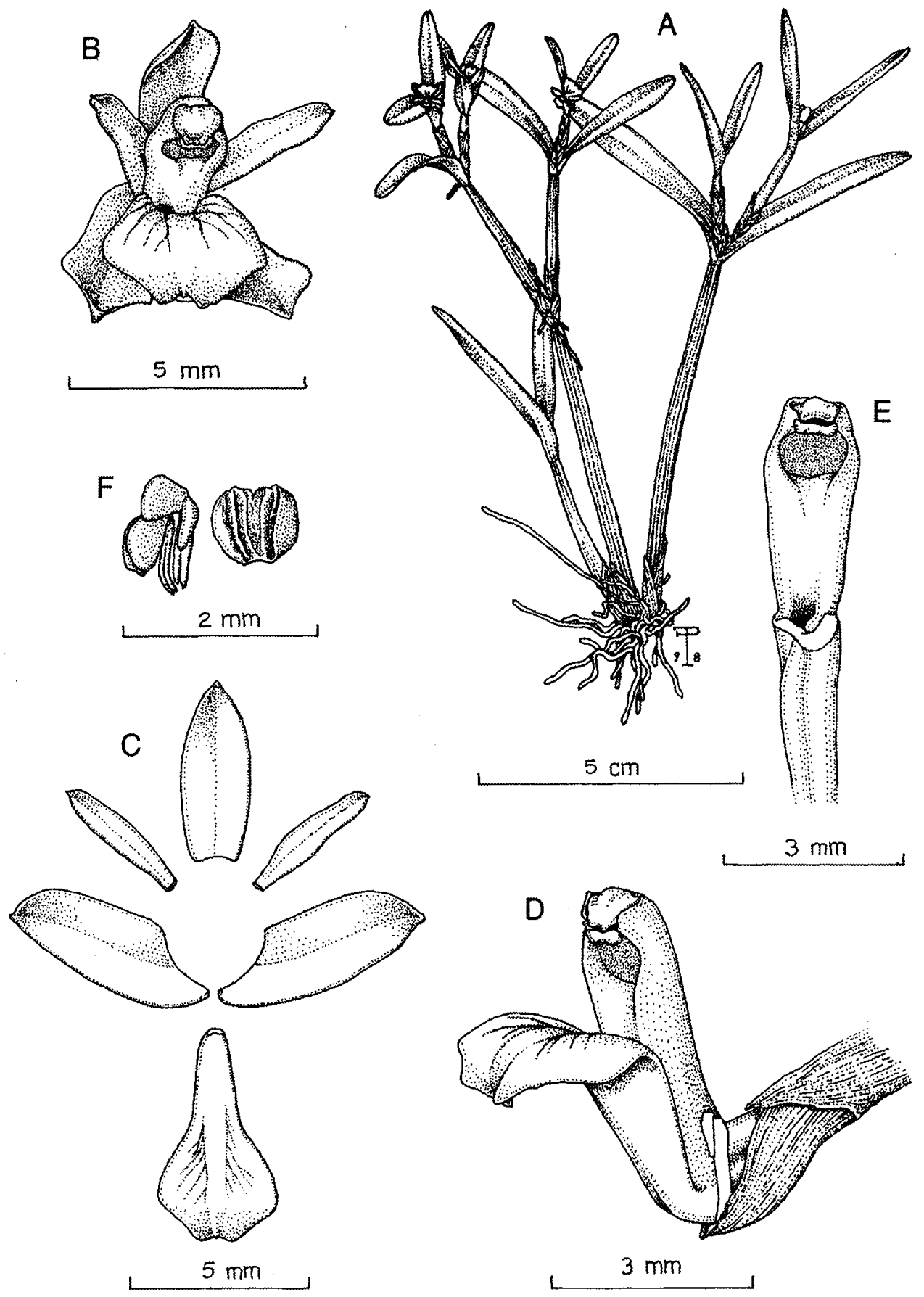

Fig. 35. Scaphyglottis prolifera Cogn. A - Habit. B - Flower. C - Dissected perianth. D - Column and lip, lateral view. E Column, ventral view. F - Pollinaria and operculum. Illustration voucher: F. Pupulin 471. 

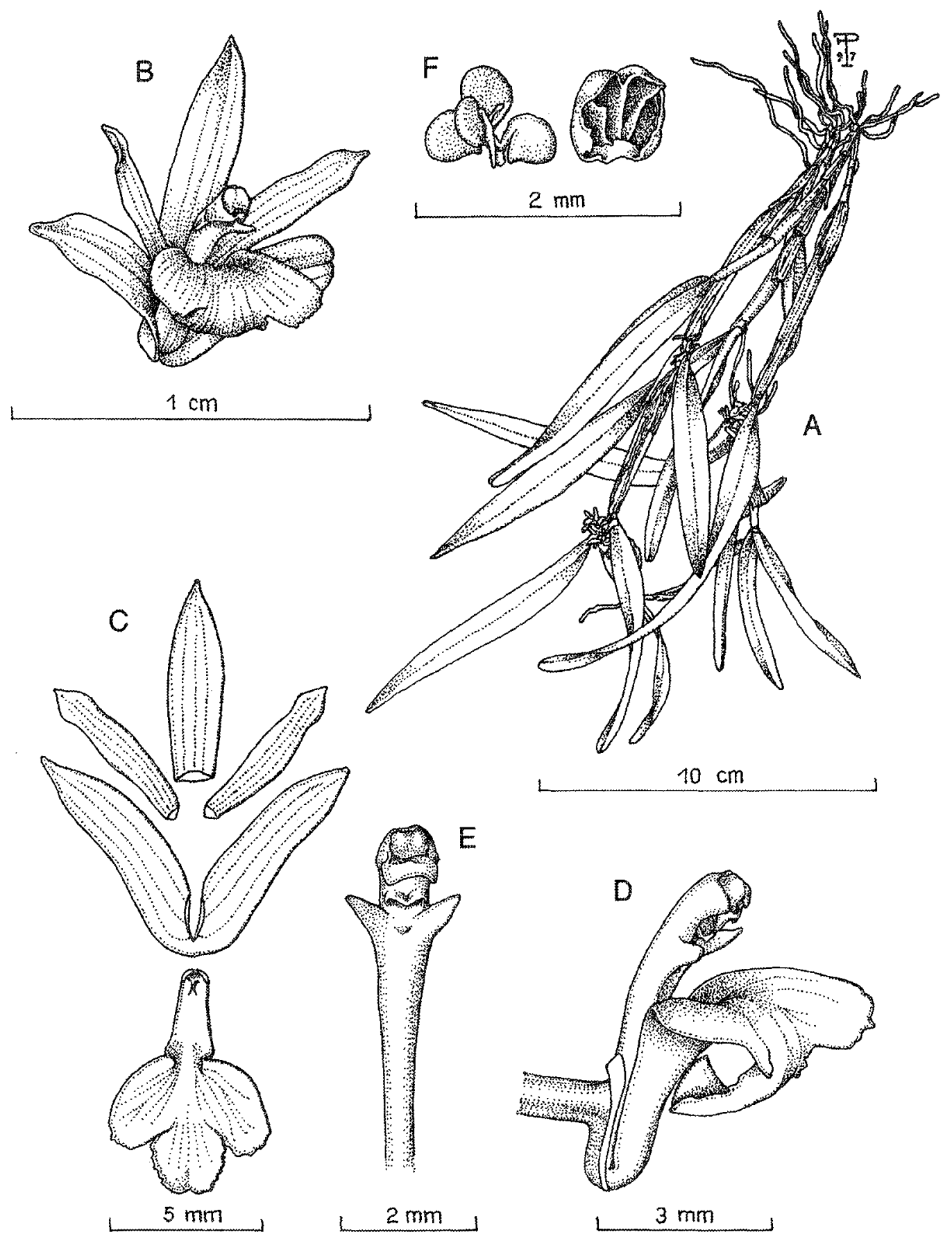

Fig. 36. Scaphyglottis stellata Lindl. A - Habit. B - Flower. C - Dissected perianth. D - Column and lip, lateral view. E Column, ventral view. F - Pollinaria and operculum.. Illustration voucher: F. Pupulin 300. 
$1.5 \mathrm{~mm}$ wide. Lip clawed, the blade 3-lobed, obovate-flabellate; lateral lobes large, rounded, erose at apex, inserted at the middle of the lip; midlobe subquadrate, obtuse to emarginate; entire lip $7 \mathrm{~mm}$ long, $5 \mathrm{~mm}$ wide between the lateral lobes. Column terete, slightly arcuate, with two narrowly triangular stelidiar arms toward the apex, $3 \mathrm{~mm}$ long. Pollinia 4 , on short bifid caudicles. Anther cap cucullate, rounded, 4-celled.

Distribution: A common species in lowlands in Costa Rica and Panama to Guianas and Bolivia.

Parque Nacional Manuel Antonio: Plants of Scaphyglottis stellata are common epiphytes in all types of vegetation at the Park, where they often form big clumps of many stems, usually pendent in mature specimens. It is a very common species at PNMA.

Phenology: flowering occurs from October to January.

\section{SOBRALIA Poepp. \& Endl.}

Terrestrial or epiphytic, small or large herbs, with foliaceous, reed-like stem. Leaves sessile, pergameneous, plicate. Inflorescence a terminal raceme, often 1-flowered. Flowers usually large, fugaceous. Sepals and petals subequal, sometimes shortly connivent at the base, spreading, the petals usually broader than sepals; lip not clawed, entire or 3-lobed, usually concave, the basal margins enfolding the column, the disc smooth or lamellate, usually with a inconspicuous to conspicuous callus at the base. Column elongate, usually ventrally provided with a strong keel, footless, anther incumbent. Pollinia 8, granular or subceraceous.

A neotropical genus of about 100 species, widespread from Mexico to South America, and the West Indies.

1. Sobralia decora Batem., Orch. Mex. \& Guat. t. 26. 1841. (Fig. 37).

Plant epiphytic or rarely terrestrial, erect to pendent, to about $2 \mathrm{~m}$ tall. Stem slender, covered with amplexicaul leaf-sheaths, sometimes branched, lepidote to slightly furfurescent. Roots fleshy, glabre. Leaves plicate-veined, lanceolate to lanceolate-ovate, acuminate, coriaceous, to about $15 \mathrm{~cm}$ long, 3$5 \mathrm{~cm}$ wide. Inflorescence apical, sessile, a 1flowered raceme. Flowers large, not completely spreading, rose-purple with darker lip. Sepals free, more or less reflexed at the tip. Dorsal sepal lanceolate, acute, slightly concave, about $6 \mathrm{~cm}$ long, $1.6 \mathrm{~cm}$ wide. Lateral sepals obliquely lanceolate, acute, concave toward the apex, $6 \mathrm{~cm}$ long, $1.4 \mathrm{~cm}$ wide. Petals elliptic-lanceolate, acute, $5.7 \mathrm{~cm}$ long, $2.2 \mathrm{~cm}$ wide. Lip obovate, obtuse to minutely retuse, deeply concave, the basal margins forming a tube enclasping the column, the apex deflexed, with slightly crenulate margins, $6.5 \mathrm{~cm}$ long, $3.6 \mathrm{~cm}$ wide; callus at the base of the lip formed by two low, slender, divergent carines. Column elongated, subterete, slender, abaxially keeled, to $3.5 \mathrm{~cm}$ long, with two introrse teeth at apex. Pollinia 8 , subceraceous. Anther cap cucullate, bifid at the base, about $3 \mathrm{~mm}$ long.

Distribution: A relatively common species in lowlands from Mexico to Panama.

Parque Nacional Manuel Antonio: Stobralia decora is known from a few plots at PNMA, where it is usually restricted as epiphyte to old trunks and large branches in primary or disturbed primary forest. The species is occasional at PNMA.

Phenology: flowering recorded in December.

\section{STENORRHYNCHOS L.C. Rich. ex} Spreng.

Terrestrial or epiphytic herbs with or without leaves at flowering, with basal leaves. Leaves short stalked, lanceolate, deciduous. Inflorescence erect, a usually dense raceme with colored bracts, many-flowered. Flowers relatively large. Sepals and petals subequal, the connivent bases of sepals forming a tube, spreading at apex; lip not clawed, the margins 

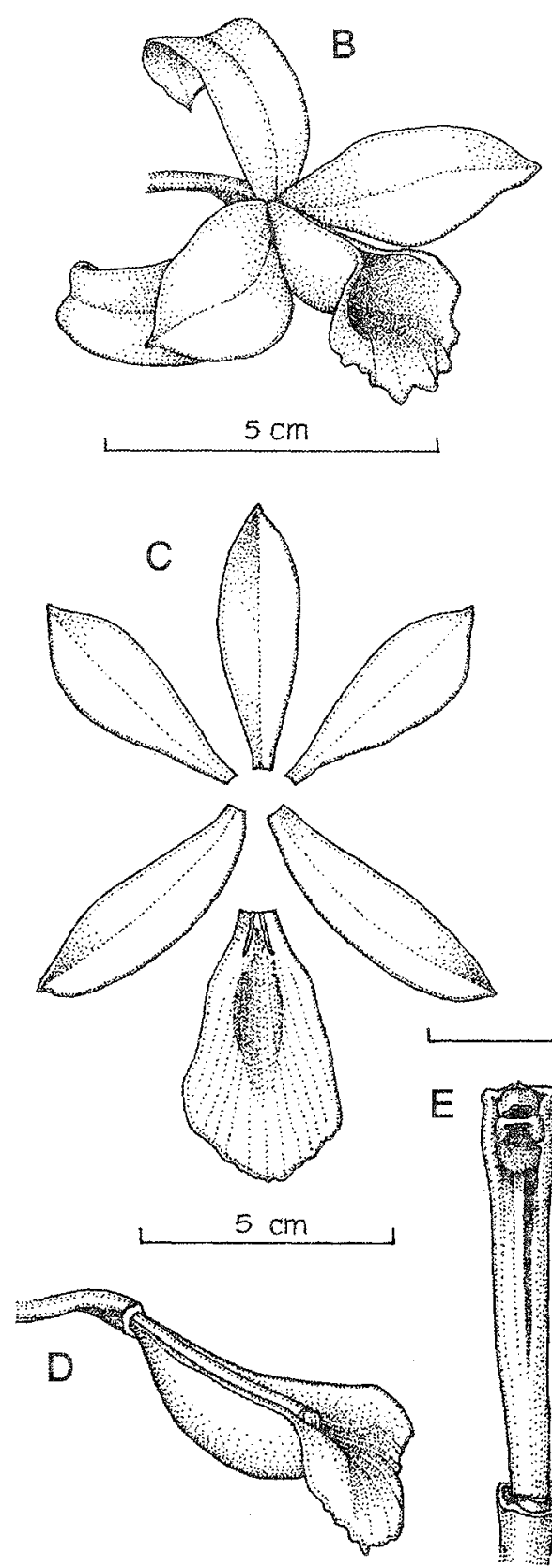

$50 \mathrm{~cm}$

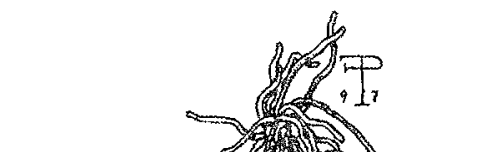


thickened at the base, with or without a constriction in the middle. Column massive, provided with a long foot, anther dorsal. Pollinia 2, powdery.

A small neotropical genus of some 3 species, widespread from Florida to Argentina, and the West Indies.

\section{Stenorrhynchos lanceolatum (Aubl.)}

L.C. Rich. ex Spreng., Syst Veg. 3: 710. 1826. Limodorum lanceolatum Aubl., Pl. Guian. 2: 821. 1775. Satyrium orchioides Sw. Prodr. Veg. Ind. Occ. 118. 1788. Neottia lanceolata (Aubl.) Willd., Sp. Pl. 4: 75. 1805. Spiranthes orchioides (Sw.) A. Rich. in Sagra, Hist. Fis. Pol. Nat. Cuba pt. 2, 11 [Bot.]: 252. 1850. Gyrostachys lanceolata (Aubl.) O. Ktze., Rev. Gen. Pl. 2: 664. 1891. Spiranthes jaliscana S. Wats., Proc. Amer. Acad. 26: 153. 1891. Spiranthes lanceolata (Aubl.) Leon, Contr. Ocas. Mus. Hist. Nat. Col. de la Salle, Acta 8: 385. 1946. Sacoila lanceolata (Aubl.) Garay, Leafl. Bot. Mus. Harvard Univ. 28: 352. 1982. (Fig. 38).

Plant terrestrial, erect, to about $30 \mathrm{~cm}$ tall, with basal, soft, herbaceous leaves, leafless at flowering stage, the stem enveloped by several amplexicaul bracts. Roots fleshy, clustered. Leaves 3-6, in a basal rosette, membranaceous, elliptic, $15-19 \mathrm{~cm}$ long, 2-3.5 $\mathrm{cm}$ wide. Inflorescence a congested, pubescent, many-flowered raceme to $50 \mathrm{~cm}$ long, with attenuate bracts. Flowers small, not completely spreading, pubescent on the external surface, rose-orange with white to pale rose lip. Sepals more or less connivent, spreading at the tip. Dorsal sepal lanceolate, acute, dorsally pubescent, about $20 \mathrm{~mm}$ long, 6 $\mathrm{mm}$ wide. Lateral sepals lanceolate, acute, dorsally pubescent, the base decurrent on the ovary producing an obtuse mentum, $23 \mathrm{~mm}$ long, $4.5 \mathrm{~mm}$ wide. Petals linear-elliptic to lanceolate, falcate, acute, $18 \mathrm{~mm}$ long, $4 \mathrm{~mm}$ wide, coherent to the dorsal sepal. Lip lanceolate, acute to obtuse, the apex deflexed, $23 \mathrm{~mm}$ long, $7 \mathrm{~mm}$ wide, the margins erect, fleshy, enclosing the column. Column wide basally, with an acuminate rostellum, to $6 \mathrm{~mm}$ long. Pollinia 2, narrowly pyriform, on a ligulate viscidium enveloping the rostellum. Anther cap acutely triangular, persistent, about $3 \mathrm{~mm}$ long.

Distribution: A widespread species distributed throughout tropical America.

Parque Nacional Manuel Antonio: Stenorrhynchos lanceolatum is known from a single collection at Jardín Gaia, not more than $3 \mathrm{~km}$ west of the park along the road to Quepos. Here a small population was found in rocky soil in secondary vegetation. The species should be regarded as rare at PNMA.

Phenology: flowering recorded in November to December.

\section{TRIGONIDIUM Lindl.}

Cespitose, epiphytic, erect to scandent herbs with sulcate pseudobulbs, 2- to 5-foliate at apex. Leaves conduplicate, linear, subcoriaceous, persistent. Inflorescence a simple, short to usually elongate raceme from the bases of pseudobulbs, 1-flowered. Flowers relatively large. Sepals subequal, the bases connivent forming a tube, the apex spreading; petals smaller than sepals, with an apical, glossy callus; lip 3-lobed, the lateral lobes erect, the midlobe thickened, the disc with a ligular callus. Column short, semiterete, footless, with terminal, incumbent anther. Pollinia 4, waxy.

A small neotropical genus of some 10 species, ranging from Mexico to Brazil.

1. Trigonidium egertonianum Batem. ex Lindl., Bot. Reg. n.s. 1: Misc. 73. 1838. Trigonidium seemanni Rchb.f., Seem. Bot. Voy. Herald 214. 1854. (Fig. 39).

Plant epiphytic, cespitose, forming large clumps. Roots fleshy, glabrous. Pseudobulbs ovate, somewhat laterally compressed, sulcate, to $3.5 \mathrm{~cm}$ long, about $3.2 \mathrm{~cm}$ wide, basally covered by 2-3 papyraceous sheaths, bifoliate at apex (rarely monophyllous). Leaves narrowly oblanceolate to linear, arching, acute, to about $30 \mathrm{~cm}$ long, $1.3-2 \mathrm{~cm}$ wide. 

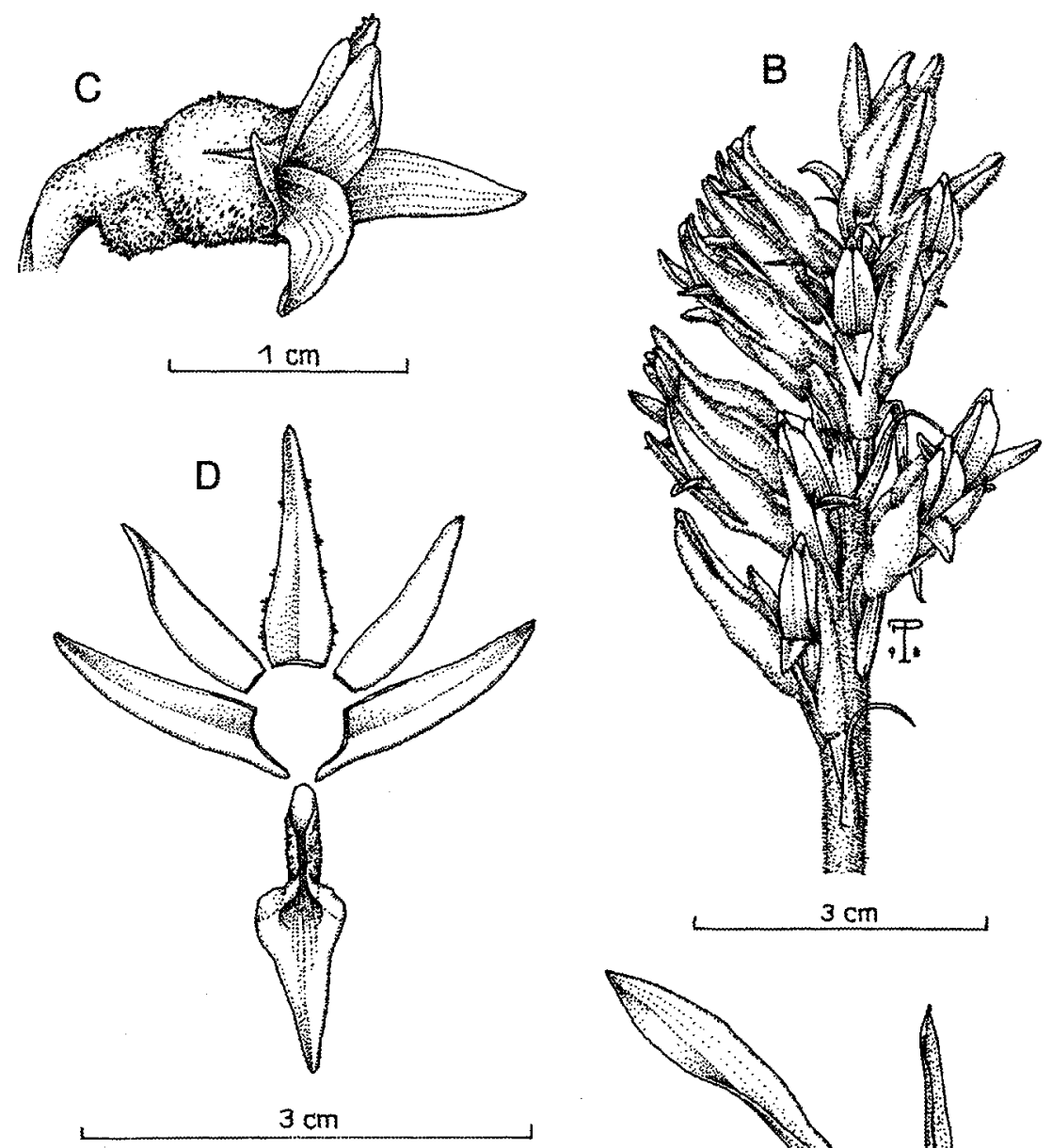

$\mathrm{F}$
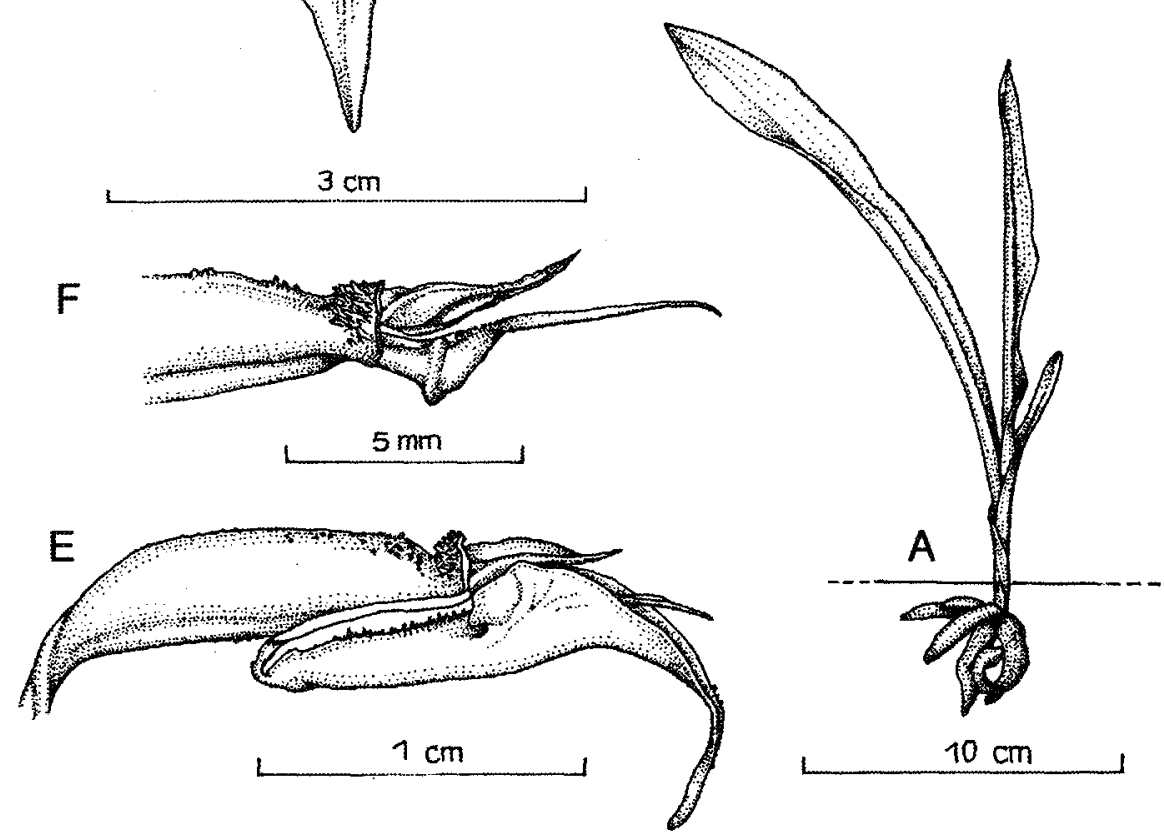

Fig. 38. Stenorrhynchus lanceolatum (Aubl.) L.C. Rich. ex Spreng. A - Habit. B - Inflorescence. C - Flower. D - Dissected perianth. E - Column and lip, lateral view. F - Column, lateral view (pollinarium removed). G - Operculum and pollinarium. Illustration voucher: F. Pupulin 356. 


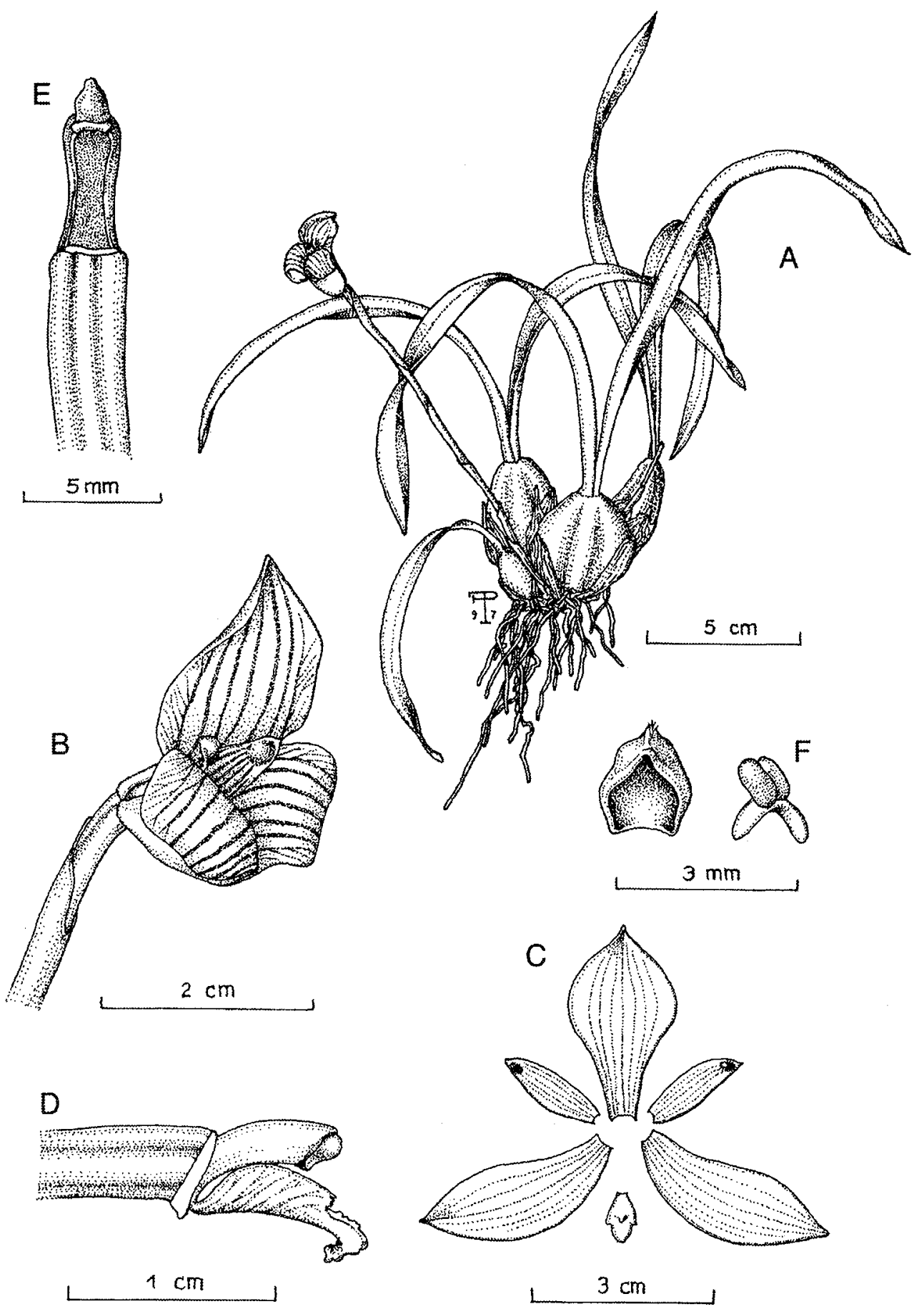

Fig. 39. Trigonidium egertonianum Batem. ex Lindl. A - Habit. B - Flower. C - Dissected perianth. D - Column and lip, lateral view. E - Column, ventral view. F - Operculum and pollinarium. Illustration voucher: F. Pupulin 368. 
Inflorescences basal, erect, slender, singleflowered scapes to $20 \mathrm{~cm}$ long, covered by many closely appressed, tubular, papyraceous sheaths. Flowers rather showy, pale yellow to pale orange striped and reticulated with purple, the petals provided with metallic blue to mauve blotch near the apex. Sepals free, appressed toward the base forming a tube, then abruptly expanded and reflexed at apex. Dorsal sepal shortly unguiculate, ellipticoblanceolate, acute, $3.3 \mathrm{~cm}$ long, $1.8 \mathrm{~cm}$ wide. Lateral sepals obliquely elliptic-lanceolate, acute, $3.4 \mathrm{~cm}$ long, $1.3 \mathrm{~cm}$ wide. Petals lanceolate, acute, about $1.8 \mathrm{~cm}$ long, $0.6 \mathrm{~cm}$ wide. Lip 3-lobed, articulate with the base of the column; lateral lobes erect and parallel to the column, acute; the midlobe ovate, acute to obtuse, rather fleshy, verrucose; disc with a fleshy ligulate callus as long as the lateral lobes; entire lip $0.8 \mathrm{~cm}$ long, $5 \mathrm{~mm}$ wide between lateral lobes. Column subterete, about $7 \mathrm{~mm}$ long. Pollinia 2, elliptic, on a saddle shaped caudicle. Anther cap cucullate, keeled.

Distribution: A widespread species from Mexico to Panama and Colombia, very common in Central American lowlands.

Parque Nacional Manuel Antonio: The species is usually restricted to primary and secondary mature forest, where it establishes itself in partial shade on trunks and large limbs covered with bryophytes. Though common through its range, the species is only occasional at PNMA.

Phenology: flowering occurs from November to February.

\section{TRIZEUXIS Lindl.}

Cespitose, epiphytic herbs with short, distichously foliaceous stem, the leaves arranged in a fan envolving a small pseudobulb, 1-foliate at apex. Leaves falcate, laterally flattened, coriaceous. Inflorescence a pendent, paniculate raceme from the base of pseudoblb, many-flowered. Flowers subglobose, small. Sepals dissimilar, the dorsal deeply concave, the laterals connate nearly to the apex, forming a mentum at the base; petals about as long as sepals; lip shortly clawed, 3lobed, articulated with the column base, the apex fleshy. Column erect, subcylindricclavate, with terminal, incumbent anther. Pollinia 2, waxy.

Probably a monotypic neotropical genus, widespread from Costa Rica to Trinidad, Brazil, Bolivia and Peru.

1. Trizeuxis falcata Lindl., Collect. Bot. t. 2. 1823. Trizeuxis andina Schltr., Repert. Sp. Nov. 10: 52. 1922. (Fig. 40).

Plant epiphytic, small, erect, to about 5 $\mathrm{cm}$ tall, with a short, distichously foliaceous stem. Roots flexuous, glabre. Pseudobulbs rounded to subquadrate, to $5 \mathrm{~mm}$ long, about 4 $\mathrm{mm}$ wide, basally covered by $2-3$ imbricating leafy sheaths, monophyllous. Leaf fleshy, laterally flattened, falcate to gladiate, acuminate, $1-3.5 \mathrm{~cm}$ long, $0.2-0.4 \mathrm{~cm}$ wide, articulate to the basal sheaths and arranged like a fan. Inflorescence a basal, arcuate to pendent, slender, paniculate raceme to $4 \mathrm{~cm}$ long, the lateral subcapitate branches about 2 $\mathrm{cm}$ long, many-flowered. Flowers very small, subglobose, greenish yellow to pale yellow with yellow to orange lip. Dorsal sepal ovate, retuse to emarginate, deeply concave, partially connate with the petals, $1.5 \mathrm{~mm}$ long, $1.2 \mathrm{~mm}$ wide. Lateral sepals connate to nearly the apex to produce a obovate, bifid synsepalum, $1.9 \mathrm{~mm}$ long, $1.5 \mathrm{~mm}$ wide. Petals ellipticovate, obtuse, about $2.5 \mathrm{~mm}$ long, $1.2 \mathrm{~mm}$ wide. Lip 3-lobed, lanceolate, acute, concave at the base, with erect lateral margins enclosing the column, the apex fleshy, about $2.5 \mathrm{~mm}$ long. Column short, stout, subterete, dilated at apex, to $1 \mathrm{~mm}$ long. Pollinia 2, pyriform, on a large stipe. Anther cap cucullate, very large relatively to the column, about $1 \mathrm{~mm}$ long.

Distribution: A widespread species in South America to Brazil and Bolivia, reaching in Costa Rica its northern distributional limit.

Parque Nacional Manuel Antonio: The species is known only from bushes and 


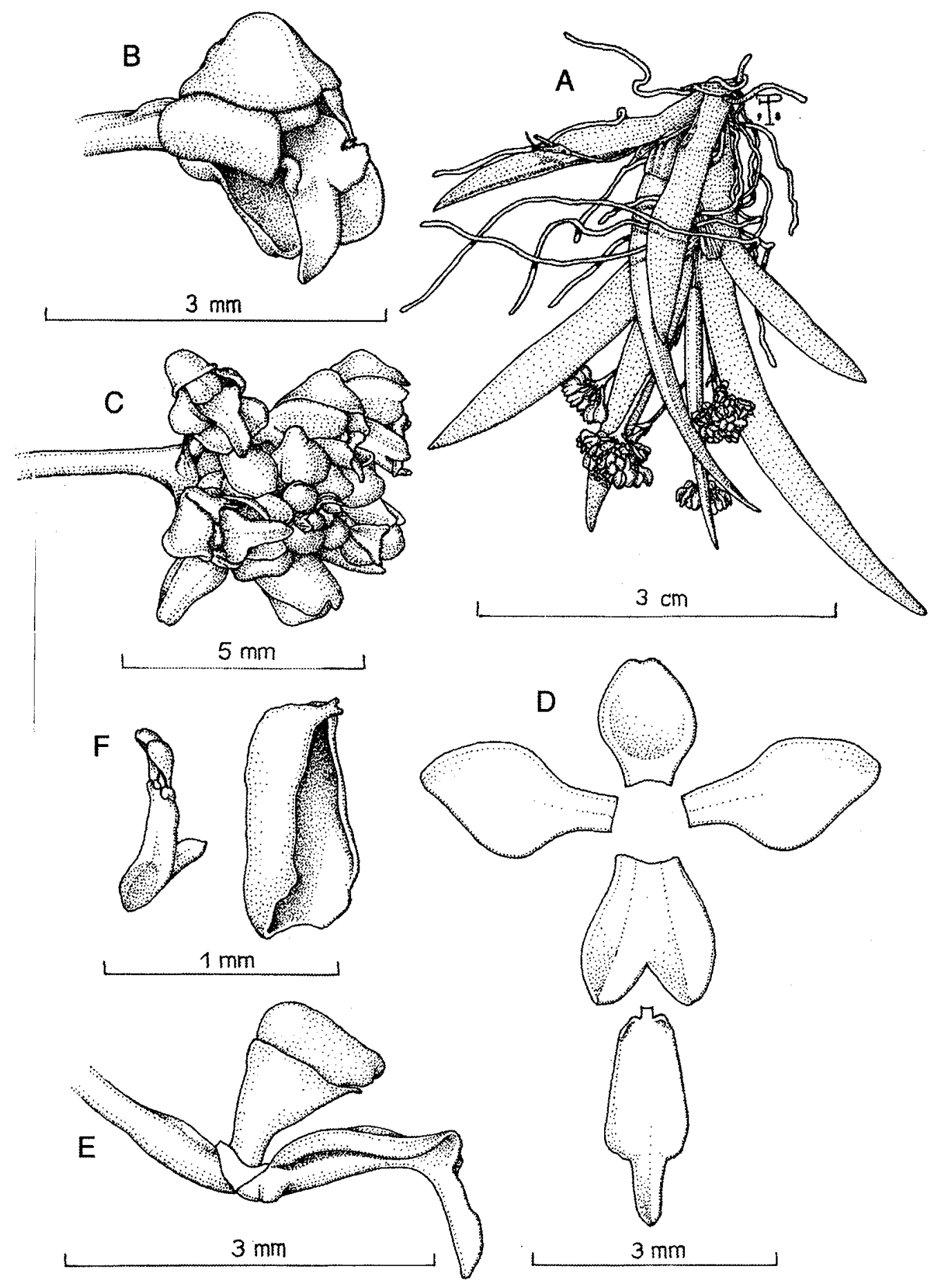

Fig. 40. Trizeuxis falcata Lindl. A - Habit. B - Flower. C - Apex of inflorescence. D - Dissected perianth. E - Column and lip, lateral view. F - Pollinarium and operculum. Illustration voucher: F. Pupulin 473. 
orchards outside the park, about $1 \mathrm{~km}$ west the border of PNMA along the road to Naranjito. Though usually common through its range, Trizeuxis falcata should be regarded as rare at PNMA.

Phenology: flowering most of the year. In Ecuador the species is pollinated by small bees of the genus Trigona (Dodson \& MarmolDodson 1980).

\section{VANILLA Sw.}

Epiphytic, scandent, leafy or aphyllous herbs, with elongate, erect to pendent, often branched stems. Leaves conduplicate, coriaceous or fleshy, persistent, sessile or with a short petiole. Inflorescence a short raceme from the axils of the leaves, usually with many flowers produced successively. Flowers usually large. Sepals and petals subequal, spreading, free; the lateral sepals sometimes shortly connate; lip clawed, simple or 3-lobed, the claw adnate to the column, the lateral lobes erect to enfold the colum, the midlobe spreading or reflexed, usually provided with longitudinal keels or lines of papillae and with a tuft of hairs at the base. Column elongate, without a foot, wingless, with incumbent anther. Pollinia granular.

The only member of the Orchidaceae having a truly commercial value, Vanilla is a pantropical genus of about 100 species widely cultivated for the flavouring extract from its seed pods.

1. Vanilla pompona Schiede, Linnaea 4: 573, 1829. Vanilla pompona Lindl., Gen. \& Sp. Orch. Pl. 437. 1840. Vanilla pittieri Schltr., Fedde Rep. Spec. Nov. 3: 106. 1906.

Plant emiepiphytic, large, scandent, to $10 \mathrm{~m}$ tall, with a large, branched, foliaceous stem. Roots glabre. Leaves variable, from narrowly elliptic to lanceolate-ovate, fleshy to coriaceous, acute or obtuse, $10-30 \mathrm{~cm}$ long, $3-8.5 \mathrm{~cm}$ wide, articulate to the terete stem. Inflorescences lateral, produced form the axil of the leaves, erect to arcuate, stout, a raceme to about $15 \mathrm{~cm}$ long, manyflowered; bracts lanceolate to ovate, obtuse, cucullate, $1 \mathrm{~cm}$ long. Flowers large and fleshy, greenish yellow to pale yellow with white lip. Dorsal sepal linear elliptic to oblanceolate, acute to obtuse, concave, 7.5 $\mathrm{cm}$ long, $1.3 \mathrm{~cm}$ wide. Lateral sepals obliquely and narrowly oblanceolate, acute to obtuse, to about $8 \mathrm{~cm}$ long, $1.5 \mathrm{~cm}$ wide. Petals narrowly elliptic, obtuse to acute, about $7 \mathrm{~cm}$ long, $1.2 \mathrm{~cm}$ wide. Lip clawed, the isthmus adnate to the column, obovate to subrhombic, trumpet shaped, retuse to emarginate, concave at the base, crenulate toward the apex, the disc with a tuft of hairs, about $8.5 \mathrm{~cm}$ long, $3.5-4 \mathrm{~cm}$ wide toward the apex. Column subterete, slender, without a foot, slightly dilated at apex, to $6 \mathrm{~cm}$ long. Pollen mealy. Anther cap ventral, cucullate, about $7 \mathrm{~mm}$ long. Fruit a fusiform capsule (the "bean") about $15 \mathrm{~cm}$ long.

Distribution: A widespread species from Mexico to South America, often cultivated as ornamental and a source of flavouring.

Parque Nacional Manuel Antonio: Cultivated as an ornamental at Jardín Gaia, a few kilometers from the Park on the road to Quepos. Natural populations of this species are said to be found in the neighbouring remnants of primary forest. The species should be regarded as rare at PNMA.

Phenology: flowering occurs in March to April.

Excluded species. The following species were reported for PNMA (Bolaños et al. 1983), but no specimens are conserved in Costa Rican herbaria and actual plants were not found by the author either within the Park or in the neighbouring areas:

Bletia purpurea (Lam.) DC. Outside the study area this species was found just to rocky beachs in southern Pacific coast at Isla Virolín, Puntarenas (Poveda \& Gómez 4717, CR!).

Brassia caudata (L.) Lindl. No actual specimens of this taxon were observed from PNMA nor in museum collections. Claims for the existence of Brassia spp. has been reported 
(J.B. Garcia, pers. comm.), but due to the great tall of this species and the showy flowers, it is unikely it has escaped attention until now.

Cyrtopodium punctatum Lindl. This species is generally associated to dry, strongly seasonal vegetation, and its presence at PNMA is unlikely.

Chysis aurea (L.) Lindl. This species is not actually reported for Costa Rica.

Encyclia cordigera (H.B.K.) Dressler (as Epidendrum atropurpureum). This species is generally associated to seasonal vegetation and ecological conditions at PNMA are unlikely to meet species requirements.

E. ionophlebia (Rchb.f.) Dressler (as Epidendrum ionophlebium). E. ionophlebia is a species usually restricted to mountainous areas above 800 meters elevation, and its occurence at PNMA is unlikely. However, the presence in our area of members of Encyclia subgenus Osmophytum, like $E$. chacaoensis, is highly probable.

Laelia rubescens Lindl. Although this species has not been collected recently, undocumented records exist of early collections in the area surrounding the Park (J. B. García, pers. comm.).

Lockhartia acuta (Lindl.) Rchb.f. Reports of this species from Manuel Antonio are probably based on the misidentification of specimens pertaining to $L$. pandurata Pupulin.

L. pittieri Schltr. This species is restricted to the Atlantic (Caribbean) lowlands, and its presence at PNMA is unlikely.

Maxillaria alba (Hook.) Lindl. Due the large size of this species, it is unlikely it have been so long overlooked at PNMA.

M. planicola C. Schweinf. No specimens of this taxon were observed within the studied plots. No collections from the study area were found in Costa Rican herbaria. A very similar species has recently been described (Atwood 1995) from Monteverde and the Atlantic slopes of Volcán Barva.

$M$. uncata Lindl. Though no actual specimens of this taxon were found at PNMA or in the neighbouring areas, plants of $M$. uncata are usually small, and their presence may be easily overlooked.

Myrmecophyla tibicinis (Batem.) Rolfe (as Schomburgkia). Due to the large size of the plants of this species, it is unlikely that they have escaped attention by botanists and aficionados. No specimens were observed at any of the studied plots.

Mormodes igneum Lindl. No collections of this taxon from PNMA are known, but $M$. fractiflexa Rchb.f. has been collected from southernmost Peninsula de Osa (C. Skotak s.n., USJ!).

Oncidium ampliatum Lindl. Though this species is typical of deciduous forests (Janzen, 1983), an early report exists from Manuel Antonio area, where the species lived mixed with Laelia rubescens populations (J.B. García, pers. comm.).

Oncidium dichromatichum (as 0 . cabagrae Schltr.). This taxon is generally found from about 800 to 2500 meters above sea level, and its presence at PNMA is unlikely. It is likely the juvenile pseudobulbs of Aspasia epidendroides, blotched with purple, were misinterpreted as this species.

Psygmorchis pusilla (L.) Dodson \& Dressler (as Oncidium pusillum). Though common on disturbed vegetation and orchards, the presence of this species at PNMA has not yet been confirmed. It may be previous claims were based on observations of the similarly psygmoid Trizeuxis falcata.

Stanhopea pulla Rchb.f. This species is native from the Caribbean lowlands.

Stelis sp. Besides Pleurothallis corniculata and the diminutive $P$. lewisae, no other member of the Pleurothallidinae were found within the Park area.

Trichopilia maculata Rchb.f. The presence of this species at such low elevation is very unlikely.

\section{ACKNOWLEDGMENTS}

I am grateful to José Antonio Salazar Alvarez, Director of PNMA, for his courtesy 
and logistic support and to Delio Salazar Ribera, Servicio de Parques Nacionales, for his continuous help as a fieldguide during sampling and collection of botanical material. I am very much indebted to Dario Castelfranco, Director, Jardín Gaia Botanical Garden, for the many facilities and for his suggestions and critical comments during all stages of the work. Joaquín B. García shared with me his life-long acquaintenance with Costa Rican orchids, and Robert L. Dressler gave me his valuable advice for the determination of difficult taxa. This paper is dedicated to my daughters, Margherita and Carlotta, for whatever it cost us.

\section{REFERENCES}

Allen, P.A. 1952. The swan orchids, a revision of the genus Cychnoches. Orch. J. 1: 1-226.

Atwood, J. T. 1995. Two overlooked species of Maxillaria from Central America. Selbyana 16: 242-245.

Bolaños, R., R. Campos, M. Hammond, R. DuBois, C. Esquivel, L. Gómez, M. Hatziiolos, L. Moreira \& J. Mora. 1982. El Parque Nacional Manuel Antonio. Inventario Biologico terrestre y marino. Estudio oceanográfico y diseño paisajista. Centro Científico Tropical, San José, Costa Rica.

Boza, M. A. 1986. Parques Nacionales Costa Rica National Parks. Fundación de Parques Nacionales, Costa Rica. Incafo, Madrid.

Campos, J. (coordinator). 1983. Propuesta plan de manejo Parque Nacional Manuel Antonio. Resumen ejecutivo. FUNDEVI, Servicio de Parques Nacionales and Instituto Costarricense de Turismo, San José, Costa Rica.
Chase, M.W. 1987. Obligate twig epiphytism in the Oncidiinae and other neotropical orchids. Selbyana 10: 24-30.

Chase, M.W. \& J.S. Pippen. 1988. Seed morphology in the Oncidiinae and related subtribes. Syst. Bot. 13: 313323.

Dodson, C.H. \& P. Marmol-Dodson, 1980. Trizeuxis falcata, Icon. Pl. Trop. 4: sub pl. 350.

Dressler, R.L. 1966. Observations on orchids and euglossine bees in Panama and Costa Rica. Rev. Biol. Trop.

Dressler, R.L. 1993. Field guide to the orchids of Costa Rica and Panama. Comstock, Ithaca, New York.

Holdridge, L. R. 1982. Ecología (basada en zonas de vida). Instituto Interamericano de Cooperación para la Agricultura, San José, Costa Rica.

Janzen, D.H. (ed.) 1983. Costa Rican natural history. Chicago University, Chicago.

Mora-Retana, D. E. \& J. B. García. 1992. Lista actualizada de las orquídeas de Costa Rica (Orchidaceae). Brenesia 37: 79-124.

Rojas, M., G. Robitaille, J. R. Barborak, F. Carr, R. Morales, C. McFarland \& J. Calderón. 1983. Plan de manejo y desarrollo Parque Nacional Manuel Antonio. Centro Agronomico Tropical de Investigación y Enseñanza (CATIE), Turrialba, Costa Rica.

Tosi, J. 1969. Mapa ecológico de Costa Rica. Centro Científico Tropical, San José, Costa Rica.

Wong Reyes, G. 1990. Ecología del Mono Titi Saimiri oerstedi citrinellus en el Parque Nacional Manuel Antonio, Costa Rica. Tesis de Grado, Universidad Nacional, Heredia, Costa Rica. 